\title{
Deformation Characteristics and Time-Dependent Notch Sensitivity of Udimet 700 at Intermediate Temperatures
}

Final Report

DAVID J. WILSON

March 1974

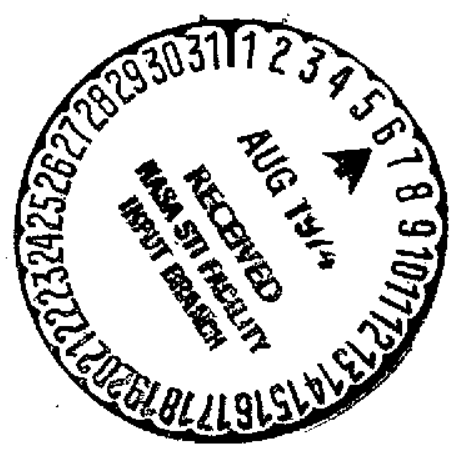

National Aeronautics and Space Administration Grant NGL-23-005-005 Washington, D.C.

\section{College of Engineering}

Department of Materials and Metallurgical Engineering 


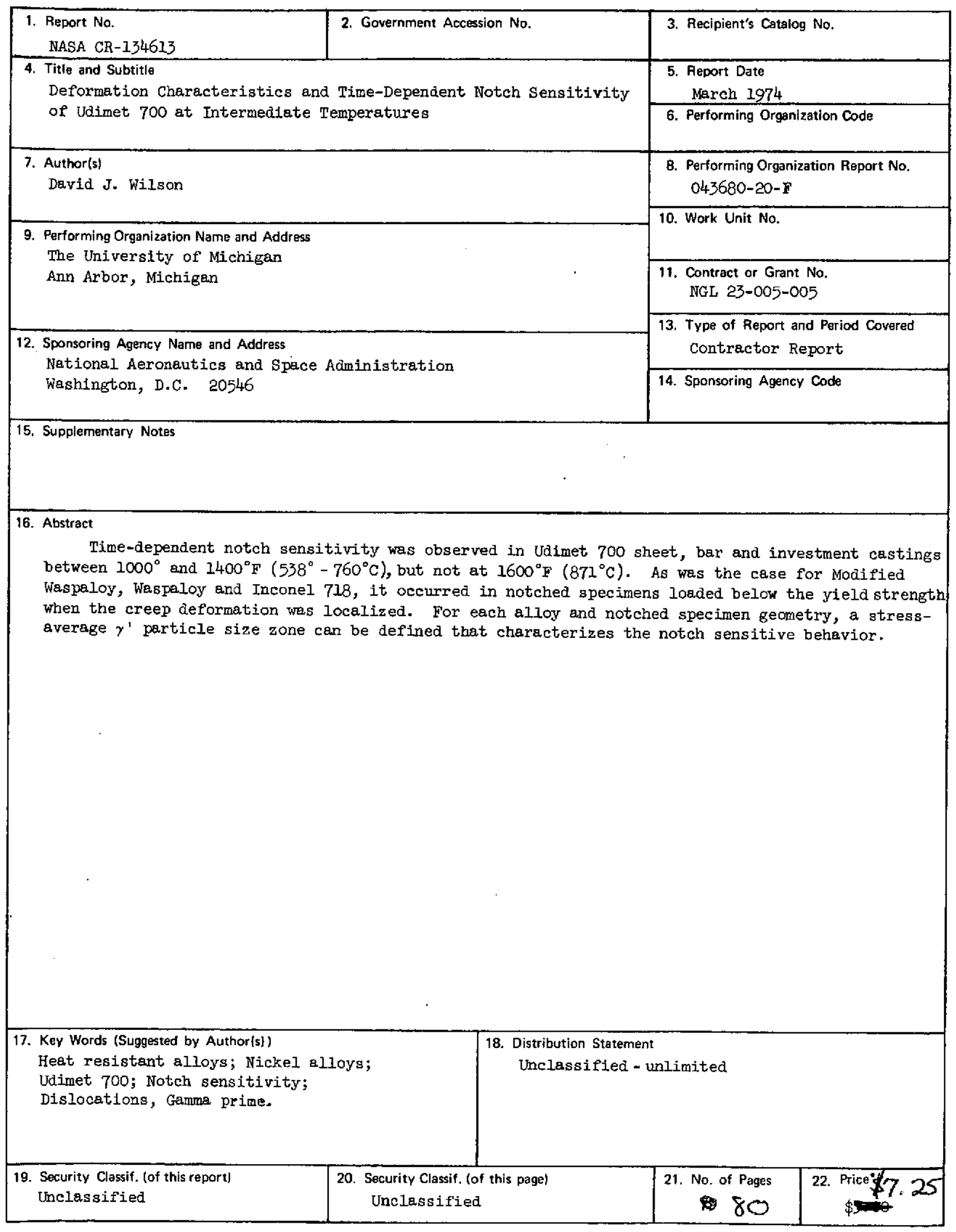

*For sale by the National Technical Information Service, Springfield, Virginia 22151 
TABLE OF CONTENTS

LIST OF TABLES

Page

iv

LIST OF FIGURES

v

INTRODUCTION

EXPERIMENTAL DETAIIS

MECHANICAL CHARACTERISTICS

Hardness

Tensile Characteristics at $1200^{\circ} \mathrm{F}\left(649^{\circ} \mathrm{C}\right)$

Creep-Rupture Strengths

MICROSTRUCTURAL FEATURES

Volume Fraction of Gamma Prime $\left(V_{f}\right)$

Gamma Prime Particle Size

Dislocation Structures

Sheet smooth specimens tensile tested at $1200^{\circ} \mathrm{F}\left(649^{\circ} \mathrm{C}\right)$

16

Creep-rupture tested sheet specimens

17

Creep-rupture tested bar and investment cast specimens

20

DISCUSS ION

21

Theoretical Considerations

21

Correlation of the Time-Dependent Notch Sensitivity with the Dislocation Mechanism

24

SUMMARY OF RESULTS 
Table

Page

I. Smooth and Edge-Notched $\left(\mathrm{K}_{\mathrm{t}}>20\right)$ Specimen Tensile and CreepRupture Properties at $1000^{\circ}$ to $1200^{\circ} \mathrm{F}\left(538^{\circ}-871^{\circ} \mathrm{C}\right)$ for $0.025-$ Inch $(0.64 \mathrm{~mm})$ Thick Udimet 700 sheet Solution Treated $1 / 2$ Hour at $2150^{\circ} \mathrm{F}\left(1177^{\circ} \mathrm{C}\right)$ and Aged

II. Smooth and Circumferential-Notched $\left(\mathrm{K}_{t}=6\right)$ Round specimen Tensile and Creep-Rupture Properties at $1000^{\circ}$ to $1800^{\circ} \mathrm{F}$ $\left(538^{\circ}-982^{\circ} \mathrm{C}\right)$ for $0.6-$ Inch $(1.5 \mathrm{~cm})$ Diameter Heat Treated Udimet 700 Bar

III. Smooth and Edge-Notched $\left(\mathrm{K}_{\mathrm{t}}=18\right)$ Specimen Tensile and CreepRupture Properties at $1000^{\circ}$ to $1600^{\circ} \mathrm{F}\left(538^{\circ}-871^{\circ} \mathrm{C}\right)$ for $0.09-$ Inch $(2.3 \mathrm{~mm})$ Thick Sections of Investment Cast Udimet 700 Solution Treated 4 Hours at $2150^{\circ} \mathrm{F}\left(1177^{\circ} \mathrm{C}\right)$ and Aged

IV. Gamma Prime Volume Fractions and Size Distributions for Udimet 700 
1. Larson-Miller parameter curves showing the time-temperature dependence of the mupture strengths of sheet Waspaloy heat treated $1 / 2$ hour at $1975^{\circ} \mathrm{F}\left(1079^{\circ} \mathrm{C}\right)$ plus 16 hours at $1400^{\circ} \mathrm{F}$ $\left(760^{\circ} \mathrm{C}\right)$ - Reference 1.

2. The effect of elevated temperature exposures on the diamond pyramid hardness of sheet Udimet 700 solution treated $1 / 2$ hour at $2150^{\circ} \mathrm{F}\left(1177^{\circ} \mathrm{C}\right)$.

3. Types of sheet specimens (all dimensions in inches).

4. Smooth and edge-notched $\left(K_{t}=18\right)$ investment cast specimens (all dimensions in inches).

5. Round test specimens from the wrought bar (all dimensions in inches).

6. Tensile characteristics of solution treated and aged Udimet 700 sheet at $1200^{\circ} \mathrm{F}\left(649^{\circ} \mathrm{C}\right)$ as a function of the average gamma prime particle size.

7. Larson-Miller parameter curves showing the time-temperature dependence of the smooth-specimen rupture strengths of sheet Udimet 700 solution treated at $2150^{\circ} \mathrm{F}\left(1.177^{\circ} \mathrm{C}\right)$ and aged.

8. Larson-Miller parameter curves showing the time-temperature dependence of the rupture strengths of sheet Udimet 700 solution treated and aged 3 hours at $1500^{\circ} \mathrm{F}\left(816^{\circ} \mathrm{C}\right)$.

9. Larson-Miller parameter curves showing the time-temperature dependence of the rupture strengths of sheet Udimet 700 solution treated and aged 24 hours at $1600^{\circ} \mathrm{F}\left(871^{\circ} \mathrm{C}\right)$.

10. Larson-Miller parameter curves showing the time-temperature dependence of the rupture strengths of sheet Udimet 700 solution treated and aged 48 hours at $1700^{\circ} \mathrm{F}\left(927^{\circ} \mathrm{C}\right)$.

11. Larson-Miller parameter curves showing the time-temperature dependence of the rupture strengths of sheet Udimet 700 solution treated and aged 4 hours at $1975^{\circ} \mathrm{F}\left(1079^{\circ} \mathrm{C}\right)$ plus 24 hours at $1550^{\circ} \mathrm{F}\left(843^{\circ} \mathrm{C}\right)$ plus 16 hours at $1400^{\circ} \mathrm{F}\left(760^{\circ} \mathrm{C}\right)$. 
LIST OF FIGURES (Continued)

Figure

Page

12. Larson-Miller parameter curves showing the time-temperature dependence of the rupture strengths of round smooth specimens of Udimet 700 bar solution treated at $2150^{\circ} \mathrm{F}\left(1177^{\circ} \mathrm{C}\right)$ and aged.

13. Iarson-Miller parameter curves showing the time-temperature dependence of the rupture strengths of Udimet 700 bar solution treated, air cooled, and aged 3 hours at $1500^{\circ} \mathrm{F}\left(816^{\circ} \mathrm{C}\right)$ and bar solution treated and water quenched.

14. Larson-Miller parameter curves of the rupture strengths of Udimet 700 bar solution treated and aged 24 hours at $1600^{\circ} \mathrm{F}$ $\left(871^{\circ} \mathrm{C}\right)$.

15. Larson-Miller parameter curves of the rupture strengths of Udimet 700 bar solution treated and aged 4 hours at $1975^{\circ} \mathrm{F}$ $\left(1079^{\circ} \mathrm{C}\right)$ plus 24 hours at $1550^{\circ} \mathrm{F}\left(843^{\circ} \mathrm{C}\right)$ plus 16 hours at $1400^{\circ} \mathrm{F}\left(760^{\circ} \mathrm{C}\right)$.

16. Iarson-Miller parameter curves showing the time-temperature dependence of the rupture strengths of smooth and edge-notched ("flat") specimens of investment-cast Udimet 700 solution treated and aged 3 hours at $1500^{\circ} \mathrm{F}\left(816^{\circ} \mathrm{C}\right)$.

17. Larson-Miller parameter curves of the rupture strengths of investment-cast Udimet 700 solution treated and aged 4 hours at $1975^{\circ} \mathrm{F}\left(1079^{\circ} \mathrm{C}\right)$ plus 24 hours at $1550^{\circ} \mathrm{F}\left(843^{\circ} \mathrm{C}\right)$ plus 16 hours at $1400^{\circ} \mathrm{F}\left(760^{\circ} \mathrm{C}\right)$.

18. The volume fraction of gamma prime in sheet Udimet 700 as a function of temperature.

19. Coarsening of garma prime in sheet Udimet 700 at elevated temperatures as a function of the cube root of time.

20. The cube of the rate constant, compensated by the change in concentration of the solute with temperature, as a function of reciprocal temperature.

2l. Transmission electron micrograph of a thin foil of Udimet 700 bar solution treated at $2150^{\circ} \mathrm{F}\left(1177^{\circ} \mathrm{C}\right)$ and aged 3 hours at $1500^{\circ} \mathrm{F}\left(816^{\circ} \mathrm{C}\right)$. 
22. Transmission electron micrographs of thin foils taken from the gauge sections of smooth specimens of sheet Udimet 700 solution treated, aged, and tensile tested at $1200^{\circ} \mathrm{F}\left(649^{\circ} \mathrm{C}\right)$.

23. Thin foil electron micrographs of smooth specimens of sheet Udimet 700 solution treated, aged 3 hours at $1500^{\circ} \mathrm{F}\left(816^{\circ} \mathrm{C}\right)$ and creep-rupture tested.

24. Transmission electron micrographs of thin foils of smooth specimens of sheet Udimet 700 solution treated, aged 24 hours at $1600^{\circ} \mathrm{F}\left(871^{\circ} \mathrm{C}\right)$ and creep-rupture tested.

25. Thin foil electron micrographs of smooth specimens of sheet Udimet 700 solution treated, aged 48 hours at $1700^{\circ} \mathrm{F}\left(927^{\circ} \mathrm{C}\right)$ and creep-rupture tested.

26. Transmission electron micrographs of thin foils of smooth specimens of sheet udimet 700 solution treated, aged 4 hours at $1975^{\circ} \mathrm{F}\left(1079^{\circ} \mathrm{C}\right)$ plus 24 hours at $1550^{\circ} \mathrm{F}\left(843^{\circ} \mathrm{C}\right)$ plus 16 hours at $1400^{\circ} \mathrm{F}\left(760^{\circ} \mathrm{C}\right)$ and creep-rupture tested.

27. Thin foil electron micrograph of a smooth specimen of Udimet 700 bar solution treated, aged 4 hours at $1975^{\circ} \mathrm{F}\left(1079^{\circ} \mathrm{C}\right.$ ) plus 24 hours at $1550^{\circ} \mathrm{F}\left(843^{\circ} \mathrm{C}\right)$ plus 16 hours at $1400^{\circ} \mathrm{F}$ $\left(760^{\circ} \mathrm{C}\right)$ and creep-rupture tested at $1200^{\circ} \mathrm{F}\left(649^{\circ} \mathrm{C}\right)$ at $110 \mathrm{ksi}$ $\left(758 \mathrm{MN} / \mathrm{m}^{2}\right)$.

28. The variation of the yield strength at $1200^{\circ} \mathrm{F}\left(649^{\circ} \mathrm{C}\right)$ of sheet Udimet 700 with the gamma prime particle size.

29. The dependence of the time-dependent notch sensitivity at $1200^{\circ} \mathrm{F}\left(649^{\circ} \mathrm{C}\right)$ of Udimet 700 sheet, bar and investment castings on the test stress and the gamma prime particle size.

30. The dependence of the time-dependent notch sensitivity at $1000^{\circ} \mathrm{F}\left(538^{\circ} \mathrm{C}\right)$ of Modified Waspaloy sheet on the test stress and gamma prime particle size.

31. The dependence of the time-dependent notch sensitivity at $1000^{\circ} \mathrm{F}\left(538^{\circ} \mathrm{C}\right)$ of Waspaloy sheet on the test stress and gamma prime particle size. 


\section{INTRODUCTION}

Studies of the notch sensitivity of heat-resistant materials have been carried out at The University of Michigan, Ann Arbor, Michigan, under sponsorship of the National Aeronautics and space Administration, Washington, D.C. Results have been reported for sheet nickel-base alloys: Waspaloy $[1,2]$, René 41 [3], Inconel 718 [4], TD-NiCr [5], and a low gamma prime volume fraction alloy "Modified Waspaloy" [5]. The present report covers results obtained for Udimet 700 .

The early studies indicated that time-dependent edge-notch sensitivity of sheet materials (Figure 1) occurs when: (a) edge-notched specimens are loaded below the approximate 0.2 percent smooth specimen offset yield strength and, (b) the dislocation mechanism is such that the creep deformation is localized and not homogeneous. The nature of the creep deformation in the alloys studied was dependent on the interaction of dislocations with precipitate particles. In the case of TD-NiCr, dislocations by-passed the incoherent Tho particles during creep which resulted in homogeneous deformation and no time-dependent notch sensitivity. The other alloys studied are strengthened by coherent precipitates. Particles smaller than a "critical" size were sheared by dislocations, whilst larger particles were by-passed by dislocations. These mechanisms resulted in localized and homogeneous deformation, respectively. The alloys were, therefore, susceptible to time-dependent notch sensitivity only when they contained coherent precipitates (smaller than the critical size)

* Numbers in brackets designate references at end of report. 
which were sheared by dislocations.

The critical particle size is dependent on the volume fraction of the coherent precipitate. The alloys previously evaluated had less than 25 percent preclpitate. Hence, to extend the scope of the concepts developed, Udimet 700 which has about 45 percent gamma prime, $\gamma^{1}, \mathrm{Ni}_{3}(\mathrm{Al}, \mathrm{TI})$, was studied. As the early investigations exclusively involved sheet materials, it was considered important to evaluate other product forms. Consequently, sheet, bar, and investment-cast Udimet 700 were studied. Smooth, edge-notched ("flat") and round-notched specimens of the experimental materials were tensile and creeprupture tested at temperatures from $1000^{\circ}$ to $1600^{\circ} \mathrm{F}\left(538^{\circ}-871^{\circ} \mathrm{C}\right)$. The microstructural features, particularly the dislocation-motion mechanisms, were evaluated. 
EXPERIMENTAL DETAIIS

Udimet 700 was recelved in the form of 0.1 -inch $(2.5 \mathrm{~mm})$ thick plate, 0.6-inch ( $15 \mathrm{~mm}$ ) diameter hot-rolled bar and investiment cast specimen blanks with $0.093 \times 0.75 \times 1.5-$ inch $(2.4 \times 19.1 \times 38 \mathrm{~mm})$ gauge sections. The following are the ladle compositions reported for the bar and cast materials (weight percent):

\begin{tabular}{|c|c|c|c|c|c|c|c|}
\hline & $\mathrm{C}$ & $\mathrm{Cr}$ & Co & Mo & $\mathrm{Ti}$ & $\mathrm{Al}$ & B \\
\hline Bar & 0.13 & 14.6 & 18.6 & 5.15 & 3.70 & 4.68 & 0.018 \\
\hline Cast & 0.08 & 14.5 & 14.9 & 4.20 & 3.38 & 4.28 & 0.016 \\
\hline & $2 x$ & $\mathrm{Fe}$ & $S$ & Mn & S1 & $\mathrm{Cu}$ & $\mathrm{Ni}$ \\
\hline Bar & 0.04 & 0.4 & 0.003 & $<0.1$ & $<0.1$ & $<0.1$ & balance \\
\hline Cast & 0.04 & 0.2 & - & $<0.1$ & $<0.1$ & $<0.1$ & balance \\
\hline
\end{tabular}

The plate material was reduced in an laboratory mill to a thickness of about 0.032 inch $(0.81 \mathrm{~mm})$ by cold rolling with periodic anneals at $1975^{\circ} \mathrm{F}$. $\left(1079^{\circ} \mathrm{C}\right)$. After pickling, this material was cold reduced $25-30$ percent in several passes to a final thickness of approximately 0.025 inch $(0.64 \mathrm{~mm})$. Longitudinal specimen blanks of the sheet, bar, and cast materials were individually solution treated in an argon atmosphere at $2150^{\circ} \mathrm{F}\left(1177^{\circ} \mathrm{C}\right)$. The exposures were $1 / 2$ hour for the sheet and 4 hours for the bar and castings. All of the materials were air cooled after solution treatment except for a limited number of blanks of the bar material which were water quenched. Subsequent treatments (aging) were:

(a) None - bar (water quenched). 
(b) 3 hours at $1500^{\circ} \mathrm{F}\left(816^{\circ} \mathrm{C}\right)$ - sheet, bar, and castings.

(c) 24 hours at $1600^{\circ} \mathrm{F}\left(871^{\circ} \mathrm{C}\right)$ - sheet and bar.

(d) 48 hours at $1700^{\circ} \mathrm{F}\left(927^{\circ} \mathrm{C}\right)$ - sheet.

(e) 4 hours at $1975^{\circ} \mathrm{F}\left(1079^{\circ} \mathrm{C}\right)$ plus 24 hours at $1550^{\circ} \mathrm{F}\left(843^{\circ} \mathrm{C}\right)$ plus 16 hours at $1400^{\circ} \mathrm{F}\left(760^{\circ} \mathrm{C}\right)$ - sheet, bar, and castings.

The treatments (b) through (d) were selected (from hardness tests of aged sheet material - Figure 2) to provide materials having gamma prime particles both smaller and larger than the "critical size" (corresponding to maximum hardness). Treatment (e) is the "multiple" aging treatment commonly used for Udimet 700. The aging treatments at $1975^{\circ} \mathrm{F}\left(1079^{\circ} \mathrm{C}\right)$ were carried out on individual blanks under argon. For the sheet materials, the remainder of the aging treatments were carried out in air. Batches of 10 or 12 of the specimen blanks were clamped in a fixture to prevent warping during these treatments. These fully heat-treated sheet materials were then machined into specimens. In the case of the bar and investment-cast materials, specimens were first machined and then the final aging treatments were carried out on the specimens sealed in evacuated quartz tubes.

The test program included both smooth and notched specimens. The sheet specimens (Figure 3) were the same as used in previous investigations [1-5]. The dimensions of the bar and cast specimens are shown in Figures 4 and 5 . Sheet and investment-cast specimens were edge-notched $\left(K_{t}{ }^{\prime} s\right.$ of $>20$ and 18 , respectively) while bar specimens were circumferential notched $\left(K_{t}=8\right)$.

Tensile and creep-rupture tests were conducted at temperatures from $1000^{\circ}$ to $1600^{\circ} \mathrm{F}\left(538^{\circ}-871^{\circ} \mathrm{F}\right)$. The test procedures have been reported [1].

For optical metallography, samples were etched electolytically in "G" 
etch [6]. The $\gamma^{\prime}$ volume fractions of solution-treated and aged samples were determined by electrolytic extraction using a solution of 1 percent ammonium sulphate plus 1 percent citric acid in water [7]. Techniques for the preparation of thin folls, for study by transmission electron microscopy, have been reported [2]. Lattice parameters of the $\gamma$ (matrix) and $\gamma^{\prime}$ phases for the sheet material heat treated $1 / 2$ hour at $2150^{\circ} \mathrm{F}\left(117 \mathrm{C}^{\circ}\right)$ plus 24 hours at $1600^{\circ} \mathrm{F}$. $\left(871^{\circ} \mathrm{C}\right)$ were determined by $\mathrm{x}$-ray diffraction using a $144.6 \mathrm{~mm}$ diameter Debye camera with nickel-filtered copper radiation. The extracted residue from the volume-fraction determination was used for the $x$-ray study of $\gamma^{\prime}$. The lattice parameter of the $\gamma$ phase was determined using a fine "wIre" of the alloy prepared by electrolytic thinning. 
MECHANICAL CHARACTERISTICS

The results of hardness tests are presented in Figure 2, while data from tensile and creep-rupture tests are included as Tables I through III. The principal features, particularly those related to the notch-sensitive behavior, are presented in the following sections.

\section{HARDNESS}

Room temperature hardness tests were conducted to characterize the responce of $\gamma^{\prime}$ in solution-treated sheet material to aging. The results (Figure 2) demonstrated that, with increasing severity of aging (increasing time and/or temperature), the hardness increases unt1l the $\gamma$ ' exceeds a "critical" size after which further growth results in a decrease in hardness. The level of maximum hardness differed for the various aging temperatures due to variations in the equilibrium volume fraction of $\gamma^{\prime}$ at the elevated temperatures (considered in subsequent section). The aging treatments: 3 hours at $1500^{\circ} \mathrm{F}\left(816^{\circ} \mathrm{C}\right)$, 24 hours at $1600^{\circ} \mathrm{F}\left(871^{\circ} \mathrm{C}\right)$, and 48 hours at $1700^{\circ} \mathrm{F}\left(927^{\circ} \mathrm{C}\right)$ were selected for the investigation as they resulted in $\gamma^{\prime}$ particles both smaller and larger than the critical size.

TENS ILE CHARACTERISTICS AT $1200^{\circ} \mathrm{F}\left(649^{\circ} \mathrm{C}\right)$

The tensile properties varled according to the aging treatment (Tables I, II, and III). The tensile characteristics of the sheet material, as a function of $\gamma^{\prime}$ size, are shown in Figure 6 (the results of size measurements are presented in a subsequent section). Note especially that, as was the case for 
hardness, the yield strength increased and subsequently decreased with increasing particle size. The theoretical and practical significance of this will be discussed later.

There were differences in tensile properties measured for the various product forms (Tables I; II, III). Factors that could be expected to contribute to these differences are: specimen shape, grain size, $\gamma^{\prime}$ particle size, and volume fraction. The high tensile strengths of the bar material can be attributed, at least in part, to the specimen shape that differed markedly from that used for the sheet and investment-cast materials. Circumferential notches in the round specimens introduced triaxial stresses, whereas edgenotches in the "flat" (sheet and investment cast) specimens introduced a blaxial stress concentrations. In contrast to the biaxial case, a triaxial stress state can signiflcantly reduce the effective stress and, thereby, cause higher tensile (and creep) strengths. Although this effect was most evident from the notched specimen results, it also influenced smooth specimen properties as triaxial stresses were introduced during necking of round specimens.

All of the tensile-tested specimens failed transgranularly ("low" temperature-type failures). As a consequence, the tensile strengths could be expected to be decreased by increasing the grain size (average grain diameters: sheet $-0.15 \mathrm{~mm}$, bar $-0.11 \mathrm{~mm}$, investment castings -0.06 to $0.32 \mathrm{~mm}$ ).

Tensile strengths can be increased by increasing the $\gamma^{\prime}$ volume fraction. Minor differences in the volume fraction that occurred for the various product forms must have had some Influence on the relative properties of the various products (sheet, bar, and castings were about 44, 48, and 50 percent $\gamma^{\prime}$, respectively). 
For a given aging treatment, the $y^{\prime}$ particle size varled with product form and thereby influenced the tensile properties. This occurred because $\gamma^{\prime}$ precipitated and coarsened during cooling from the solution treatment temperature. The greater the section size the larger the $\gamma^{\prime}$ that resulted on air cooling and after subsequent aging. Although these differences affected the tensile properties, their influence on the creep-rupture strength, particularly those for notched specimens, was greater.

\section{CREEP-RUPTURE，STRENGTHS}

Extensive test results obtained for the sheet materials (Table I) are presented first, followed by an evaluation of the more limited test results for the bar and cast materials (Tables II and III).

The smooth specimen rupture strengths (Figure 7) of the various heattreated sheet materials differed at the low parameter values (short times and) or low temperatures) but became more similar at higher parameter values. This was due, at least in part, to growth of $\gamma^{\prime}$ during the high-temperature test exposures. For the material aged 3 hours at $1500^{\circ} \mathrm{F}\left(8.6^{\circ} \mathrm{C}\right)$, many of the smooth specimens failed elther at the pin holes or the shoulders (Table I). This reflects the high sensitivity of the rupture strengths of this material to even mild notches (this material was highly susceptible to time-dependent notch sensitivity).

All of the sheet materials (Figures 8 through 11) exhibited time-dependent notch sensitivity at the lower test temperatures, $1000^{\circ}$ to $1200^{\circ} \mathrm{F}\left(538^{\circ}-649^{\circ} \mathrm{C}\right)$ (about 0.4 to 0.5 of the melting point, $T_{m}$, of the alloy). In other words, the notched-to-smooth strength ratios $(\mathrm{N} / \mathrm{S})$ in rupture tests decreased with time to 
values considerably below those determined by tensile tests (Table I). In contrast to the behavior at low temperatures, for the rupture tests at $1600^{\circ} \mathrm{F}$ $\left(871^{\circ} \mathrm{C}\right)$ (about $0.66 \mathrm{~T}_{\mathrm{m}}$ ) and, in some cases at $1400^{\circ} \mathrm{F}\left(760^{\circ} \mathrm{C}\right)$, the $\mathrm{N} / \mathrm{S}$ rupture strength ratios were high, 1.e., time-dependent notch sensitivity did not occur. This notch-sensitive behavior has the same general characteristics as reported [1-5] for other $y^{\prime}$ strengthened superalloys.

In the earlier studies it was shown that the drastic increase in the steepness In the notched specimen rupture curve, wh1ch causes the increase in notch sensitivity, occurs at the approximate 0.2 percent smooth specimen offset yield strength $\left(\sigma_{y}\right)$. The results of the present investigation are not inconsistent with this observation. The decrease in notch sensitivity that occurred with increasing time was due to an upward break in the notched specimen rupture curve. The stress at which the upward break occurred $\left(\sigma_{n}\right)$ was a function of the heat treatment and the test temperature. These factors will be discussed further in a subsequent section.

The rupture strengths of smooth specimens of the bar material (Figure 12) were independent of the various aging treatments used 3 hours at $1500^{\circ} \mathrm{F}$ $\left(816^{\circ} \mathrm{C}\right), 24$ hours at $1600^{\circ} \mathrm{F}\left(871^{\circ} \mathrm{C}\right)$, and the "multiple" treatment . The strengths were higher than obtained for the sheet materlals. Time-dependent notch sensitivity occurred for the bar materials aged at $1500^{\circ} \mathrm{F}\left(816^{\circ} \mathrm{C}\right)$ and $1600^{\circ} \mathrm{F}\left(871^{\circ} \mathrm{C}\right)$, but was less severe than evident for simllarly heat treated sheet material (Figures 13, 14, and 15). Time-dependent notch sensitivity. was not observed from the tests carried out on the "multiple" aged bar material (Figure 15). Limited notched specimen tests for solution-treated and water- 
quenched bar indicated that it suffered from a very severe time-dependent notch sensitivity (Figure 13).

The edge-notched and smooth specimen rupture strength characteristics of the investment-cast materials (Figures 16 and 17) were similar in nature to those described for similarly heat treated sheet material. Some minor differences in strength levels and severity of notch sensitivity were evident. 
MICROSTRUCTURAL FEATURES

As-heat-treated materials were studied in order to characterize the microstructural features, particularly the $\gamma^{\prime}$ phase. Subsequently, tensile and creep-rupture tested specimens were examined by transmission electron microscopy in order to establish the dislocation mechanisms operative and, also changes in the $\gamma^{\prime}$ phase that resulted from the elevated temperature test exposures. Samples for study were taken. somewhat removed from the fractures of smooth specimens and, hence, represented the materials in the early stages of cracking.

Extensive structural evaluation was conducted for the sheet materials. Sufficient study was then made of the bar and cast materials to establish their characteristics relative to those for the sheet materials.

VOLUME FRACTION OF GAMMA PRTME $\left(V_{f^{\prime}}\right)$

The volume fractions of $\gamma^{\prime}$ were determined by electrolytic extraction [7] of solution-treated (1/2 hour at $2150^{\circ} \mathrm{F}\left(1177^{\circ} \mathrm{C}\right)$ and air cooled) and solutiontreated and aged sheet materials. The results are presented in Figure 18 . Also included are results from a study reported by Van Der Molen et al. [8], in which volume fractions of $\gamma^{\prime}$, in Udimet 700 were determined from dropquenched specimens. For the higher temperature exposures, the air-cooled sheet specimens of the present study contained much higher $\gamma^{+}$volume fractions than the reported values [8]. This occurred because considerable $\gamma^{\prime}$ precipitated (and coarsened) during air cooling which, presumably, did not occur to 
any great extent for the drop-quenched materials. The dashed curve on Figure 18 represents an estimate of the equilibrium volume fraction of $\gamma^{\prime}$ as a function of temperature for the sheet material. At the lower temperatures the material was about 44 percent $y^{\prime}$. Extractions indicated that at low temperatures the bar and cast materials were about 48 and 50 percent $\gamma^{\prime}$; respectively.

GAMMA PRIME PARTICLE SIZE

Average $\gamma^{\prime}$ particle sizes were measured for as-heat-treated materials and rupture-tested smooth specimens. The determinations were made by the measurement of approximately 500 particles in transmission electron micrographs of thin foils.*

The particle size data for the sheet materials were considered in terms of growth according to (time $)^{1 / 3}$ in the same manner as described by van Der Molen et al. [8]. This reported study showed that the coarsening of $\gamma^{\prime}$ in Udimet 700 at temperatures from $1800^{\circ}$ to $2000^{\circ} \mathrm{F}\left(982^{\circ}-1039^{\circ} \mathrm{C}\right)$ followed the relationship:

$$
\left[\bar{r}^{-3}-\bar{r}_{0}^{3}\right]^{1 / 3}=\mathrm{kt}^{1 / 3}
$$

where: $\vec{r}$ is the average particle radius at time $t$,

$\bar{r}_{0}$ is the average radius at $t=0$, and

$\mathrm{k}$ is a temperature-dependent rate constant.

\footnotetext{
*This technique can provide accurate results as long as the particles are small relative to the foil thickness (order of $2000 \AA$ ). Calculations have shown that when the average particle size equals the thickness of a perfectly thinned foil, errors in the average size of about 4 percent can be expected. Increasingly larger errors occur as the particle size increases relative to the thickness.
} 
Data obtained in the present investigation for solution-treated and aged sheet Udimet 700 are presented in Figure 19. The curves were drawn so that values of $\left[\bar{r}^{3}-\bar{r}_{0}^{3}\right]^{1 / 3}$ varied linearly with the cube root of time in accordance with the above equation. At zero time the average particle radius $\left(r_{0}\right)$ was about

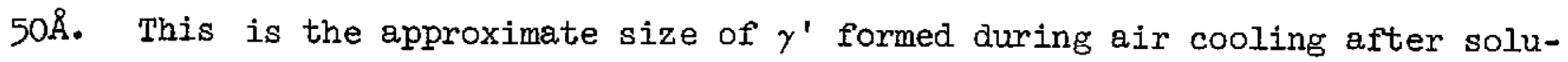
tion treatment at $2150^{\circ} \mathrm{F}\left(1177^{\circ} \mathrm{C}\right)$. The slopes of the lines in Figure 19 are the temperature-dependent rate constants $k$ which are given by [8]:

$$
\ln \left[\mathrm{k}^{3}(\mathrm{~T} / \mathrm{Ce})\right]=\mathrm{A}(-\mathrm{Q} / \mathrm{RT})
$$

where: $Q$ is an activation energy for coarsening (dependent on the diffusion of aluminum and titanium in the matrix),

$\mathrm{Ce}$ is the concentration of solute in equilibrium with a particle of infinite radius,

$\mathrm{T}$ is the absolute temperature,

$R$ is the gas constant, and

A is a constant.

Thus, the activation energy for coarsening can be determined from a plot of $\log \left[\mathrm{k}^{3}(\mathrm{~T} / \mathrm{Ce})\right]$ versus $1 / \mathrm{T}$. This is shown in Figure 20 for data obtained in the current investigation but using reported values for $\mathrm{Ce}$ [8]. At temperatures above about $1700^{\circ} \mathrm{F}\left(927^{\circ} \mathrm{C}\right)$ the data agree well with the results of van Der Molen et al. [8]. The activation energy for coarsening is about $60 \mathrm{kcal} / \mathrm{mole}$ which approximates the activation energies for diffusion of aluminum and titanium in nickel (64.4 and $61.4 \mathrm{kcal} / \mathrm{mole}$, respectively). However, at the lower temperatures (not studied in Reference 8) the activation energy for growth was considerably higher (about $130 \mathrm{kcal} / \mathrm{mole}$ ). It is interesting to note that 
these characteristics are similar to the results of measurements of the apparent activation energy for creep obtained for many nickel-base alloys.

Limited data for coarsening under stress for the sheet material heat treated $1 / 2$ hour at $2150^{\circ} \mathrm{F}\left(117^{\circ} \mathrm{C}\right)$ plus 3 hours at $1500^{\circ} \mathrm{F}\left(816^{\circ} \mathrm{C}\right)$ and creeprupture tested (Figure 20) indicated a higher growth rate than for the corresponding unstressed exposures. In fact, these results indicate an activation energy for growth under stress of about $60 \mathrm{kcal} / \mathrm{mole}$ at all temperatures considered. Further data would be required to substantiate this observation. As shown later, under these conditions, the $\gamma^{\prime}$ particles were sheared by $\langle 110\rangle$ type dislocations-this could have caused the faster growth [9].

In two cases, bimodal distributions of $\gamma^{\prime}$ particle sizes were observed in sheet materials. The "multiple" aging treatment resulted in a $\gamma$ ' volume fraction of approximately 0.20 with an average size of about $3000 \AA$ [due to the 4hour age of $\left.1975^{\circ} \mathrm{F}\left(1079^{\circ} \mathrm{C}\right)\right]$ while, the remainder of the $\gamma^{\prime}$ (volume fraction about 0.24 ) had an average size of approximately $430 \AA$ [due to aging at $1550^{\circ} \mathrm{F}$ $\left(843^{\circ} \mathrm{C}\right)$ and $\left.1400^{\circ} \mathrm{F}\left(760^{\circ} \mathrm{C}\right)\right]$. For this heat-treated material, the bimodal distribution of sizes persisted in all of the specimens examined which were creeprupture tested at temperatures up to $1400^{\circ} \mathrm{F}\left(760^{\circ} \mathrm{C}\right)$. In the specimen tested at $1600^{\circ} \mathrm{F}\left(871^{\circ} \mathrm{C}\right)$ at $20 \mathrm{ksi}\left(138 \mathrm{MN} / \mathrm{m}^{2}\right)$ there was a unimodal $\gamma^{\circ}$ distribution with an average size of about $3730 \AA$. This occurred because the test temperature was above the aging treatment temperatures of $1550^{\circ}$ and $1400^{\circ} \mathrm{C}\left(843^{\circ}\right.$ and $\left.760^{\circ} \mathrm{C}\right)$

In the sheet materials aged at the highest temperatures, especially the material aged at $1700^{\circ} \mathrm{F}\left(927^{\circ} \mathrm{C}\right)$, "ultrafine" $\gamma^{\prime}$ precipitated during air cooling 
from the aging temperature and then developed during high-temperature testing. The volume fraction of this $y^{\prime}$ was less than about 0.05 .

Limited studies were carried out to characterize the $\gamma^{\prime}$ size and distribution for the heat-treated bar and investment cast materials. As noted previously, $y^{\prime}$ precipitated and coarsened during cooling from the solution treatment temperature. The greater the section size the larger the $\gamma^{\prime}$ that developed. This had a major influence on the $\gamma^{\prime}$ size distribution for the heattreated bar materials and, to a lesser extent, for the investment-cast materials (Table IV). Relatively large particles (about 1170-1570 in diameter) formed on air cooling the bar material from $2150^{\circ} \mathrm{F}\left(1177^{\circ} \mathrm{C}\right)$, while, smaller particles (approximately 520-760 ) occurred in the air-cooled investment-cast materials. Even water-quenched bar material contained $\gamma^{\prime}$ particles about 100$850 \AA$ in diameter. The relatively large $\gamma^{\prime}$ size for these materials should be compared to the $100 \AA$ diameter particles in the solution-treated and air-cooled sheet materials (Table IV).

There was a considerable range of $\gamma^{\prime}$ particle sizes in the larger section sized materials. The particles were smaller near the surface than at the center where the cooling rate was considerably slower. The $\gamma^{\prime}$ size distribution observed for the bar material solution treated and aged 3 hours at $1500^{\circ} \mathrm{F}$ $\left(816^{\circ} \mathrm{C}\right)$ is shown in Figure 2l. Large particles developed during air cooling from the solution treatment and then coarsened somewhat during aging to a final average size of about 1300-1900^. Also during aging, "fine" $\gamma$ ' grew to about $130 \AA$ in diameter. Bimodal $\gamma^{\prime}$ size distributions of this type occurred in all the heat-treated bar materials (Table IV). 
For the investment-cast materials, relatively small $\gamma^{\prime}$ resulted from air cooling after solution treatment and, an (essentially) unimodal distribution of $\gamma^{\prime}$ particle sizes was observed for the material aged at $1500^{\circ} \mathrm{F}$ ( $816^{\circ} \mathrm{C}$ ). The multiple aged cast material contained a bimodal $\gamma^{\prime}$ size distribution (Table IV).

\section{DISLOCATION STRUCTURES}

The dislocation structures in tensile and creep-rupture tested specimens varied with product form, heat treatment, test temperature and stress. In alloys of the type studied, the dislocation-motion mechanism is governed by the nature of the interaction of dislocations with the $\gamma^{\prime}$ particles. The most important variables are the $\gamma^{\prime}$ volume fraction (essentially constant for a given alloy), the $\gamma^{\prime}$ particle size (and distribution), and the test stress and temperature.

Sheet Smooth Specimens Tensile Tested at $1200^{\circ} \mathrm{F}\left(649^{\circ} \mathrm{C}\right)$

For the sheet material aged 3 hours at $1500^{\circ} \mathrm{F}\left(816^{\circ} \mathrm{C}\right)$, tensile deformation occurred by the motion of $a / 2<110>$ type superlattice pairs which sheared the small $\gamma^{\prime}$ particles (about $230 \AA$ in diameter) [10-12]. In several instances the dislocations were present as extended stacking fault ribbons. When this mechanism occurred the deformation was localized in slip bands (Figure 22a). With increasing particle size the deformation became more homogeneous. For the material aged 48 hours at $1700^{\circ} \mathrm{F}\left(927^{\circ} \mathrm{C}\right)$ the $\gamma^{\prime}$ particles were approximately $1900 \AA$ in diameter. Dislocations were observed bowing between particles (Figure $22 b)$. In some regions, concentric dislocations were observed around $\gamma^{\prime}$ particles which indicated that these were pinched off by the orowan by-pass 
mechanism [12]. This mechanism results in homogeneous deformation [2]. In many cases (Figure 22b) the dislocations bowed in pairs. It is believed that these superdislocations formed in order to lower the energy necessary for the dislocations to shear ultrafine $\gamma^{\prime}$ particles [formed during cooling the material after aging at $\left.1700^{\circ} \mathrm{F}\left(927^{\circ} \mathrm{C}\right)\right]$. In some areas of the specimen the deformation was more localized and was associated with <110> type shear (Figure $22 c)$

The dislocation structure for the material aged 24 hours at $1600^{\circ} \mathrm{F}\left(871^{\circ} \mathrm{C}\right)$, which had an average $\gamma^{\prime}$ size of about $650 \AA$, was intermediate in nature. For the material with the "multiple" aging treatment, <110> type superdislocations sheared the large $\gamma^{\prime}$ (about $3000 \AA$ in diameter) and also the small particles (approximately $430 \AA$ in diameter). The deformation was localized (Figure $22 d$ ).

Creep-Rupture Tested Sheet Specimens

For the sheet material aged 3 hours at $1500^{\circ} \mathrm{F}\left(816^{\circ} \mathrm{C}\right)$, creep at $1000^{\circ}$ and $1200^{\circ} \mathrm{F}\left(538^{\circ}, 649^{\circ} \mathrm{C}\right)$ occurred by $<110>$ type shear (Figure 23a). Many extended stacking fault ribbons were observed and the deformation was highly localized. Similar dislocation structures were observed for the specimen tested at $1400^{\circ} \mathrm{F}$ $\left(760^{\circ} \mathrm{C}\right)$ at $50 \mathrm{ksi}\left(345 \mathrm{MN} / \mathrm{m}^{2}\right)$ which muptured in 10 hours. However, in the specimen tested at $35 \mathrm{ksi}\left(24 \mathrm{MN} / \mathrm{m}^{2}\right)$ at $1400^{\circ} \mathrm{F}\left(760^{\circ} \mathrm{C}\right)$ a different dislocation structure was observed (Figure 23b). In some areas $<112>$ type shear had occurred [13-16]. This mechanism, which has been observed for other high $\gamma^{\prime}$ volume fraction alloys $[14,16]$, involves the shearing of $\gamma^{\prime}$ by loosely coupled intrinsic/extrinsic fault pairs. This type of deformation results in less 
localized deformation than $\langle 110\rangle$ type shear. As will be shown subsequently, during creep $<112>$ type deformation became more prevalent with increasing particle size. It has been reported [14]. that, because $<112>$ type shear is most likely controlled by diffusion, it only occurs at low strain rates and/or relatively high temperatures. Thus for the specimen tested at $35 \mathrm{ksi}$ ( 241 $\left.\mathrm{MN} / \mathrm{m}^{2}\right)$ at $1400^{\circ} \mathrm{F}\left(760^{\circ} \mathrm{C}\right)$, the "high" temperature, low strain rate, and the presence of large $\gamma^{\prime}$ particles (the particles grew to about $2100 \AA$ during the test exposure) probably acted to promote $\langle 112\rangle$ type shear.

As the test temperature (and time) is increased diffusional-controlled creep and recovery processes become more important. These processes presumably influenced the dislocation structures produced by long-time testing at $1400^{\circ} \mathrm{F}$ $\left(760^{\circ} \mathrm{C}\right)$. This was certainly the case for the tests at $1600^{\circ} \mathrm{F}\left(871^{\circ} \mathrm{C}\right)$. In the specimen tested at $30 \mathrm{ksi}\left(207 \mathrm{MN} / \mathrm{m}^{2}\right.$ ) the deformation was homogeneous (Figure 23c). Dislocation networks were observed at the $\gamma / \gamma^{\prime}$ interfaces with few dislocations observed inside the $\gamma^{\prime}$ particles. (Note that for the purpose of this report, the deformation is characterized as "homogeneous" when the dislocations were distributed throughout the matrix but not necessarily within the $\gamma^{\prime}$ phase.)

Reported work [16], indicates that the predominant creep mechanism at $1600^{\circ} \mathrm{F}\left(871^{\circ} \mathrm{C}\right)$ involved shearing of $\gamma^{\prime}$ by constricted a $/ 2<110>$ dislocation pairs. (Consistent with the reported study, the individual $\langle 110\rangle$ dislocations were only clearly visible for the heat-treated materials which contained larger $\gamma^{\prime}$ particles.) The occurrence of $\langle 110\rangle$ type deformation at the highest test temperature can be attributed to a drastic decrease in the $\gamma^{\prime}$ antiphase 
boundary energy when the temperature was increased above about $1400^{\circ} \mathrm{F}\left(760^{\circ} \mathrm{C}\right)$ [16]. Most important, however, is the observation that, at the highest test temperatures, the deformation was homogeneous.

A parallel series of observations was made for the material aged 24 hours at $1600^{\circ} \mathrm{F}\left(871^{\circ} \mathrm{C}\right.$ ) (Figure 24). The most significant difference was that, due to the larger $\gamma^{\prime}$ particles, even at the "lower" test temperatures of $1000^{\circ}$ and $1200^{\circ} \mathrm{F}\left(538^{\circ}, 649^{\circ} \mathrm{C}\right),<112>$ type shear was quite prevalent. For the material aged 48 hours at $1700^{\circ} \mathrm{F}\left(927^{\circ} \mathrm{C}\right)$ the $y^{\prime}$ particles were even larger and $<112>$ type shear was the predominant creep mechanism at the lower test temperatures, even so, some $\langle 110\rangle$ type shear occurred (Figure 25). Corresponding to the increase in $\langle 112\rangle$ type relative to $\langle 110\rangle$ type shear, the deformation became less localized with increasing particle size.

The multiple-aged material deformed at the lower temperatures by both $<110\rangle$ and $\langle 112\rangle$ type shear (Figure 26). The deformation was localized. With increasing time and temperature, the deformation became more homogeneous. In specimens tested at $1600^{\circ} \mathrm{F}\left(871^{\circ} \mathrm{C}\right)$ no "fine" $\gamma$ ' was present, and the dislocations were homogeneously distributed (Figure 26e,f). Dislocation pairs were clearly evident for the specimen tested at $30 \mathrm{ksi}\left(207 \mathrm{MN} / \mathrm{m}^{2}\right)$ while for the specimen tested at $20 \mathrm{ksi}\left(138 \mathrm{MN} / \mathrm{m}^{2}\right)$ well developed dislocation networks occurred at the phase boundaries. The structures observed occur when the particles are sheared by $\langle 110\rangle$ dislocations and are modified by climb and recovery processes [16]. Under these "high" temperature test conditions the deformation was homogeneous. 
Creep-Rupture Tested Bar and Investment Cast Specimens

The extensive microstructural study of the sheet materials was used to define the manner which the dislocation mechanism varied with the $\gamma^{\prime}$ size and distribution and the test temperature and stress. As these relationships have general applicability, only a limited microstructural study was carried out for tested specimens of the bar and investment cast materials.

Of all of the materials tested, only the bar in the "multiple" aged condition did not exhibit time-dependent notch sensitivity. It was, therefore, of interest to determine the dislocation structure present in this material creeprupture tested at a "low" temperature. Examination of the specimen tested at $1200^{\circ} \mathrm{F}\left(649^{\circ} \mathrm{C}\right)$ at $110 \mathrm{ksi}\left(758 \mathrm{MN} / \mathrm{m}^{2}\right)$ showed that the dislocations were homogeneously distributed (Figure 27). It can be concluded that the homogeneous distribution of dislocations arose due to the presence of the large $\gamma^{\prime}$ particles in tnis material (the size distribution was bimodal with average $\gamma^{\prime}$ sizes of about $4100-4600 \AA$ and $750 \AA)$. 


\section{DISCUSSION}

THEORETICAL CONS IDERATIONS

The strength of dispersion strengthened materials can be calculated from theoretical concepts. Gleiter and Hornbogen [2] reported that the increase in critical resolved shear stress, CRSS, arising from particles possessing longrange order that are sheared by dislocations, $\Delta \tau_{s h}$, can be determined from the following equation:

$$
\Delta \tau_{\text {sh }}=0.28 \gamma_{A}^{3 / 2} \mathrm{~V}_{\mathrm{f}^{1 / 3}}(\mathrm{D} / 2)^{1 / 2} \mu^{-1 / 2} \mathrm{~b}^{-2},
$$

where: $\quad \gamma_{A}=$ antiphase boundary energy $\left(161 \mathrm{ergs} / \mathrm{cm}^{2}\right) *$

$$
\begin{aligned}
& \mathrm{v}_{\mathrm{f}}=\text { precipitate volume fraction }(0.44) \\
& \mathrm{D}=\text { mean particle diameter } \\
& \mu=\text { matrix shear modulus }\left(1.0 .10^{7} \mathrm{psi}-6.9 \times 10^{4} \mathrm{MN} / \mathrm{m}^{2}\right) \\
& \mathrm{b}=\text { Burgers vector }(\mathrm{a} / 2\langle 110\rangle=2.53 \hat{\mathrm{A}})
\end{aligned}
$$

The corresponding increased strength of a polycrystalline material, $\Delta \sigma_{\text {sh }}$, can be taken to be $3.06 \Delta \tau_{\text {sh }}$, where 3.06 is the Taylor factor [17]. The antiphase boundary energy of $161 \mathrm{ergs} / \mathrm{cm}^{2}$ for the $\{11.1\}$ plane of the $\gamma^{\prime}$ in Udimet 700 was calculated from the relationship [18]:

$$
\gamma_{A}=\frac{2.42 k \mathrm{TC} \mathrm{S}^{2}}{a^{2} \sqrt{3}}
$$

where: $\quad k=$ Boltzmann's constant

$$
a=\text { lattice parameter of } y^{\prime}(3.58 \AA)
$$

*Values in brackets are for sheet udimet 700 at $1200^{\circ} \mathrm{F}\left(649^{\circ} \mathrm{C}\right)$. 


$$
\begin{aligned}
\mathrm{T}_{\mathrm{c}}= & \text { critical ordering temperature (about } 2640^{\circ} \mathrm{F}-1449^{\circ} \mathrm{C} \text { ) } \\
\mathrm{S}= & \text { long-range order parmeter (calculated from the } \gamma^{\prime} \text { composition } \\
& {[19] \text { to be } 0.78) . }
\end{aligned}
$$

The coherency strains between the $\gamma^{\prime}$ and the $\gamma$ matrix can also have a strengthening role (for both shearing and by-passing). Gerold and Haberkorn [20] proposed the following relationship for the increase in CRSS due to coherency strain:

$$
\Delta \tau_{c}=3 \mu \varepsilon^{32}\left(\frac{V_{f} D}{2 b}\right)^{1 / 2}
$$

where: $\varepsilon$ is the constrained misfit $(=2 / 3$ the unconstrained misfit). The lattice parameters of extracted $\gamma^{\prime}$ (unconstrained) and $\gamma$ (constrained) for heat-treated Udimet 700 sheet materlal were determined by x-ray diffraction. Within the accuracy of the measurements, no significant difference was evident between the lattice parameters of these phases (a's of $3.584 \AA$ ). It can be concluded that little or no misfit occurred and, thus, the contribution of coherency strain to strengthening was negligible for this particular alloy.

The increase in yield strength due to the presence of $\gamma^{\prime}$ was, therefore, taken to be $\Delta \sigma_{s h}$. Calculated values for $\Delta \sigma_{s h}$ at $1200^{\circ} \mathrm{F}\left(649^{\circ} \mathrm{C}\right)$, as a function of particle size, are shown in Figure 28. It should be noted at this point that recently Copley and Kear [2l] introduced a dynamic theory for calculating the CRSS for shearing. This formulation has not been used in the present investigation since appropriate values were not avallable for all of the necessary terms. It has been noted, however, that this dynamic method results in somewhat lower CRSS (by about 10 percent) than determined by the static method [21]. 
The yleld strength of dispersion strengthened alloys, $\sigma_{y}$, can be determined by adding the yield strength of the matrix, $\Delta \sigma_{m}$, to the increase in strength due to the presence of the particles, $\Delta \sigma_{p}$. Comparison of values at $1200^{\circ} \mathrm{F}\left(649^{\circ} \mathrm{C}\right)$ for $\sigma_{\mathrm{y}}$ (measured) and $\Delta \sigma_{\mathrm{p}}\left(\right.$ calculated $\left.\Delta \sigma_{s h}\right)$ for the sheet material aged 3 hours at $1500^{\circ} \mathrm{F}\left(816^{\circ} \mathrm{C}\right.$ ) (Figure 28), indicates $\Delta \sigma_{\mathrm{m}}$ to be about 90 $\mathrm{ksi}\left(620 \mathrm{MN} / \mathrm{m}^{2}\right)$. A value for $\Delta \sigma_{\mathrm{m}}$ was not determined experimentally. Consideration of data available in the literature for solution-strengthened nickelbase alloys Indicated that a reasonable estimate for the yleld strength of the matrix at $1200^{\circ} \mathrm{F}\left(649^{\circ} \mathrm{C}\right)$ would be about $80 \mathrm{ksi}\left(552 \mathrm{MN} / \mathrm{m}^{2}\right)$. Thus, when the $\gamma^{\prime}$ particles were sheared by $\langle 100\rangle$ type dislocations, the yield strength was predicted very well using the theoretical concepts (Equation (3)).

By-passing of particles by the bowing of dislocations and pinching off dislocation loops, occurs at stresses greater than the "Orowan" stress. The following formulation for the Orowan stress, $\Delta \tau_{0}$ (the increase in CRSS due to the presence of non-deforming part1cles), was reported by Ashby [22]:

$$
\Delta \tau_{0}=B \frac{A \mu b}{2 \pi(\lambda-d)} \ln \left(\frac{d}{4 b}\right)
$$

where: $d=$ mean planar particle size $(0.82 \mathrm{D})$

$\lambda=$ mean planar center-to-center particle separation

$$
=\mathrm{d}\left(1 / \mathrm{v}_{\mathrm{f}}\right)^{1 / 2}[23]
$$

$B=$ statistical factor (about 0.85 ) related to the occurrence of a distribution of interparticle spacings.

$A=$ constant equal to 1 for an edge dislocation and $(1-v)^{-1}$ for a screw dislocation, where $v$ is Poisson's rat1o. Reportediy [23], $A$ can be taken to be the geometric mean. (Assuming a value of 0.3 for $v$, A is 1.29.) 
Values were calculated f'or $\Delta \sigma_{0}$ for the sheet material at $1200^{\circ} \mathrm{F}\left(649^{\circ} \mathrm{C}\right)$ as a function of particle size. However, it was clearly evident that these calculated stresses were excessive. It is possible that this occurred because the formula was intended for a relatively small volume fraction of nondeforming precipitate particles (Udimet 700 contained about 44 percent $\gamma^{\prime}$ ). The sheet material aged 48 hours at $1700^{\circ} \mathrm{F}\left(927^{\circ} \mathrm{C}\right)$ contained $\gamma^{\prime}$ particles with an average size of approximately 1920A. The yield strength of $104.5 \mathrm{ksi}(720$ $\mathrm{MN} / \mathrm{m}^{2}$ ) was assoclated with dislocations by-passing the $\gamma^{\prime}$, articles. Assuming a value of about $80 \mathrm{ksi}\left(552 \mathrm{MN} / \mathrm{m}^{2}\right)$ for $\Delta \sigma_{\mathrm{m}}$, the Increase in strength due to the presence of particles by-passed by Orowan looping, $\Delta \sigma$, would have to be approximately $25 \mathrm{ksi}\left(172 \mathrm{MN} / \mathrm{m}^{2}\right)$. This value is about 30 percent of the calculated value. The curves of Figure 28 are based on this "corrected" value for the Orowan stress. Although behavioral trends are evident from Figure 28 , modification of the theoretical work (Equation (6)) would be required before the yield strength can be calculated from basic material characteristics.

CORRELATTON OF THE TIME-DEPENDENT NOTCH SENS ITTVITY WITH THE DISLOCATION MECHANISM

In the previous studies of Waspaloy [2], Inconel 718 [4], and Modified Waspaloy [5], a correlation was established between the mode of deformation and the notch-sensitive behavior of the sheet alloys. When coherent precip1tate particles, smaller than a critical size, were sheared by $\langle 110\rangle$ type dislocations the deformation was localized. Under these circumstances, timedependent notch sensitivity was observed from edge-notched specimen tests conducted below the approximate 0.2 percent offset yield strength $\left(\sigma_{\mathrm{y}}\right)$. When 
larger particles were by-passed by dislocations, the deformatfon was homogeneous and time-dependent notch sensitivity was not evident.

In the present study of sheet Udimet 700 , room temperature hardness and yleld strengths at $1200^{\circ} \mathrm{F}\left(649^{\circ} \mathrm{C}\right)$ increased with increasing $\gamma^{\prime}$ particle size until they exceeded a "critical" size (maximum hardness or $\sigma_{y}$ ), after which further increase in size resulted in a decrease in hardness or yield strength (Figures 2 and 6). Correspondingly, the dislocation motion mechanism apparently changed from <llo> type shear to by-passing by orowan looping. In the low temperature creep-rupture tests of all the heat-treated sheet materlals evaluated, dislocations sheared the $\gamma^{\prime}$ and the deformation was localized. Thus, in contrast to results previously reported for lower precipitate volume fraction alloys, even when the particles were larger than the "critical" size they were sheared by dislocations. This situation arose because <ll2> type shear (a diffusion-controlled mechanism) occurred during creep but not in the "time independent" hardness and tensile tests. Consistent with the fact that $\langle 110\rangle$ or $\langle 112\rangle$ type shear occurred for all the heat-treated sheet materials creeprupture tested at the lower test temperatures, they all exhibited timedependent notch sensitivity.

In previous investigations [1-5], it was shown that the notch-sensitive behavior of sheet materfals depends on the notched specimen test stress relative to the approximate 0.2 percent offset smooth specimen yleld strength. When notched specimens are tested above the yield strength, yielding on loading reduces the stresses across the specimen at the base of the notch to the approximate nominal stress and, as a consequence, time-dependent notch sensitivty 
does not occur. On the other hand, when notched specimens are loaded to stresses below the yield strength, the stress concentrations can only be fully relaxed by creep (from the approximate yield strength to the nominal stress). As a result, time-dependent notch-sensitivity occurs when the creep deformation, necessary to relax the stress concentrations, causes excessive creep damage that results in premature crack initiation and failure. The results for sheet Udimet 700 were not inconsistent with these observations. Sufficient tests were not, however, conducted to definltely establish the notched specimen creepruture strengths above the yield strengths.

At the lower test temperatures, the notched sheet specimen stress-rupture time curves exhibited a decrease in steepness which caused the severity of the notch sensitivity to decrease with time (Figures 8 through 11 ). The stress at which the upward break occurred, $\sigma_{n}$, increased with increasing $\gamma^{\prime}$ particle size (Figure 29). Presumably, the upward break results when the stress is reduced low enough so that little or no creep can occur. This explanation is also consistent with the fact that test data indicated the $\sigma_{n}$ tended to increase with decreasing temperature. For the sheet material aged 3 hours at $1500^{\circ} \mathrm{F}\left(816^{\circ} \mathrm{C}\right)$, creep at $1200^{\circ} \mathrm{F}\left(649^{\circ} \mathrm{C}\right)$ occurred by $\langle 110\rangle$ type shear. The calculated value for $\Delta \sigma_{\mathrm{sh}}$ for this material corresponded very closely to the $\sigma_{n}$ value. The general applicability of this correlation warrants further checking.

Values for $\sigma_{\mathrm{n}}$ and the yleld strength, $\sigma_{\mathrm{y}}$, can be used to define the limits of a stress-particle size zone in which time-dependent notch sensitivity occurs. Essentially unimodal $\gamma^{\prime}$ size distributions occurred for the sheet 
materlals aged at $1500^{\circ} \mathrm{F}\left(816^{\circ} \mathrm{C}\right), 1600^{\circ} \mathrm{F}\left(871^{\circ} \mathrm{C}\right)$, and $1700^{\circ} \mathrm{F}\left(927^{\circ} \mathrm{C}\right)$. As a consequence, $\sigma_{\mathrm{n}}$ and $\sigma_{\mathrm{y}}$ values could be plotted directly onto a stress-average particle-size graph (shown in Figure 30 for data obtained at $1200^{\circ} \mathrm{F}\left(649^{\circ} \mathrm{C}\right.$ ). The stress range over which time-dependent notch sensitivity occurred decreased with increasing $y^{\prime}$ particle size. None of the heat-treated sheet materials evaluated contained $\gamma^{\prime}$ large enough so they were not suscentible to timedependent notch sensitivity.

For materials with bimodal $\gamma^{\prime}$ size distributions, it was necessary to derive an "average" $\gamma^{\prime}$ size in order to represent the notch-sensitive behavior on the stress-particle size diagram. The "multiple" aged sheet material contalned a size distribution of this type, with volume fractions and average sizes, respectively, as follows: $0.19-3000 \AA$ and $0.25-430 \AA$ (Table IV). An average size of $770 \AA$ (volume fraction 0.44 ) was calculated by the following averaging method derived from Equation (4):

$$
\left[\frac{1}{D\left(\sqrt{V_{f}}-1\right)}\right] \ln \left(\frac{0.82 D}{4 b}\right)=\sum_{1}^{1}\left[\frac{1}{D_{i}\left(\frac{1}{V_{f_{i}}}-1\right)} \ln \left(\frac{0.82 D_{i}}{4 b}\right)\right] .
$$

Based on the data for material with unimodal $\gamma^{\prime}$ size distribution (Figure 28), one with the calculated average particle size would exhibit values of 130 and and $50 \mathrm{ksi}\left(896\right.$ and $345 \mathrm{MN} / \mathrm{m}^{2}$ ) for $\sigma_{\mathrm{y}}$ and $\sigma_{\mathrm{n}}$, respectively. The measured values were 125 and $60 \mathrm{ksi}\left(862\right.$ and $419 \mathrm{MN} / \mathrm{m}^{2}$ ). Thus good agreement was obtained for $\sigma_{y}$ but not for $\sigma_{n}$. This was not unexpected because the averaging technique was based on an equation which describes the increase in CRS when dislocations by-pass $\gamma^{\prime}$ by Orowan looping. This mechanism controlled yielding $\left(\sigma_{\mathrm{y}}\right)$ but not 
creep (1.e., $\left.\sigma_{n}\right)$. Thus an alternative method was required to determine the "average" $\gamma^{\prime}$ size when the particles were sheared during creep. Trial and error showed the following relationship to be effective:

$$
D V_{f}=\sum_{I}^{i} V_{f_{i}} D_{i}
$$

An average size of $1550 \AA$ was obtained for the multiple-aged sheet material which resulted in perfect agreement of the measured $\sigma_{n}$ value with that predicted from the unimodal $\gamma^{\prime}$ size data (Figure 29).

A similar analysis was carried out for the investment cast and bar materials using measured and estimated values for the $\gamma^{\prime}$ particle sizes and volume fractions (Table IV). These values were known less exactly than was the case for the sheet materials. In addition, as previously described, considerable ranges of $\gamma^{\prime}$ particle sizes occurred. Because of this the stress-particle size relationships evident at $1200^{\circ} \mathrm{F}\left(649^{\circ} \mathrm{C}\right)$ should be considered with some caution (Figure 29). For a given average particle size, the yleld strengths for the bar and cast materials were greater than for the sheet material. As previously discussed, several factors, including differences in the $\gamma^{\prime}$ volume fraction, contributed to these differences. More significant, $\sigma_{n}$ values for the bar materlal were considerably higher (about 1.5 times) than for the sheet and investment cast materials with the same average $\gamma^{\prime}$ size. This can primarily be attributed to differences in the notched specimen geometry (Figures 3, 4, and 5). Triaxial stresses, introduced by the circumferential notches In the bar specimens, considerably reduced the effective stress in the creeptested notched specimens and thereby gave higher $\sigma_{n}$ values than was the case 
for the edge-notched (blaxial stress) sheet and investment-cast specimens. It might also be noted that the notched specimens of the bar materials had $K_{t}$ 's of 8 , while for the sheet materials, the $K_{t}$ 's were greater than 20 . However, this difference probably had little effect on the $\sigma_{n}$ values. Previous research for sheet materials [24], demonstrated that time-dependent notch sensitivity is as severe for a $K_{t}$ of 3 as $1 t$ is for larger values. The explanation is that as long as the stress concentration is large enough to raise the stress at the base of the notch above the yield strength then creep relaxation from the yleld strength, which determines the notch sensitivity, is essentially independent of the actual $\mathrm{K}_{\mathrm{t}}$ value.

It can be readily seen from the stress-particle size diagram (Figure 29) why the bar with the "multiple" age was the only material tested which exhibited little or no time-dependent notch sensitivity (Table II, Figure 15). Based on a calculated "average" $\gamma^{\prime}$ size of $2315 \AA$ (Table IV), extrapolation of the stress-particle size curves indicates a value of about $110 \mathrm{ks} 1\left(758 \mathrm{MN} / \mathrm{m}^{2}\right)$ for $\sigma_{n}$. This value is only slightly less than the yield strength of $128 \mathrm{ksi}$ $\left(882 \mathrm{MN} / \mathrm{m}^{2}\right)$. As a consequence, as was demonstrated experimentally, this material could be expected to exhibit little susceptibility to notch sensitivity at $1200^{\circ} \mathrm{F}\left(649^{\circ} \mathrm{C}\right)$.

The above discussion of stress-particle size zones related to the timedependent notch sensitivity at $1200^{\circ} \mathrm{F}\left(649^{\circ} \mathrm{C}\right)$. The $\sigma_{y}$ and $\sigma_{\mathrm{n}}$ values defining the Iimits of the zone vary with the temperature. As observed experimentally, $\sigma_{n}$ can be expected to increase with decreasing temperature due to decreasing creep resistance. The yield strength of Udimet 700 changes very little with 
temperature from room temperature to about $1300^{\circ} \mathrm{F}\left(704^{\circ} \mathrm{C}\right)$. Thus lowering the temperature from $1200^{\circ} \mathrm{F}\left(649^{\circ} \mathrm{C}\right)$ decreases the stress range over which timedependent notch sensitivity occurs. However, more significantly, the lower the temperature the longer the time period at which time-dependent notch sensitivity becomes evident. In fact, it is probable that time-dependent notch sensitivity would cease to become a problem for service temperatures much below about $1000^{\circ} \mathrm{F}\left(538^{\circ} \mathrm{C}\right)$. The effect of increasing the temperature above $1200^{\circ} \mathrm{F}$ $\left(649^{\circ} \mathrm{C}\right)$ on the stress-particle size zone for time-dependent notch sensitivity is complex. The values for $\sigma_{\mathrm{n}}$ and $\sigma_{\mathrm{y}}$ decrease rapidly with increasing temperature above about $1300^{\circ} \mathrm{F}\left(704^{\circ} \mathrm{C}\right)$. More importantly, temperature-activited creep processes, such as climb and recovery, become important along with significant growth of the $\gamma^{\prime}$ precipitate. All of these factors caused the deformation to become homogeneous and thereby eliminated time-dependent notch sensitivity. Stress-average particle size zones characterizing the time-dependent edgenotch sensitivity at $1000^{\circ} \mathrm{F}\left(538^{\circ} \mathrm{C}\right)$ for sheet Modified Waspaloy and Waspaloy (Figures 30 and 31), were derived from the data obtained from previous studies $[1,2,5]$. These alloys were strengthened by $\gamma^{\prime}$ with volume fractions of 0.095 and 0.235 , respect1vely. It was possible to define the approximate limits of the zone for Modified Waspaloy. However, time-dependent notch sensitivity was not observed from the notched specimen rupture tests that were carried out [5]. This occurred becouse the tests were not conducted (entirely) within the limits of the stress-particle size zone. At the lower test temperatures, where the notch sensitivity is observed, many of the tests were above the yield strengths [the heat treated materials had relatively low yield-to-tensile-strength ratios, 
about 0.5$) \mathrm{J}$. In the tests that were conducted below the yield strengths, the test times were sufficiently long so that growth of the $\gamma^{\prime}$ crused the dislocation mechanism to change to looping, i.e., the particles grew beyond the limits of the stress-particle size zone where time-dependent notch sensitivity occurs.

From comparison of the stress-particle size zones for the three materials (Figure 29, 30, and 31), it is evident that they differ even though the general. characterisitics are the same. For Modifled Waspaloy and Waspaloy small $y^{\prime}$ particles were sheared by $\langle 10>$ type dislocations. For Udimet 700 , shearing also occurred during creep by $\left\langle 110>\right.$ type dislocations. However, as the $\gamma^{\prime}$ partlcle size was Increased, <ll2> type shear became operative. This was the princtpal reason why the zone for time-dependent notch sensitivity extended to much larger particle sizes for Udimet 700 than was the case for the other two materials.

The mechanisms by which dislocation by-passed the $\gamma^{\prime}$ were also dependent on the precipltate volume fraction. For Modified Waspaloy, the $\gamma^{\prime}$ particles were by-passed by both cross-sIlp and Orowan looplng, whereas for the higher volume fraction alloys, Waspaloy and Udimet 700, only Orowan looping occurred. (Note however, that the CRSS for cross-silp and looping are the same (Orowan stress) as they are both dependent on the ability of dislocations to bow between particles.)

The yield strengths increased with the $\gamma^{\prime}$ volume fraction in the alloys studied. This occurred due to an increase in the volume fraction per se along with other factors, the most significant being the increase in strength asgociated with higher alloyed matrices $\left(\Delta \sigma_{m}\right.$ for Modifled Waspaloy, Waspaloy, and 
Udimet 700 were estimated to be about 44,62 , and $85 \mathrm{ksi}$, respectively ( 304 , 428, and $587 \mathrm{MN} / \mathrm{m}^{2}$ ). 


\section{SUMMARY OF RESULTS}

A research program has been carried out to characterize the susceptibility of sheet, bar, and cast Udimet 700 to time-dependent notch sensitivity in the temperature range $1000^{\circ}$ to $1600^{\circ} \mathrm{F}\left(538^{\circ}-871^{\circ} \mathrm{C}\right)$. The results were evaluated in terms of the mechanical characteristics and the dislocation motion mechanisms operative.

Time-dependent notch sensitivity occurred at the lower test temperatures for several heat treatments of all test materials. The severity of the timedependent notch sensitivity decreased with increasing test temperature so that none was observed at $1600^{\circ} \mathrm{F}\left(871^{\circ} \mathrm{C}\right)$. The susceptibility to notch sensitivity was dependent on the notched specimen geometry and the $\gamma^{\prime}$ size distribution. The sheet and cast materials behaved similarly as they were both evaluated using edge-notched "flat" specimens (notches introduced biaxial stress concentrations). The bar materials, with circumferential notches, were less susceptible to notch sensitivity. This was attributed to the fact that the notches introduced triaxial stress concentrations which acted to reduce the effective stress relative to the nominal and, thereby, increased the notched specimen rupture strengths.

The severity of the notch sensitivity decreased with increasing average $\gamma^{\prime}$ size in the heat treated materials. The $\gamma^{\prime}$ size distributions varied with section size and aging treatment. The greater the section size the larger the $\gamma^{\prime}$ that resulted on air cooling from the solution treatment temperature. The more severe the aging treatment (higher temperature and/or Ionger time) the 
greater the coarsening of $\gamma^{\prime}$ during aging. Growth of $\gamma^{\prime}$ followed $t^{1 / 3}$ diffusion-controlled kinetics. The activation energy for growth varied from about 130 to $60 \mathrm{kcal} / \mathrm{mole}$ for unstressed exposure at temperatures from $1500^{\circ}$ to $1975^{\circ} \mathrm{F}\left(816^{\circ}-1079^{\circ} \mathrm{C}\right)$, respectively.

In tensile and creep-rupture tests, variations in the $\gamma^{\prime}$ size distribution resulted in changes in the dislocation motion mechanisms. In tensile tests, $<110>$ type dislocations sheared $\gamma^{\prime}$ particles smaller then a critical size (about $500 \AA$ in diameter). Larger particles were by-passed by Orowan looping. These mechanisms resulted in localized and homogeneous deformation, respectively. In creep-rupture tests at the lower temperatures, small particles were sheared by $<110>$ type dislocations. With increasing $\gamma^{\prime}$ particle size, $<112>$ type shear became operative. Correspondingly, the deformation became less localized with increasing particle size. For all of the heat treated materials that exhibited time-dependent notch sensitivity, the deformation was localized and the $\gamma^{\prime}$ particles were sheared during creep by either $\langle 110\rangle$ or $<112>$ type dislocations. At the higher temperatures, recovery processes became operative during creep, the deformation was homogeneous and, no timedependent notch sensitivity was observed.

The results of the investigation were consistent with the following concepts developed from former investigations of nickel-base alloys containing smaller volume fractions of precipitated particles [1-5]: (a) Time-dependent notch sensitivity occurs when notched specimens are loaded below the approximate 0.2 percent smooth specimen offset yield strength and, (b) The precipitate particles are sheared by dislocations and the deformation is localized. Time- 
dependent notch sensitivity has not been observed, under any test conditions for which the deformation is homogeneous.

The data obtained were used to define the limits of a stress-average particle size zone for which time-dependent notch sensitivity occurs for Udimet 700. Determination of the zone using theoretical concepts was examined. Limited success indicated that, with some modification, theoretical definition of the zone is feasible. This would allow prediction of the time-dependent notch sensitive behavior precipitation strengthened alloys with little or no mechanical testing. 
REFERENCES

1. Wilson, D. J., "Sensitivity of the Creep-Rupture Properties of Waspaloy Sheet to Sharp-Edged Notches in the Temperature Range $1000^{\circ}-1400^{\circ} \mathrm{F}$," Trans. ASME, J. Basic Eng. 24 (1972), No. 1, pp. 13-21.

2. Wilson, D. J., "The Dependence of the Notch Sensitivity of Waspaloy at $1000^{\circ}-1400^{\circ} \mathrm{F}$ on the Gamma Prime Phase," Trans. ASME, J. Eng. Mats. Tech. 25 (1973), No. 1, pp. 15-20.

3. Cullen, T. M., and J. W. Freemen, "The Mechanical Properties at $800^{\circ}$, $1000^{\circ}$, and $1200^{\circ}$ of Two Superalloys Under Consideration for Use in the Supersonic Transport," prepared under Grant No. NsG-124-61 (NASA CR-92) for NASA by The University of Michigan, Ann Arbor, September 1964.

4. Wilson, D. J., "Relationship of Mechanical Characteristics and Microstructural Features to the Time-Dependent Edge-Notch Sensitivity of Inconel 718 Sheet," Trans. ASME, J. Eng. Mats. Tech. 25 (1973), No. 2, pp. 112-123.

5. Wilson, D. J., and A. Ferrari, "Time-Dependent Edge-Notch Sensitivity of Oxide and Gamma Prime Dispersion Strengthened Sheet Materials at $1000^{\circ}$ to $1800^{\circ} \mathrm{F}\left(538^{\circ}-982^{\circ} \mathrm{C}\right)$," NASA CR-121123 (1972).

6. Bigelow, W. C., J. A. Amy, and L. O. Brockway, "Electron Microscope Identification of the Gamma Prime Phase of Nickel-Base Alloys," Proc. ASTM, Vol. 56, p. $945,1956$.

7. Kriege, O. H., and J. M. Barris, "The Chemical Partitioning of Elements in Camma Prime Separated from Precipitation Hardened Nickel-Base Alloys," Trans. ASM 62 (1969), pp. 195-200.

8. Van Der Molen, E. H., J. M. Oblak, and O. H. Kriege, "Control of Gamma Prime Particle Size and Volume Fraction in High Temperature Superalloy Udimet 700," Met. Trans. 2 (1971), pp. 1627-1633.

9. Decker, R. F., "Strengthening Mechanisms in Nickel-Base Superalloys," presented at the Steel Strengthening Symposium, Zurich, Switzerland (1969).

10. Wilson, F. G., and F. B. Pickering, "Some Aspects of the Deformation of an Age-Hardened Austenitic Steel," JISI 207 (1969), pp. 490-499.

11. Kotual, P. S., "The Microstructure of Superalloys, " Metallography 1 (1969), pp. $251-285$. 
12. Gleiter, M., and E. Hornbogen, "Precipitation Hardening by Coherent Particles," Mat. Sci. Eng. 2 (1967/68), pp. 285-302.

13. Kear, B. H., G. R. Leverant, and J. M. Oblak, "An Analysis of CreepInduced Intrinsic/Extrinsic Fault Pairs in a Precipitation Hardened Nickel-Base Alloy," Trans. ASM 62 (1969), pp. 639-650.

14. Leverant, G. R., and B. H. Kear, "The Mechanism of Creep in Gamma Prime Precipitation-Hardened Nickel-Base Alloys at Intermediate Temperatures," Met. Trans. I (1970), pp. 491-498.

15. Kear, B. H., J. M. Oblak, and A. F. Giamei, "Stacking Faults in Gamma Prime Ni 3 (Al, Ti) Precipitation Hardened Nickel-Base Aloys," Met. Trans. $\underline{1}(1970)$, pp. $2477-2486$.

16. Leverant, G. R., B. H. Kear, and J. M. Oblak, "Creep of Precipitation Hardened Nickel-Base Alloy Single Crystals at High Temperatures, "Met. Trans. 4 (1973), pp. 355-362.

17. Kocks; U. F., "The Relation Between Polycrystal Deformation and Single Crystal Deformation," Met. Trans. I (1970), No. 5, pp. 1121-1159.

18. Blackburn, M. J., and J. C. Williams, "Strength, Deformation Modes and Fracture in Titanium-Aluminum Alloys," Trans. ASM 62 (1969), pp. 398-409.

19. Dreshfield, R. L., and J. F. Wallace, "The Effect of Alloying Gama and Gamma Prime in Nickel-Base Superalloys," NASA CR-120940 (1972).

20. Gerold, V., and H. Haberkorn, "On the Critical Resolved Shear Stress of Solid Solutions Containing Coherent Precipitates, " Phys. Status Solidi 16 (1966), pp. 675-684.

21. Copley, S. M., and B. H. Kear, "A Dynamic Theory of Coherent Precipitation Hardening with Application to Nickel-Base Superalloys," Trans. AIME 239 (1967), pp. 984-992.

22. Ashby, M. F., "Physics of Strength and Plasticity," Mass. Inst. Tech. Press (1969), pp. 113-131.

23. Ashby, M. F., "The Hardening of Metals by Non-Deforming Particles, " $\underline{\text {. }}$ Metallkunde 52 (1964), pp. 5-17.

24. Wilson, D. J., J. W. Freeman, and P. D. Goodell, "Sensitivity of the Creep-Rupture Properties of Nickel-Base Superalloy Steel to Sharp-Edged Notches in the Temperature Range $1000^{\circ}-1400^{\circ} \mathrm{F}, "$ NASA CR-1263 (1969). 
TABLE I

SNOOTH AND EDGE-HOTCHFD $\left(K_{\mathrm{t}}>20\right)$ SPECIMEN TENSILE AND CREEP-RUPTVRE PFOPERTTES AT $1000^{\circ}$ to $1200^{\circ} \mathrm{P}\left(538^{\circ}-871^{\circ} \mathrm{C}\right)$ FOR $0.025-I N C H\left(0.64 \mathrm{~ms}\right.$ ) THICK IDTMET TOO SHEET SOLUTION TREATED $1 / 2$ HOUR AT $2150^{\circ} \mathrm{F}$ (1177 ${ }^{\circ} \mathrm{C}$ ) ANT AGED

\begin{tabular}{|c|c|c|c|c|c|c|c|c|c|c|c|c|c|}
\hline \multicolumn{8}{|c|}{ Smooth Specimens } & \multicolumn{6}{|c|}{ Notched Specimens } \\
\hline \multirow{2}{*}{\multicolumn{2}{|c|}{$\begin{array}{c}\text { Test } \\
\text { Temperature } \\
\frac{\left({ }^{\circ} \mathrm{F}\right)}{\left({ }^{\circ} \mathrm{C}\right)}\end{array}$}} & \multicolumn{2}{|c|}{ Stress } & \multirow{2}{*}{$\begin{array}{l}\text { Rupture } \\
\text { Time } \\
\text { (hr) }\end{array}$} & \multirow{2}{*}{$\begin{array}{c}\text { Elong. } \\
(\%)\end{array}$} & \multirow{2}{*}{$\begin{array}{l}\text { R.A. } \\
\text { (\$) }\end{array}$} & \multirow{2}{*}{$\begin{array}{c}\text { M1nimun } \\
\text { Creep Rate } \\
(\$ / \mathrm{hr})\end{array}$} & \multicolumn{2}{|c|}{$\begin{array}{c}\text { Time } \\
\text { Temperature } \\
\end{array}$} & \multicolumn{2}{|c|}{ Stress } & \multirow{2}{*}{$\begin{array}{l}\text { Rupture } \\
\text { Time } \\
(\mathrm{hr})\end{array}$} & \multirow{2}{*}{$\begin{array}{c}\mathrm{N} / \mathrm{s} \\
\text { Strength } \\
\text { Ratio }\end{array}$} \\
\hline & & (ksi) & $\left(\mathrm{MN} / \mathrm{m}^{2}\right)$ & & & & & $\left({ }^{\circ} \mathrm{F}\right)$ & $\left(0^{\circ} \mathrm{C}\right)$ & (k81) & $\left(\mathrm{MN} / \mathrm{m}^{2}\right)$ & & \\
\hline & \multicolumn{13}{|c|}{ Aged 3 Hours at $1500^{\circ} \mathrm{F}\left(816^{\circ} \mathrm{C}\right)$} \\
\hline 1000 & 538 & 210 & 758 & $1199 \mathrm{sh}^{2}$ & 3.2 & - & $-v e^{c}$ & 1000 & 538 & 70 & 483 & $2539 \mathrm{ph}$ & 0.66 \\
\hline \multirow[t]{4}{*}{1200} & 649 & 162.7 & 1122 & tensile $e^{\mathrm{d}}$ & 7.9 & 16 & - & 1100 & 593 & 90 & 621 & $46.3 \mathrm{ph}$ & 0.74 \\
\hline & & 80 & 552 & $110 \mathrm{sh}$ & - & - & - ve & & & 70 & 483 & $253 \mathrm{ph}$ & 0.72 \\
\hline & & 80 & 552 & $34.1 \mathrm{sh}$ & - & - & - ve & & & 50 & 345 & $90.0 \mathrm{ph}$ & 0.48 \\
\hline & & 60 & 414 & $353 \mathrm{ph}^{\mathrm{b}}$ & - & - & -ve & & & & & & \\
\hline \multirow{2}{*}{1400} & & & & & & & & 2200 & 649 & $\begin{array}{l}249.7 \\
80\end{array}$ & 1032 & $\begin{array}{c}\text { tensile } \\
10.5\end{array}$ & 0.92 \\
\hline & 760 & $\begin{array}{l}50 \\
35\end{array}$ & $\begin{array}{l}345 \\
241\end{array}$ & $\begin{array}{l}10.2 \mathrm{sh} \\
8513\end{array}$ & $\begin{array}{l}0.5 \\
2.0\end{array}$ & - & $\overline{0} .000031$ & & & $\begin{array}{l}80 \\
60\end{array}$ & $\begin{array}{l}552 \\
414\end{array}$ & $\begin{array}{l}10.5 \\
37.0\end{array}$ & $\begin{array}{l}0.81 \\
0.67\end{array}$ \\
\hline \multirow{4}{*}{1600} & 871 & 30 & 207 & 405 & 2,2 & 3 & 0.00069 & & & 40 & 276 & $589 \mathrm{ph}$ & 0.55 \\
\hline & & & & & & & & 1400 & 760 & 30 & 207 & \multicolumn{2}{|c|}{8642 DAscontinued } \\
\hline & & & & & & & & 1600 & 871 & 30 & 207 & $126 \mathrm{ph}$ & 0.91 \\
\hline & \multicolumn{13}{|c|}{ Agsed 24 Hours at $1600^{\circ} \mathrm{F}\left(871^{\circ} \mathrm{C}\right)$} \\
\hline 1000 & 538 & 120 & 827 & 2329 & 1.0 & 7 & -ve & 1000 & 538 & 80 & 552 & 4507 & 0.67 \\
\hline $12 \infty$ & 649 & 167.0 & 1151 & $\operatorname{tensil} 1 e^{d}$ & 5.1 & 13 & - & 1100 & 593 & 90 & 621 & 199 & 0.76 \\
\hline & & $\begin{array}{r}110 \\
90\end{array}$ & 758 & 147 & 0.6 & 7 & -ve & & & 60 & 414 & $2508 \mathrm{ph}$ & 0.56 \\
\hline & & 90 & 621 & $1152 \mathrm{ph}$ & - & - & -ve & & & & & & \\
\hline 2400 & 760 & 70 & 483 & $41.8 \mathrm{ph}$ & - & - & 0.0042 & 1200 & 649 & 140.2 & 967 & tensile & 0.84 \\
\hline & 100 & 40 & 276 & 4402 & 1.9 & 6 & 0.000064 & & & 80 & 552 & 32.3 & 0.71 \\
\hline & & & & & & & & & & $\begin{array}{l}60 \\
40\end{array}$ & $\begin{array}{l}414 \\
276\end{array}$ & 58.3 & 0.54 \\
\hline 1600 & $87 i$ & 30 & 207 & 494 & 3.7 & 10 & 0.00077 & & & & & 5512 & 0.50 \\
\hline & & 20 & 138 & 2200 & 4.4 & - & 0.000050 & 1400 & $7 \in 0$ & 40 & 276 & $15.0 \mathrm{pb}$ & 0.50 \\
\hline & & & & & & & & & & 30 & 207 & 9611 D1sco & tínued \\
\hline & & & & & & ged 48 & ours at $1700^{\circ}$ & $\left.927^{\circ} \mathrm{C}\right)$ & & & & & \\
\hline 1000 & 538 & 100 & 689 & 8306 Discor & hued & & -ve & 1000 & 538 & 80 & 552 & 4955 & $>0.76$ \\
\hline 1200 & 649 & 126.2 & 870 & tensile & 4.8 & 14 & - & 1200 & 649 & 120.6 & 832 & tensile & 0.96 \\
\hline & & 90 & 621 & 82.7 & 0.9 & - & -ve & & & 70 & 483 & 41.4 & 0.76 \\
\hline & & 80 & 552 & 124 & 0.5 & 3.0 & $-v e$ & & & 60 & 414 & 1748 & 0.81 \\
\hline & & 70 & 483 & $1271 \mathrm{ph}$ & - & - & $-v e$ & & & & & & \\
\hline 2400 & 760 & 50 & 345 & 2229 & 3.4 & 7 & 0.00040 & 1400 & 760 & 50 & 345 & 3840 & 1.05 \\
\hline & & & & & & & & 1600 & & 30 & 207 & $566 \mathrm{pb}$ & 1.13 \\
\hline $16 \infty 0$ & 871 & 30 & 207 & 492 & 3.6 & 4 & -ve & & & 20 & 138 & 1157 & 0.92 \\
\hline & & & ed 4 Hour & at $1975^{\circ} \mathrm{F}$ & ${ }^{\circ} \mathrm{C}$ ) Plus & Hours & $1550^{\circ} \mathrm{F}(84)$ & P2us 1 & fours & $2400^{\circ} \mathrm{F}$ & $\left.{ }^{\circ} \mathrm{C}\right)=$ & iple" & \\
\hline 1000 & 538 & 125 & 862 & 35.1 & 1.2 & 5 & -ve & 1000 & 538 & 100 & 689 & 287 & 0.82 \\
\hline & 110 & 110 & $5787 \mathrm{D}$ & continued & & & -ve & & & 80 & 552 & $1860 \mathrm{ph}$ & 0.67 \\
\hline 1200 & 649 & 145.7 & 1004 & tensile $\mathrm{d}^{\mathrm{d}}$ & 2.2 & 6 & - & & & 70 & 483 & 9343 Disco & tinued \\
\hline & & 120 & 827 & 6.2 & 0.9 & 4 & - & 1100 & 593 & 100 & 689 & 90.2 & 0.83 \\
\hline & & 80 & 552 & 12,086 & 2.0 & 4 & -ve & & & 70 & 483 & 2855 & 0.63 \\
\hline 1400 & 760 & 70 & 483 & 92.4 & 6.2 & 10 & 0.0039 & 1200 & 649 & 124.5 & 858 & tensile & 0.85 \\
\hline & & 50 & 345 & 1378 & 3.2 & 12 & 0.00025 & & & 90 & 621 & 31.6 & 0.77 \\
\hline & & & & & & & & & & 70 & 483 & $70.0 \mathrm{ph}$ & 0.62 \\
\hline 1600 & 871 & 30 & 207 & $27^{4}$ & 3.2 & 2 & -ve & & & 70 & 483 & 63.9 & 0.62 \\
\hline & & 20 & 138 & 1320 & 0.9 & 2 & 0.000047 & & & 60 & 414 & $190 \mathrm{ph}$ & 0.55 \\
\hline & & & & & & & & 1400 & 760 & 50 & 345 & 1130 & 1.00 \\
\hline & & & & & & & & 1600 & 871 & 30 & 207 & $79.7 \mathrm{ph}$ & 0.88 \\
\hline & & & & & & & & & & $\infty$ & 138 & $833 \mathrm{ph}$ & 0.91 \\
\hline
\end{tabular}

Notes: ${ }^{a}$ sh $=$ failed at shoulder.

${ }^{b} \mathrm{ph}=$ failed at pin hole.

c -ve = negative minimum creep rate.

${ }^{\mathrm{d}} 0.2$ percent offset yield strengths at $1200^{\circ} \mathrm{F}\left(649^{\circ} \mathrm{C}\right): 3$ hours at $1500^{\circ} \mathrm{F}\left(816^{\circ} \mathrm{C}\right)-132.0 \mathrm{ksi}\left(910 \mathrm{MN} / \mathrm{m}^{2}\right) ; 24 \mathrm{hours}$ at $1600^{\circ} \mathrm{F}\left(871^{\circ} \mathrm{C}\right)$ $135.0 \mathrm{ksi}\left(931 \mathrm{MN} / \mathrm{m}^{2}\right) ; 48$ hours at $1700^{\circ} \mathrm{F}\left(927^{\circ} \mathrm{C}\right)-104.5 \mathrm{ks} 1\left(721 \mathrm{MN} / \mathrm{m}^{2}\right)$; "Multiple" $-127.0 \mathrm{ksi}\left(876 \mathrm{mN} / \mathrm{m}^{2}\right)$. 
TABLE II

SMOOTH AND CIRCUNFERENTIAL-NOTCHED $\left(K_{t}=6\right)$ ROUND SPECIMEN TENSILE AND CFEEF-RUPTUFE FROPERTIES

AT $1000^{\circ}$ to $1800^{\circ} \mathrm{F}\left(538^{\circ}-982^{\circ} \mathrm{C}\right)$ for $0.6-$ INCH $(1.5 \mathrm{~cm})$ DIAMETTER HEAT TREATED UDIMET 700 SAR

\begin{tabular}{|c|c|c|c|c|c|c|c|c|c|c|c|c|c|}
\hline & & & & th specimen & & & & & & Note & d Specim & & \\
\hline Temp & & & & $\begin{array}{c}\text { Rupture } \\
\text { Tine }\end{array}$ & Elong. & R.A. & $\begin{array}{c}\text { Min1mum } \\
\text { Creep Rate }\end{array}$ & Temp & ure & & ess & $\begin{array}{l}\text { Rupture } \\
\text { Tidee }\end{array}$ & $\begin{array}{c}\mathrm{N} / \mathrm{S} \\
\text { Strength }\end{array}$ \\
\hline$\left({ }^{\circ} \mathrm{F}\right)$ & $\left({ }^{\circ} \mathrm{C}\right)$ & (ksi) & $\left(\mathrm{MN} / \mathrm{m}^{2}\right)$ & $(h r)$ & & (q) & $(\phi / h r)$ & $\left({ }^{\circ} \mathrm{F}\right)$ & $\left({ }^{\circ} \mathrm{C}\right)$ & (kEi) & $\left(\mathrm{MN} / \mathrm{m}^{2}\right)$ & & \\
\hline & & & & & $\underline{w}$ & $r$ Quer & from $2150^{\circ}$ & $1177^{\circ} 0$ & & & & & \\
\hline & & & & & & & & 1200 & & 60 & 414 & 0.4 & \\
\hline & & & & & & & & & & 30 & 207 & $>102.3 \mathrm{t}$ & \\
\hline & & & & & & & & & & 25 & 172 & $3295 \mathrm{D} 1 \mathrm{sc}$ & tinued \\
\hline & & & & Air & ed from & $0^{\circ} \mathrm{F} \_1$ & ${ }^{\circ} \mathrm{Cl}$ and Ager & Hours & $1500^{\circ} \mathrm{F}$ & $\left.16^{\circ} \mathrm{C}\right)$ & & & \\
\hline 1000 & 538 & 170 & 1172 & 569 & 10.9 & 11 & 0.0008 & 1000 & 538 & 150 & 1034 & 305 & 0.84 \\
\hline & & & & & & & & & & 120 & 827 & 2332 & 0.72 \\
\hline 1200 & 649 & 191.5 & 1320 & tensile $e^{a}$ & 12.7 & 14 & - & & & 100 & 689 & 4226 D1s & tinued \\
\hline & & 130 & 896 & 231 & 3.5 & 5 & 0.0019 & & . & & & & \\
\hline & & 110 & 758 & 1823 & 3.6 & 4 & 0.00013 & 1100 & 593 & 210 & 758 & 218 & 0.70 \\
\hline & & 80 & 552 & 6746 Disco & ued & & 0.000037 & & & 85 & 586 & $8044 \mathrm{DIs}$ & tinued \\
\hline 1400 & 760 & 80 & 552 & 290 & 8.0 & 9 & 0.016 & 1200 & 649 & 200.5 & 1382 & tensile & 1.05 \\
\hline & & 60 & 414 & 1414 & 7.9 & 11 & 0.00045 & & & 110 & 758 & 46.4 & $0.74^{\circ}$ \\
\hline 1600 & 871 & 40 & 276 & 276 & 16.4 & 19 & 0.0022 & & & $\begin{array}{l}80 \\
60\end{array}$ & $\begin{array}{l}552 \\
414\end{array}$ & $\begin{array}{l}1549 \\
6720 \text { Dis }\end{array}$ & $\begin{array}{c}0.68 \\
\text { t1 nued }\end{array}$ \\
\hline 1800 & 992 & 15 & 103 & 193 & 9.7 & 24 & 0.0068 & 1400 & 760 & 70 & 483 & 1576 & 1.11 \\
\hline & & & & Air C & d from ? & ${ }^{\circ} \mathrm{F}$ (1) & C) and Aged & Hours & $1600-F$ & $\left.T^{\circ} \mathrm{C}\right)$ & & & \\
\hline 1200 & 649 & 186.4 & 1285 & tensile & 11.0 & 11 & & 1200 & 649 & 150 & 1034 & 51.6 & $\sim 1.0$ \\
\hline & & 130 & 896 & 481 & 1.8 & 5 & 0.00090 & & & 110 & 758 & 166 & 0.79 \\
\hline & & 110 & 758 & 1352 th & - & - & 0.00020 & & & & & & \\
\hline & & & & & & & & 2400 & 760 & 80 & 552 & 119 & 1.00 \\
\hline 1400 & 760 & 80 & 552 & 156 & 4.5 & 4 & 0.016 & & & & & & \\
\hline & & 60 & 414 & 894 & 12.3 & 18 & 0.0012 & & & & & & \\
\hline 1600 & 871 & 40 & 276 & 189 & 12.7 & 20 & 0.0037 & & & & & & \\
\hline & & & Alr $\mathrm{Co}$ & from $2150^{\circ}$ & $\begin{array}{r}\left.177^{\circ} \mathrm{C}\right) \text { a } \\
\text { Plus }\end{array}$ & $\begin{array}{l}\text { Aged } \\
\text { Hours }\end{array}$ & $\begin{array}{l}\text { ure at } 1975 \\
1400^{\circ} \mathrm{F}(760\end{array}$ & $\begin{array}{l}1079^{\circ} \mathrm{C} \\
-\quad " \mathrm{Mu} \\
\end{array}$ & Lus 24 & urg at 1 & $0^{\circ} \mathrm{F}(843$ & & \\
\hline 1000 & 538 & 170 & 1172 & 558 & 10.4 & 10 & 0.0025 & 1000 & 538 & 170 & 1172 & 711 & 2.02 \\
\hline 1200 & 649 & 187.9 & 1296 & tensile ${ }^{\mathrm{a}}$ & 12.8 & 13 & - & 1200 & 649 & 204.8 & 1412 & - tensile & 1.09 \\
\hline & & 140 & 965 & 95.1 & 10.5 & 10 & 0.036 & & & 110 & 758 & 2413 & 1.00 \\
\hline & & 130 & 896 & 419 & 14.1 & 17 & 0.023 & & & 90 & 621 & $6100 \mathrm{D} 1$ & ntinued \\
\hline & & 110 & 758 & 2808 & 9.4 & 10 & 0.00047 & & & & & & \\
\hline & & & & & & & & 1400 & 760 & 68 & 469 & 5110 & 1.17 \\
\hline 1400 & 760 & 70 & 483 & 285 & 19.5 & 31 & 0.0058 & & & & & & \\
\hline & & 55 & 379 & 1612 & 9.0 & 29 & 0.00024 & 1600 & 87 & 30 & 707 & $1198 \mathrm{Di}$ & ntinued \\
\hline 1600 & 871 & 30 & 207 & 1229 & 20.2 & 22 & 0.0013 & & & & & & \\
\hline
\end{tabular}

Notes: ${ }^{8} 0.2$ percent offset yield strengths at $1200^{\circ} \mathrm{F}\left(649^{\circ} \mathrm{C}\right)$ : Alr cooled +3 hours at $1500^{\circ} \mathrm{F}\left(816^{\circ} \mathrm{C}\right)-136.5 \mathrm{ksi}\left(941 \mathrm{MN} / \mathrm{m}^{2}\right)$; al cooled +24 hours at $1600^{\circ} \mathrm{F}\left(871^{\circ} \mathrm{C}\right)-139.0 \mathrm{ksi}\left(958 \mathrm{MN} / \mathrm{m}^{2}\right)$; s.ir cooled + "Naltiple" $-128.0 \mathrm{ks}\left(883 \mathrm{MN} / \mathrm{m}^{2}\right)$.

$b_{\text {th }}=$ pulled out of threads. 
TABLE III

SWOOTH AND EDGE-IDTCHED $\left(K_{t}=18\right)$ SPECIMEN TENSILE AND CREFP-RUPTURE PROPERTIES AT $1000^{\circ}$ TO $1600^{\circ} \mathrm{F}\left(538^{\circ}-871^{\circ} \mathrm{C}\right)$ FOF $0.09-\mathrm{TMCH}\left(2.3 \mathrm{mI}\right.$ ) THICK SECTIONS OF INVESTMENT CAST UDIMET 700 SOLUTION TREATED 4 HOURB AT $2150^{\circ} \mathrm{F}$ (1177 ${ }^{\circ} \mathrm{C}$ ) AND AGED

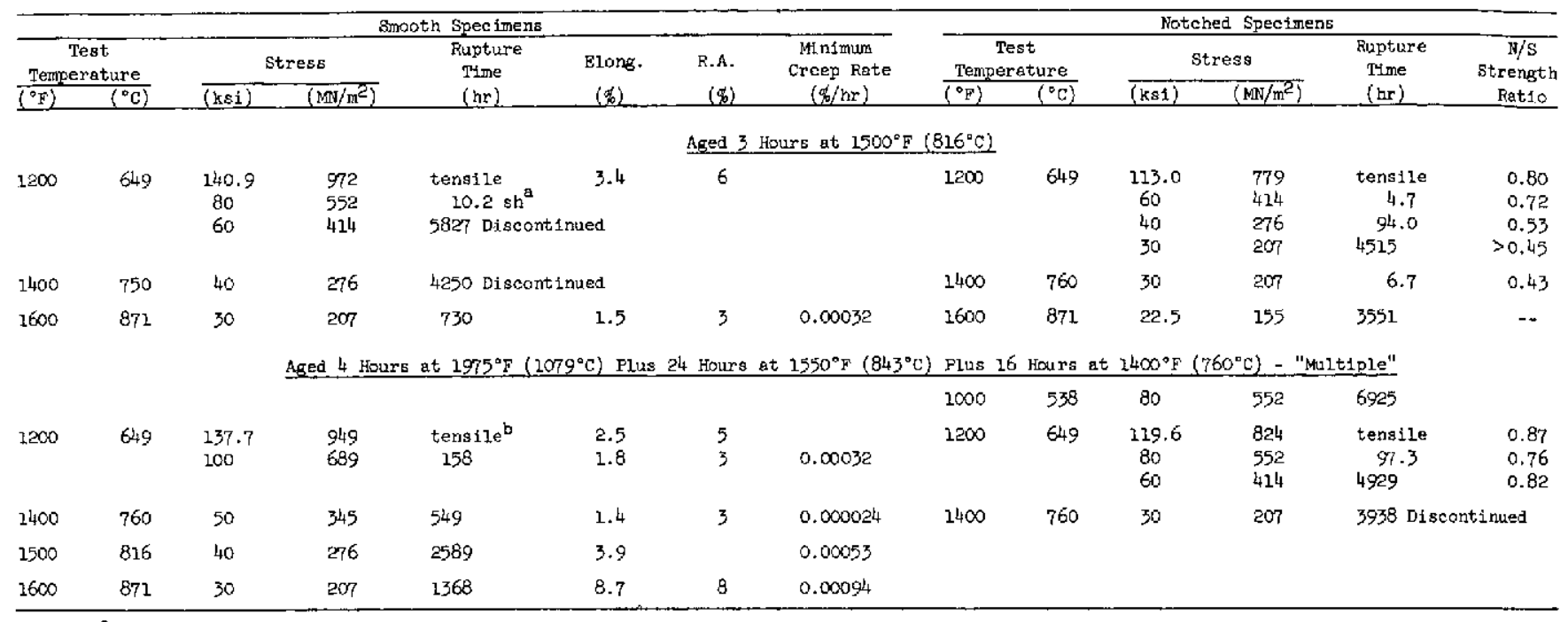

Notès: ${ }^{a} s h=$ failed at shoulder.

0.2 percent offset yield atrength at $1200^{\circ} \mathrm{F}\left(649^{\circ} \mathrm{C}\right)$ for the "multiple" aged material - $127.0 \mathrm{kB} 1\left(876 \mathrm{MN} / \mathrm{m}^{2}\right)$. 
TABLE IV

GAMMA PRIME VOLJME FRACTIONS AND SIZE DISTRIBUTIONS FOR UDIMET 70

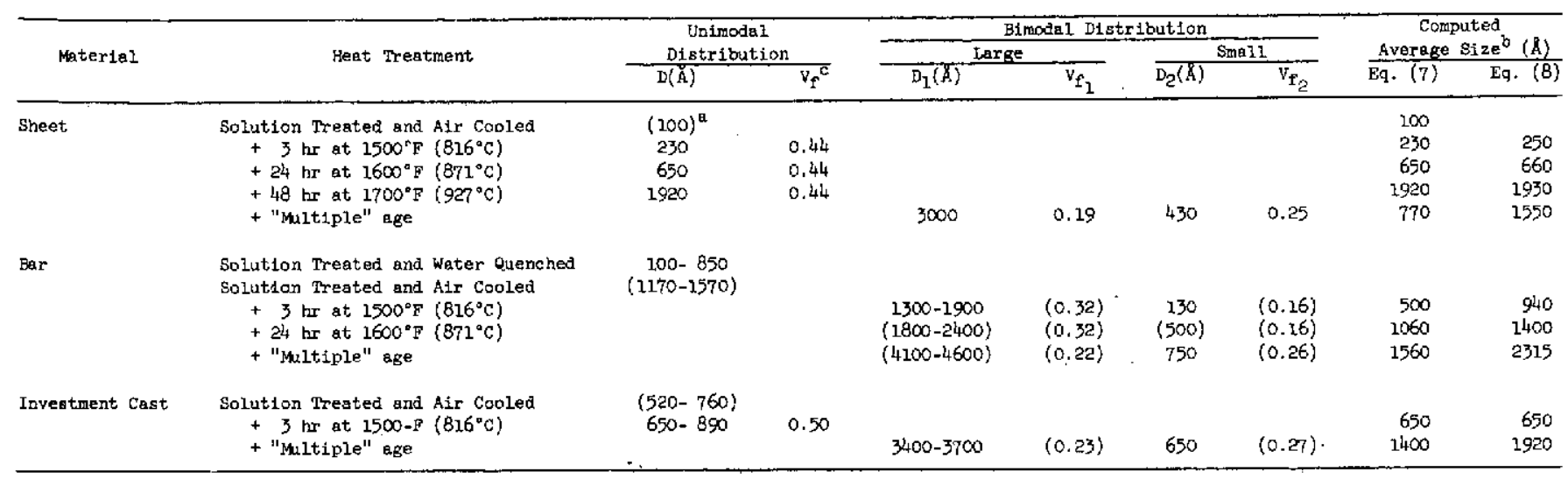

Notes: ${ }^{a}$ Values in parentheses were estimated.

b Averages calculated using Eqs. (7) and (8). In the latter case, the $y^{\prime}$ sizes were first corrected for growth during notehed specimen testa at $1200^{\circ} \mathrm{F}\left(649^{\circ} \mathrm{C}\right)$. In both cases, when a range of $\gamma^{\prime}$ sizes occurred, the lower $11 \mathrm{mit}$ was ased in the calculation.

${ }^{c} v_{f}=r$, volume fraction. 


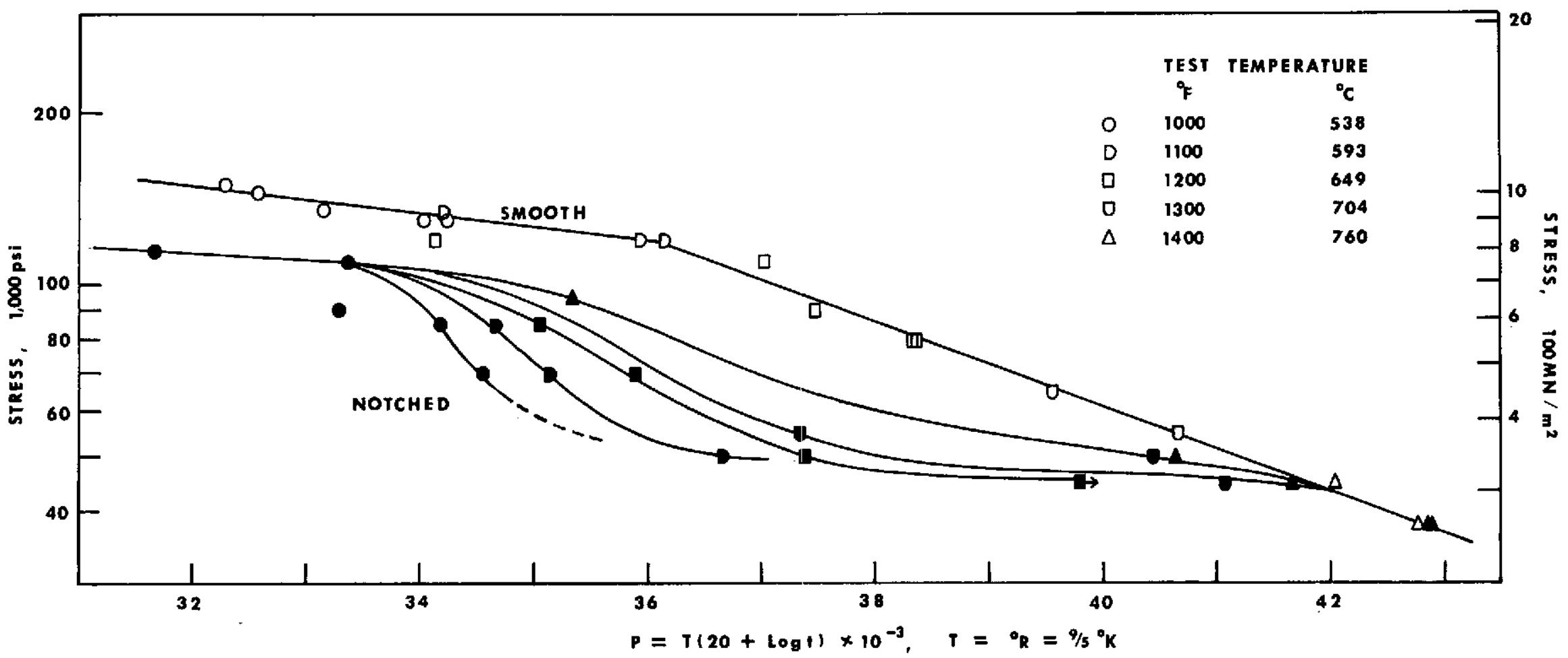

Figure 1. Larson-Miller parameter curves showing the time-temperature dependence of the rupture strengths of sheet waspaloy heat treated $1 / 2$ hour at $1975^{\circ} \mathrm{F}\left(1079^{\circ} \mathrm{C}\right.$ ) plus 16 hours at $1400^{\circ} \mathrm{F}\left(760^{\circ} \mathrm{C}\right.$ ) - Reference 1 . 


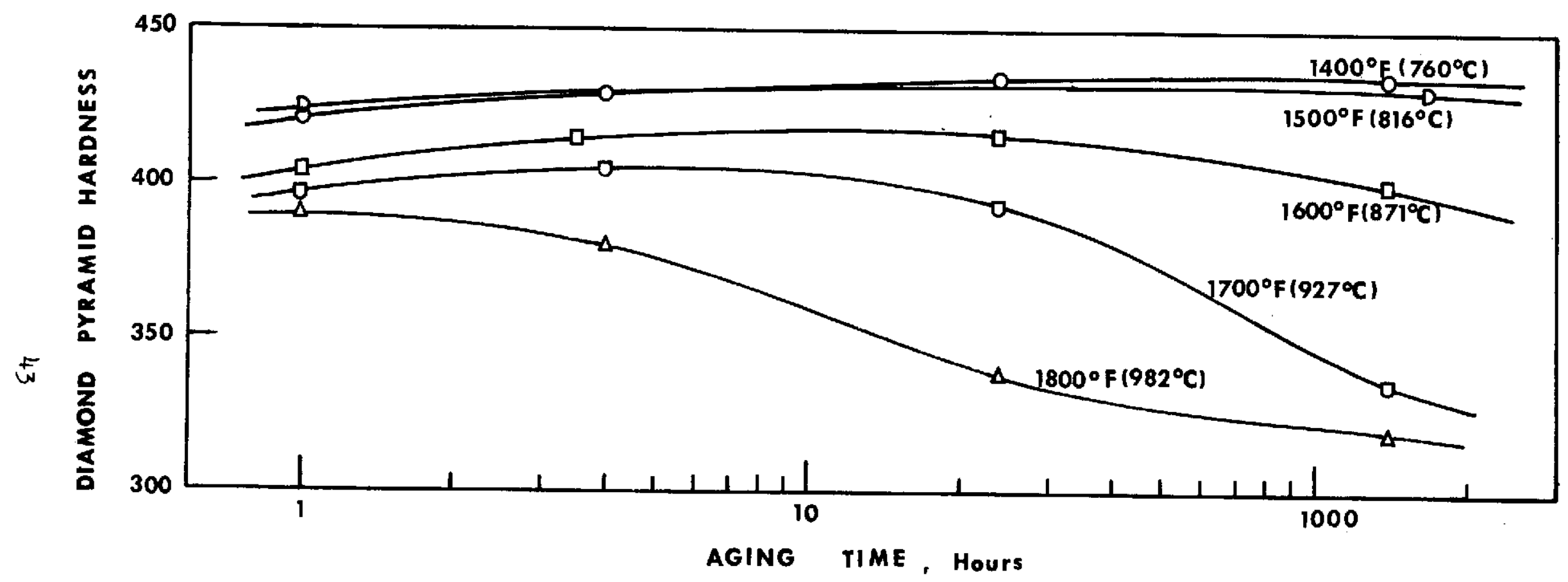

Figure 2. The effect of elevated temperature exposures on the diamond pyramid hardness of sheet Udimet 700 solution treated $1 / 2$ hour at $2150^{\circ} \mathrm{F}\left(1177^{\circ} \mathrm{C}\right)$. The aging treatments used in the study resulted in gamma prime particles smaller $\left[3\right.$ hours at $\left.1500^{\circ} \mathrm{F}\left(816^{\circ} \mathrm{C}\right)\right]$, approximately equal [24 hours at $\left.1600^{\circ} \mathrm{F}\left(871^{\circ} \mathrm{C}\right)\right]$, and larger $\left[48\right.$ hours at $\left.1700^{\circ} \mathrm{F}\left(927^{\circ} \mathrm{C}\right)\right]$ than the "critical" size (corresponding to maximum hardness). 

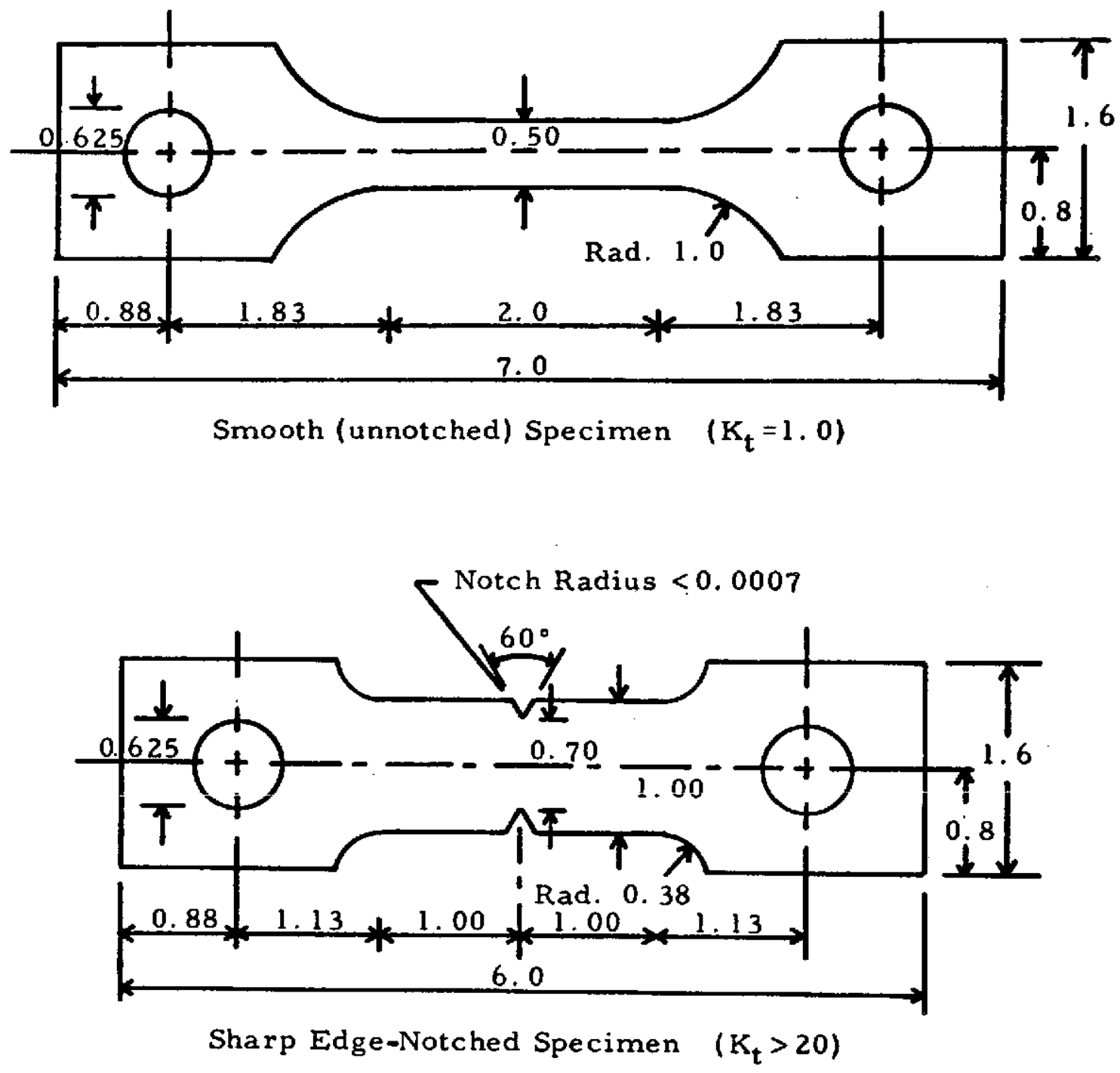

Figure 3. Types of sheet specimens (all dimensions in inches). 

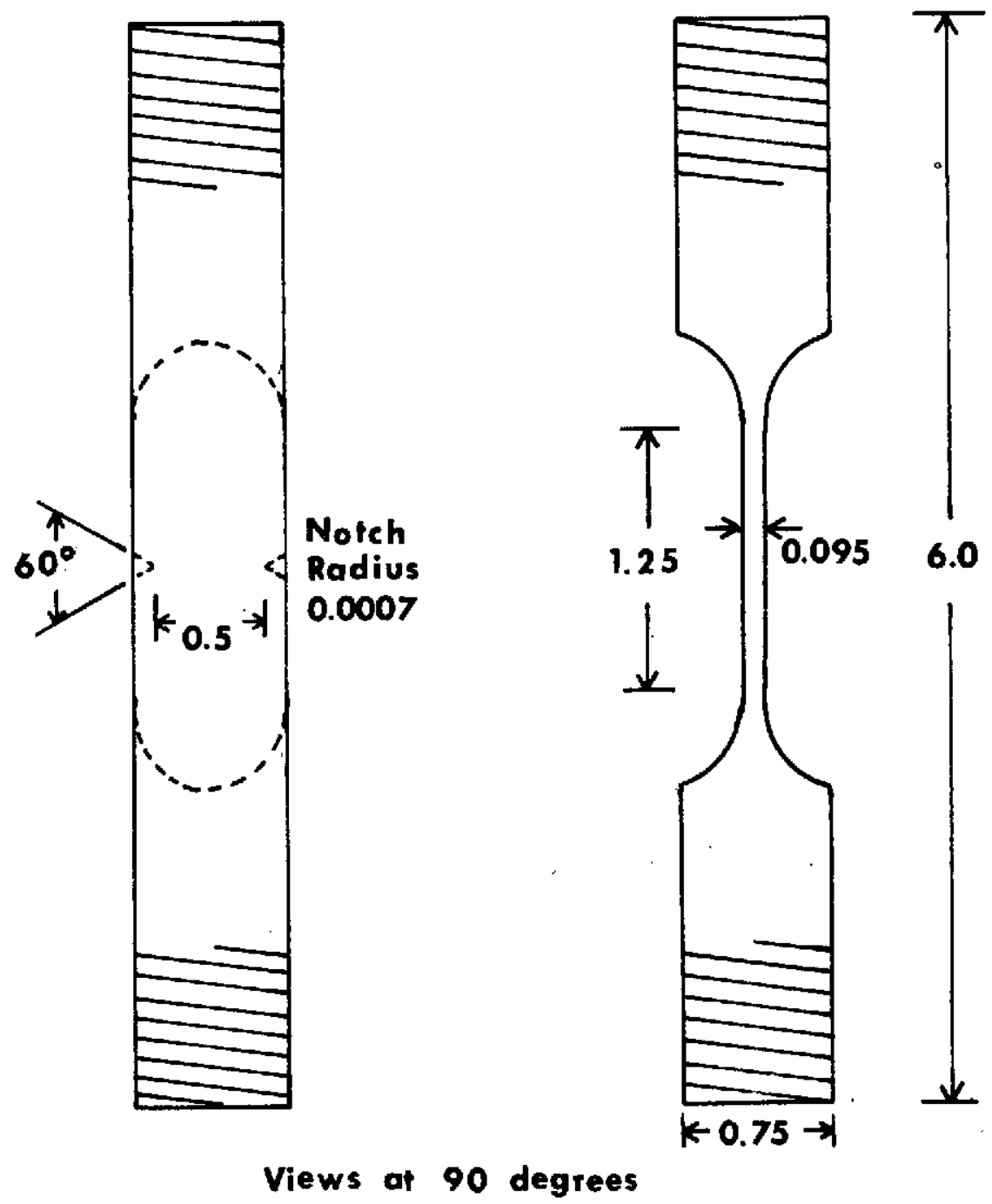

Figure 4. Smooth and edge-notched $\left(\mathrm{K}_{\mathrm{t}}=18\right)$ investment-cast specimens (all dimensions in inches). 


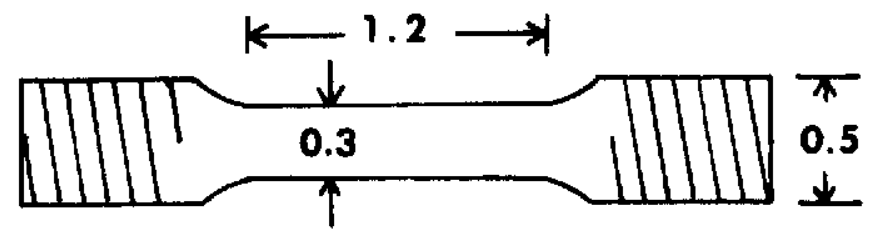

(a) Smooth Specimen

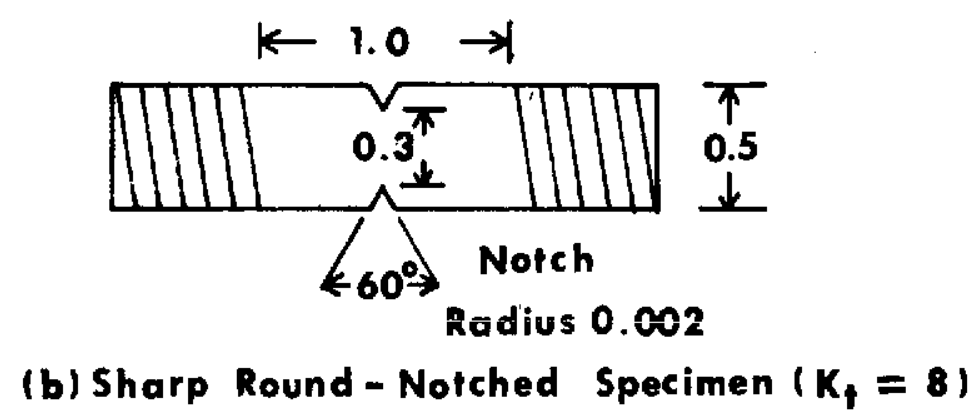

Figure 5. Round test specimens from the wrought bar (all dimensions in inches). 


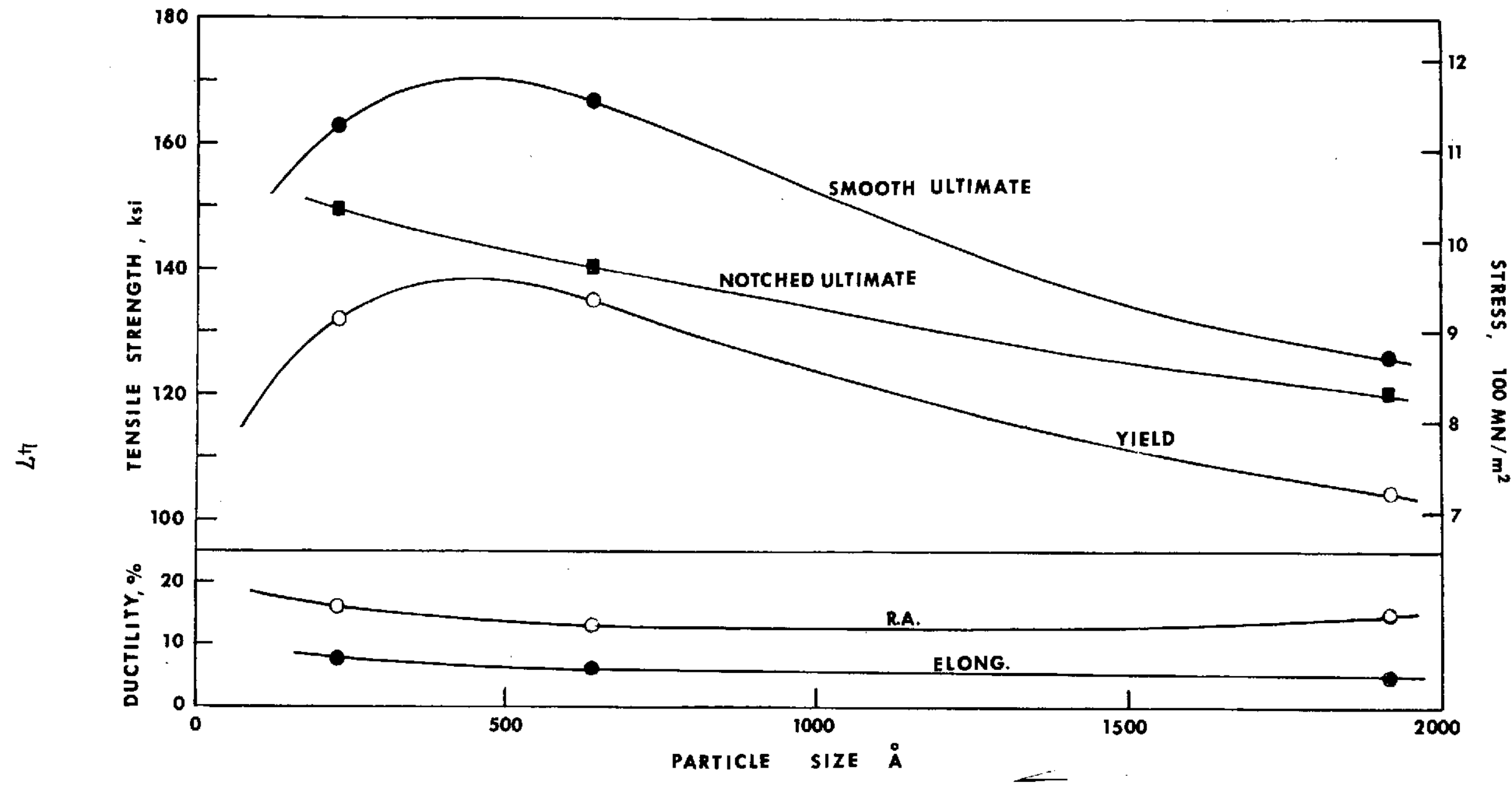

Figure 6. Tensile characteristics of solution treated and aged Udimet 700 sheet at $1200^{\circ} \mathrm{F}\left(649^{\circ} \mathrm{C}\right)$ as a function of the average gamma prime nartinle size. 


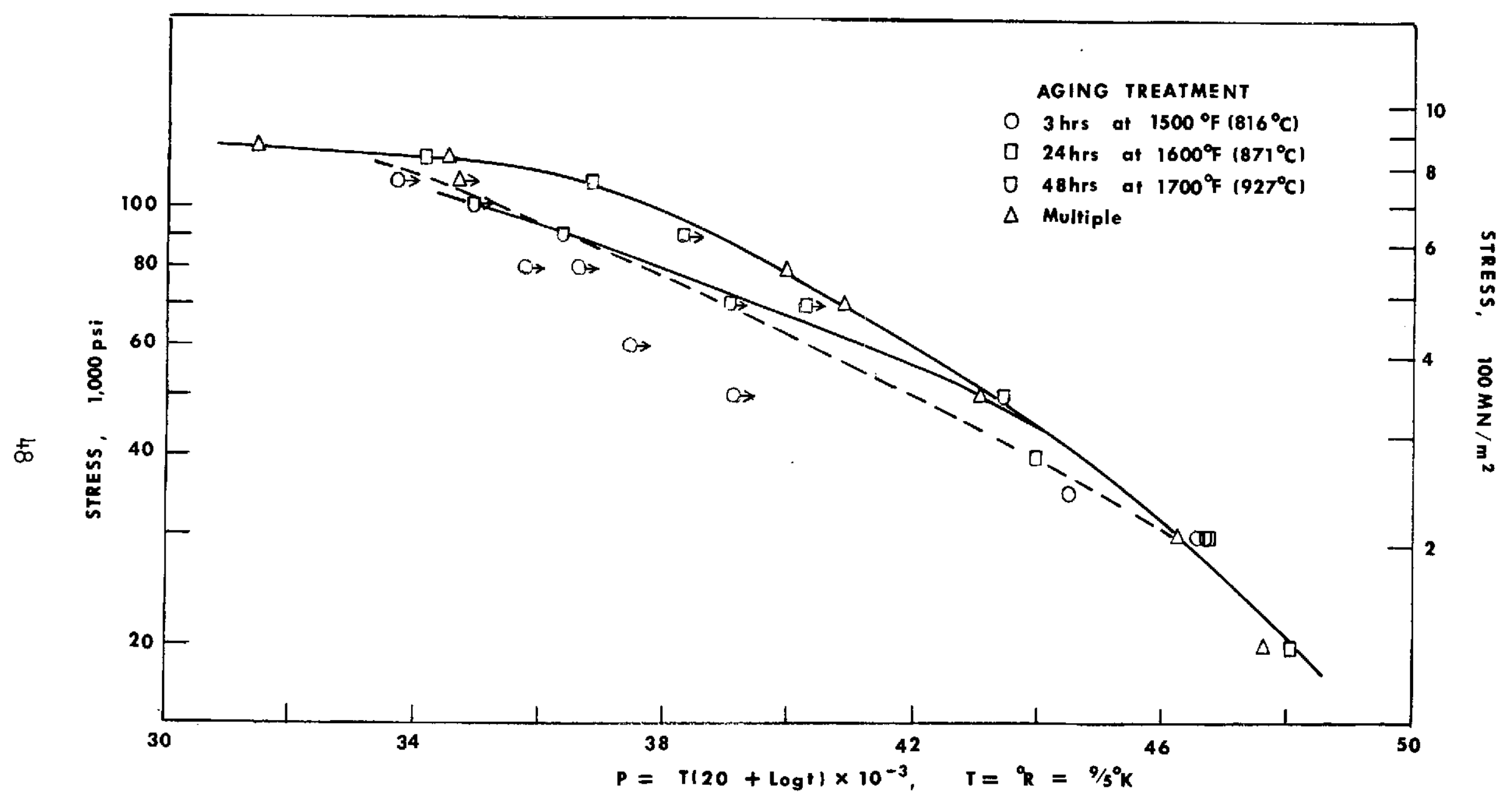

Figure 7. Larson-Miller parameter curves showing the time-temperature dependence of the smooth specimen rupture strengths of sheet Udimet 700 solution treated at $2150^{\circ} \mathrm{F}\left(1177^{\circ} \mathrm{C}\right)$ and aged. 


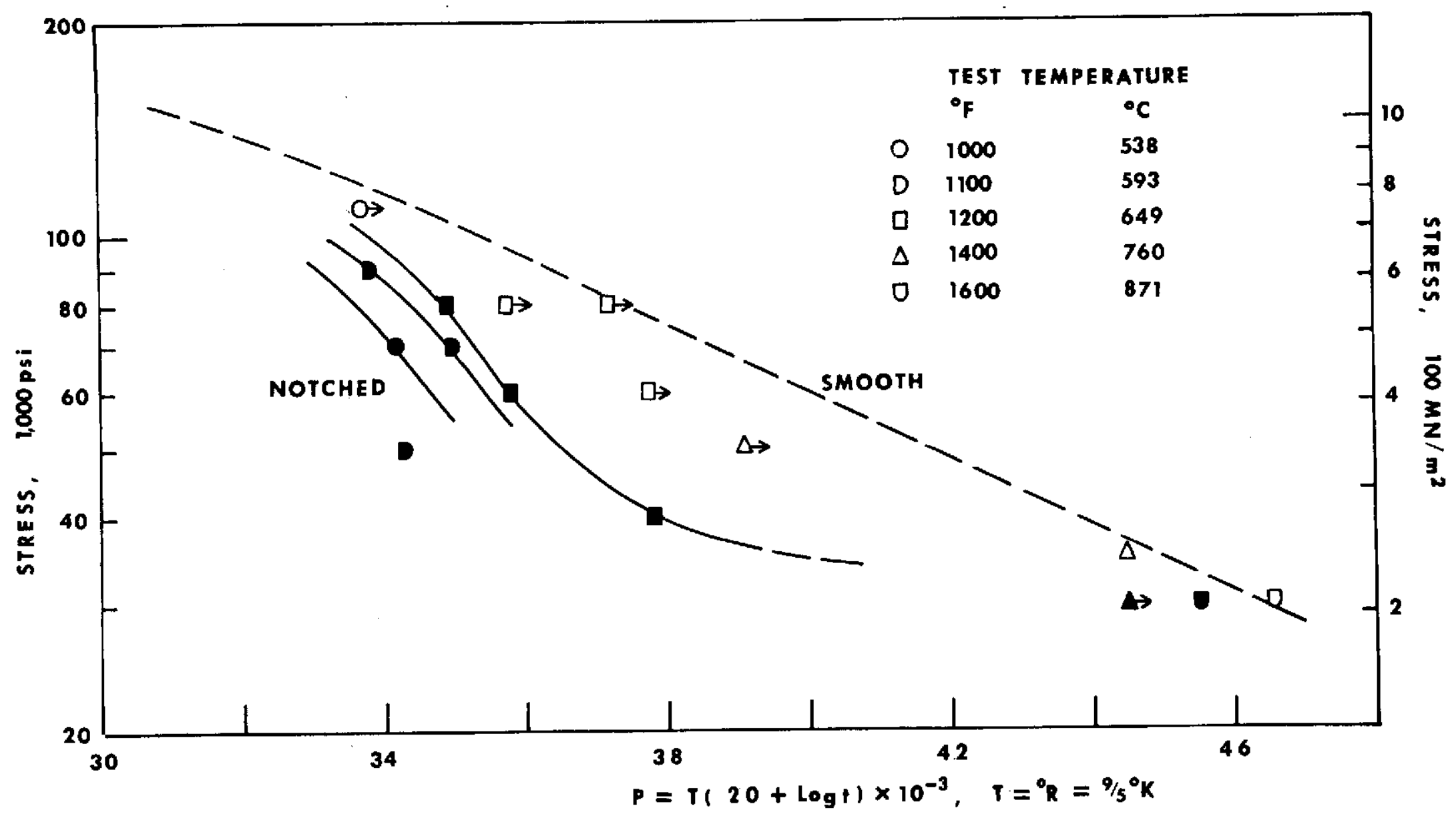

Figure 8. Larson-Miller parameter curves showing the time-temperature dependence of the rupture strengths of sheet Udimet 700 solution treated and aged 3 hours at $1500^{\circ} \mathrm{F}\left(816^{\circ} \mathrm{C}\right)$. Time-dependent notch sensitivity was observed at $1000^{\circ}, 1100^{\circ}$, and $1200^{\circ} \mathrm{F}\left(538^{\circ}, 593^{\circ}\right.$, and $\left.649^{\circ} \mathrm{C}\right)$ but not at $1400^{\circ}$ and $1600^{\circ} \mathrm{F}\left(760^{\circ}\right.$ and $\left.871^{\circ} \mathrm{C}\right)$. 


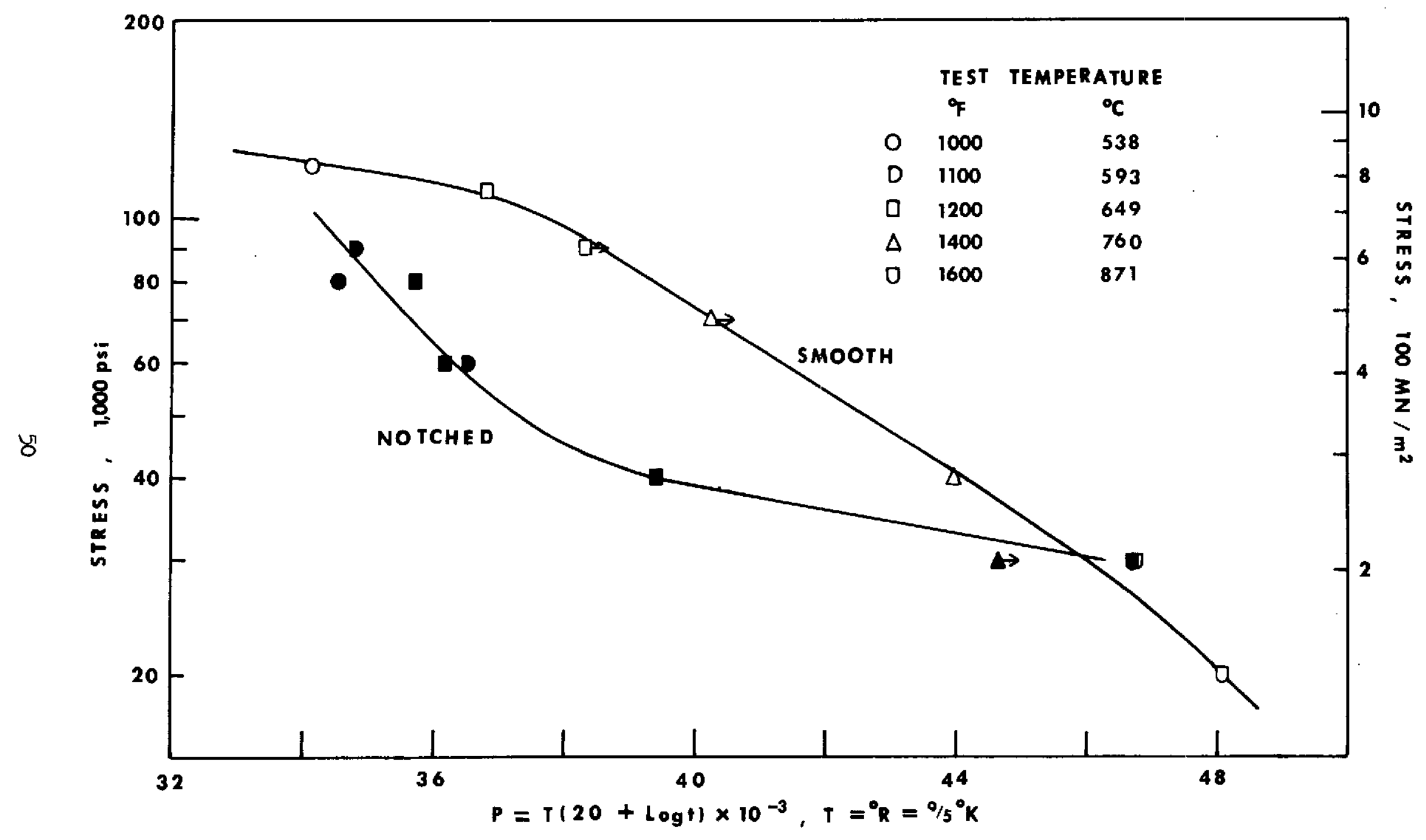

Figure 9. Iarson-Miller parameter curves showing the time-temperature dependence of the rupture strengths of sheet vdimet 700 solution treated and aged 24 hours at $1600^{\circ} \mathrm{F}\left(871^{\circ} \mathrm{C}\right)$. 


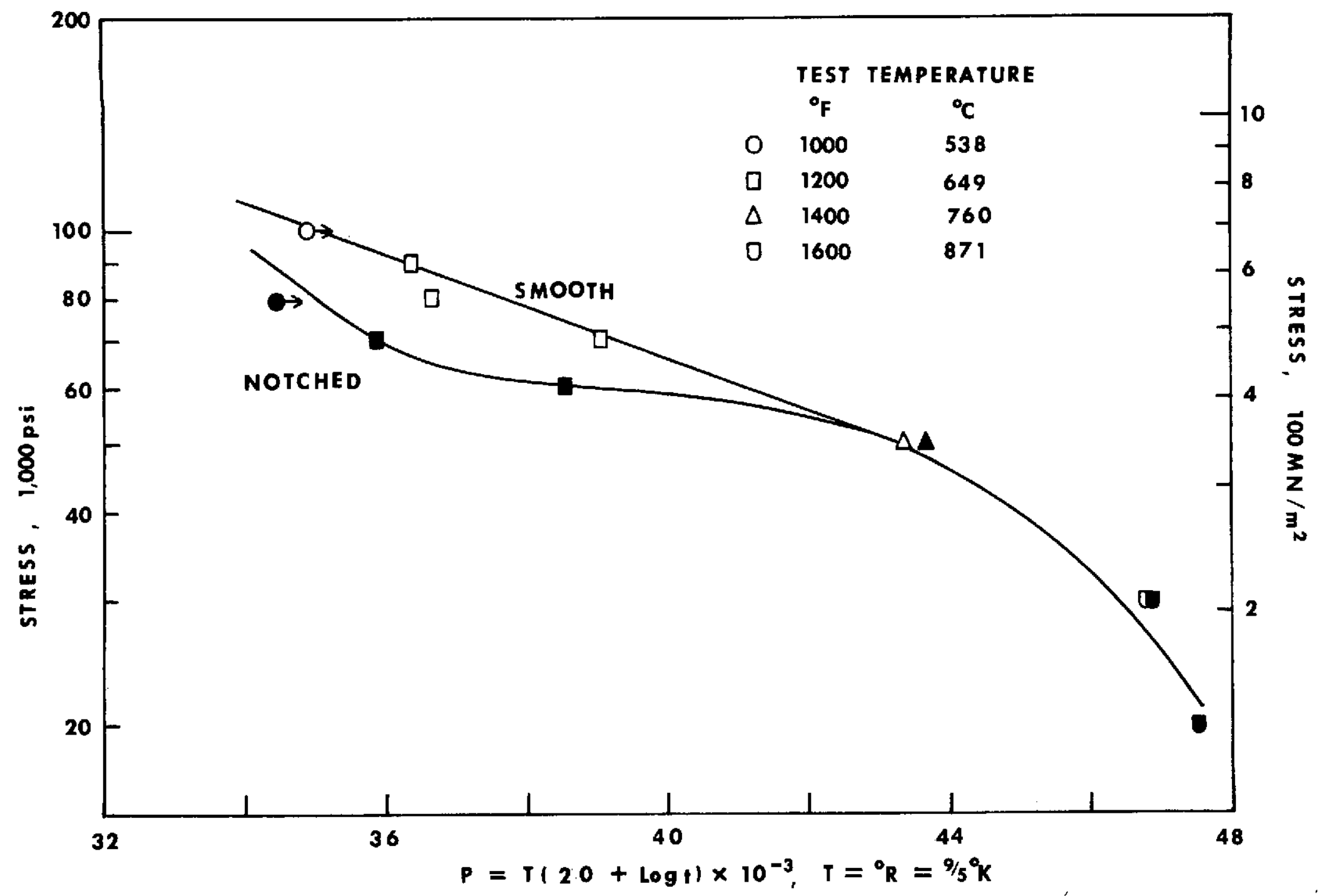

Figure 10. Larson-Miller parameter curves showing the time-temperature dependence of the rupture strengths of sheet Udimet 700 solution treated and aged 48 hours at $1700^{\circ} \mathrm{F}\left(927^{\circ} \mathrm{C}\right)$. 


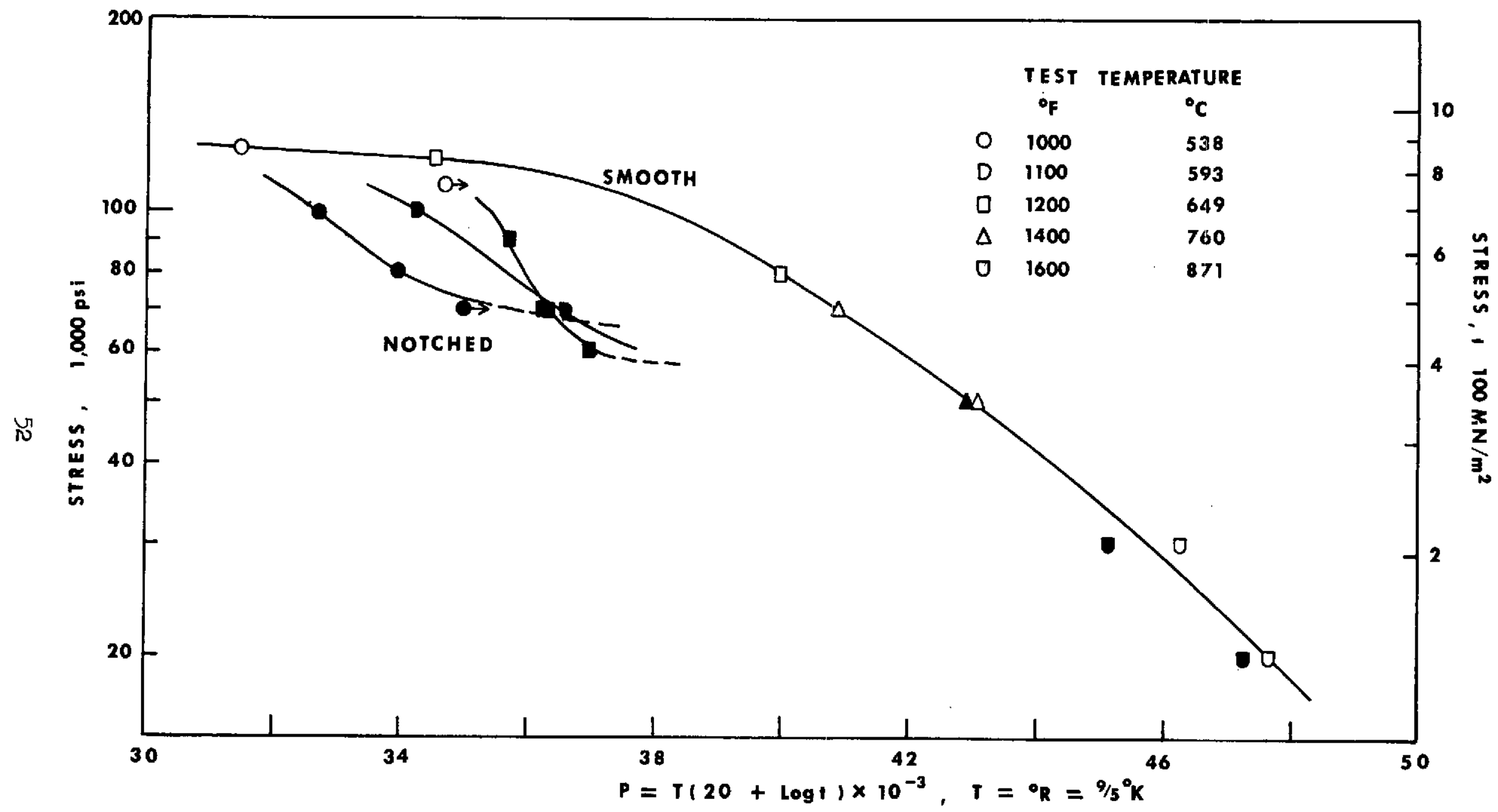

Figure 11. Larson-Miller parameter curves showing the time-temperature dependence of the rupture strengths of sheet Udimet 700 solution treated and aged 4 hours at $1975^{\circ} \mathrm{F}\left(1079^{\circ} \mathrm{C}\right)$ plus 24 hours at $1550^{\circ} \mathrm{F}$ ( $843^{\circ} \mathrm{C}$ ) plus 16 hours at $1400^{\circ} \mathrm{F}\left(760^{\circ} \mathrm{C}\right)$. 


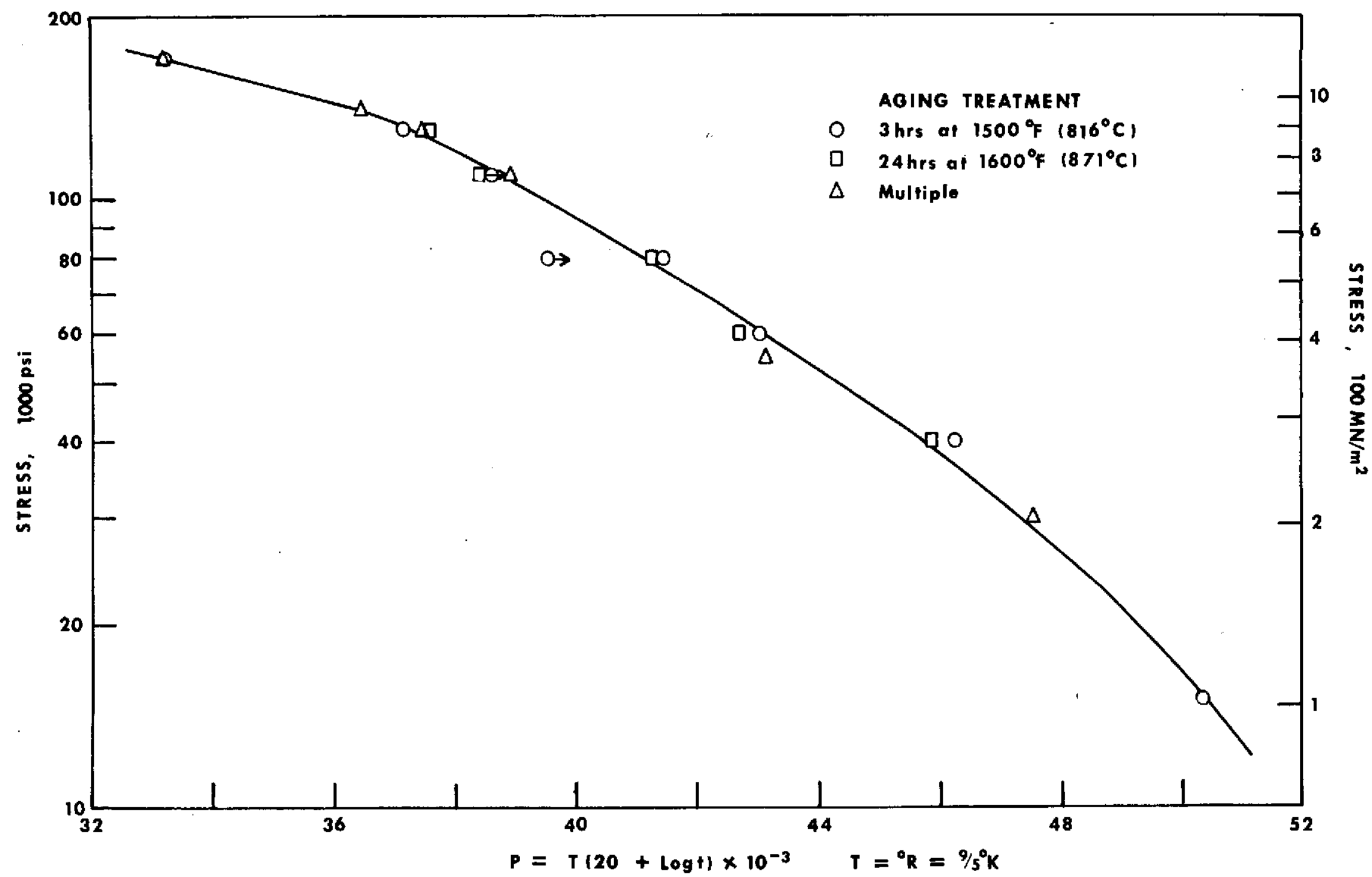

Figure 12. Larson-Miller parameter curves showing the time-temperature dependence of the rupture strengths of round smooth specimens of Udimet 700 bar solution treated at $2150^{\circ} \mathrm{F}\left(1177^{\circ} \mathrm{C}\right.$ ) and aged. 


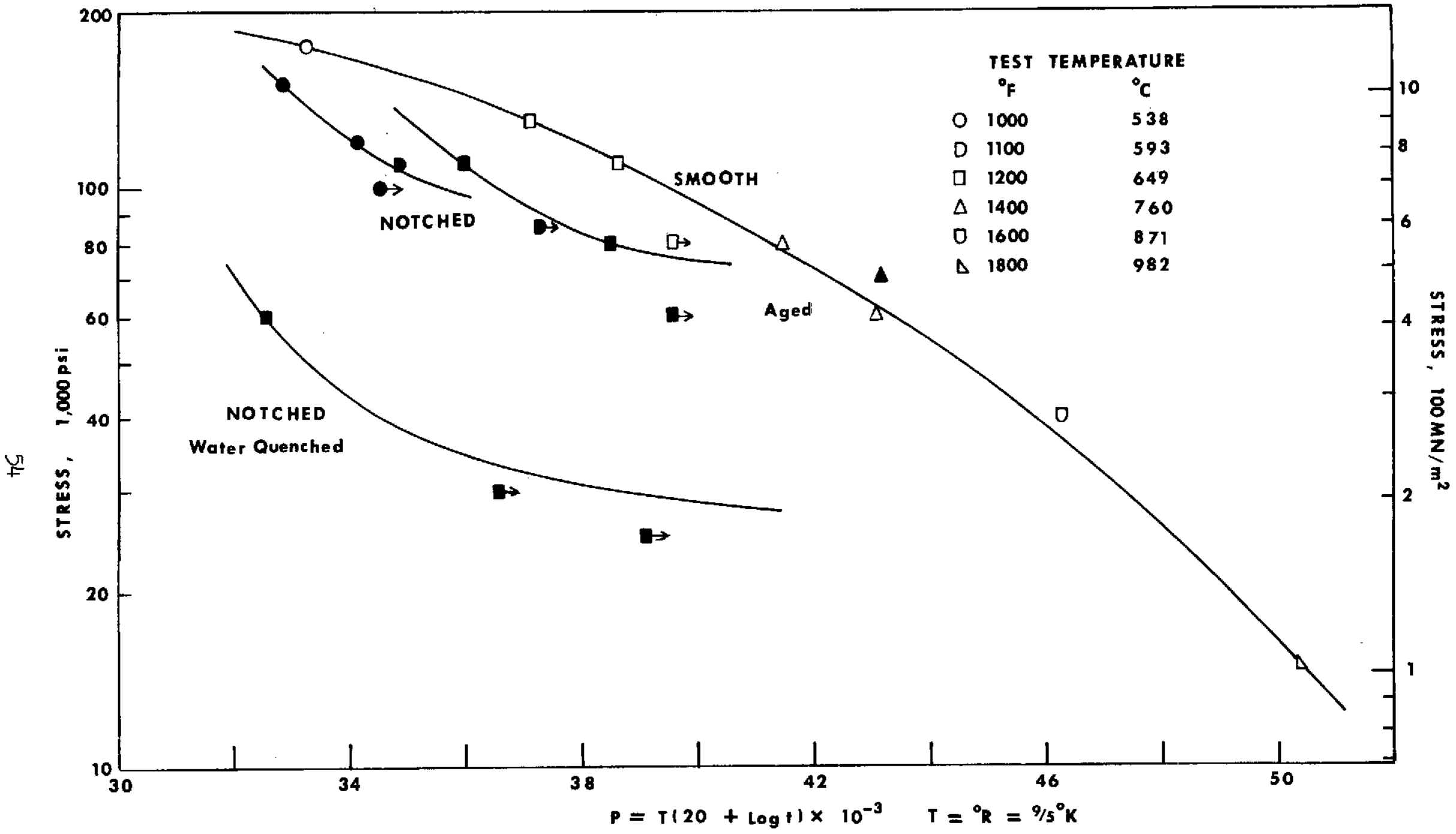

Figure 13. Larson-Miller parameter curves showing the time-temperature dependence of the rupture strengths of Udimet 700 bar solution treated, air cooled, and aged 3 hours at $1500^{\circ} \mathrm{F}\left(816^{\circ} \mathrm{C}\right)$ and bar solution treated and water quenched. Time-dependent notch sensitivity was observed at $1000^{\circ}, 1100^{\circ}$, and $1200^{\circ} \mathrm{F}\left(538^{\circ}, 593^{\circ}\right.$, and $649^{\circ} \mathrm{C}$ ). 


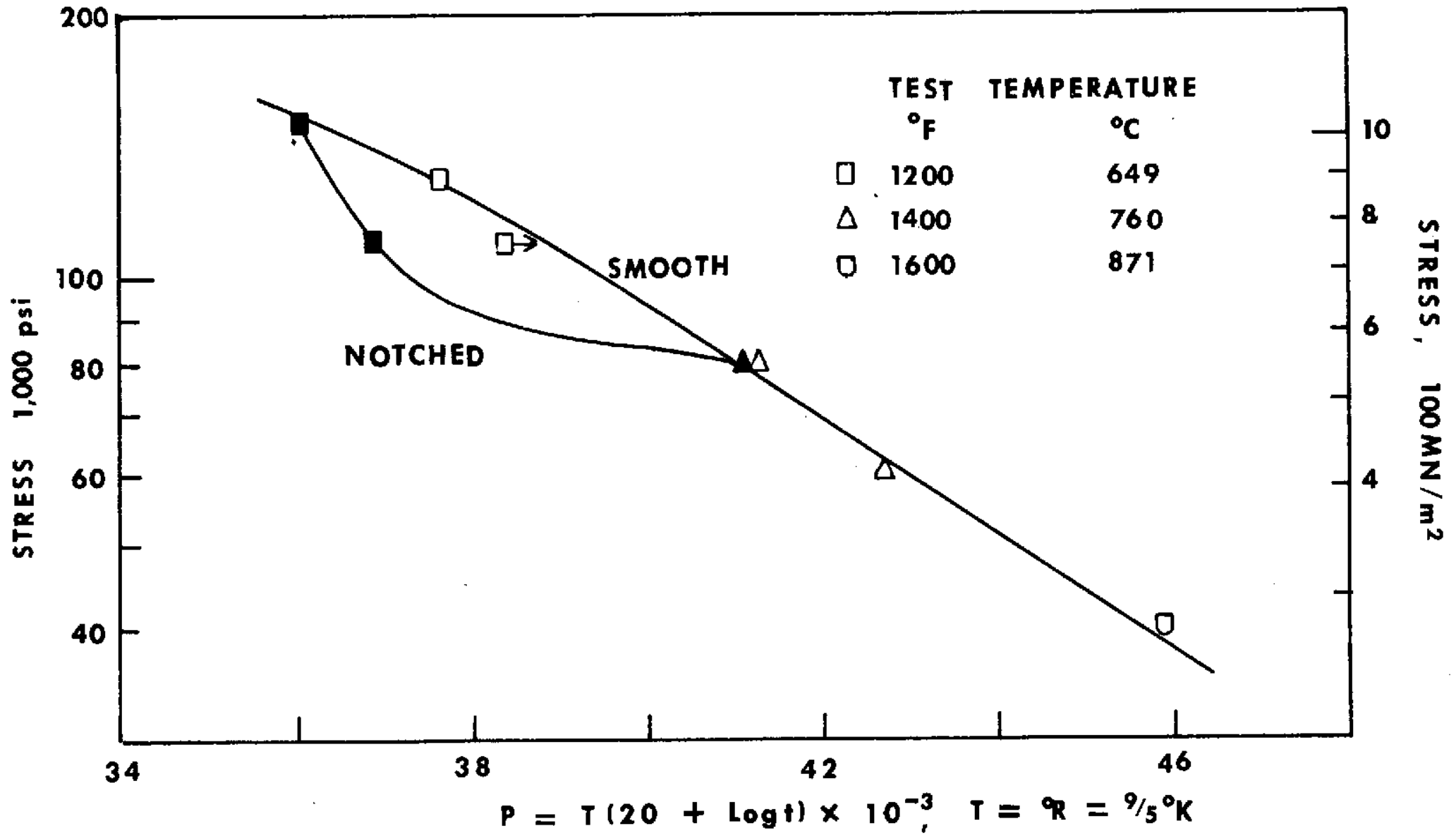

Figure 14. Larson-Miller parameter curves of the rupture strengths of Udimet 700 bar solution treated and aged 24 hours at $1600^{\circ} \mathrm{F}\left(871^{\circ} \mathrm{C}\right)$. 


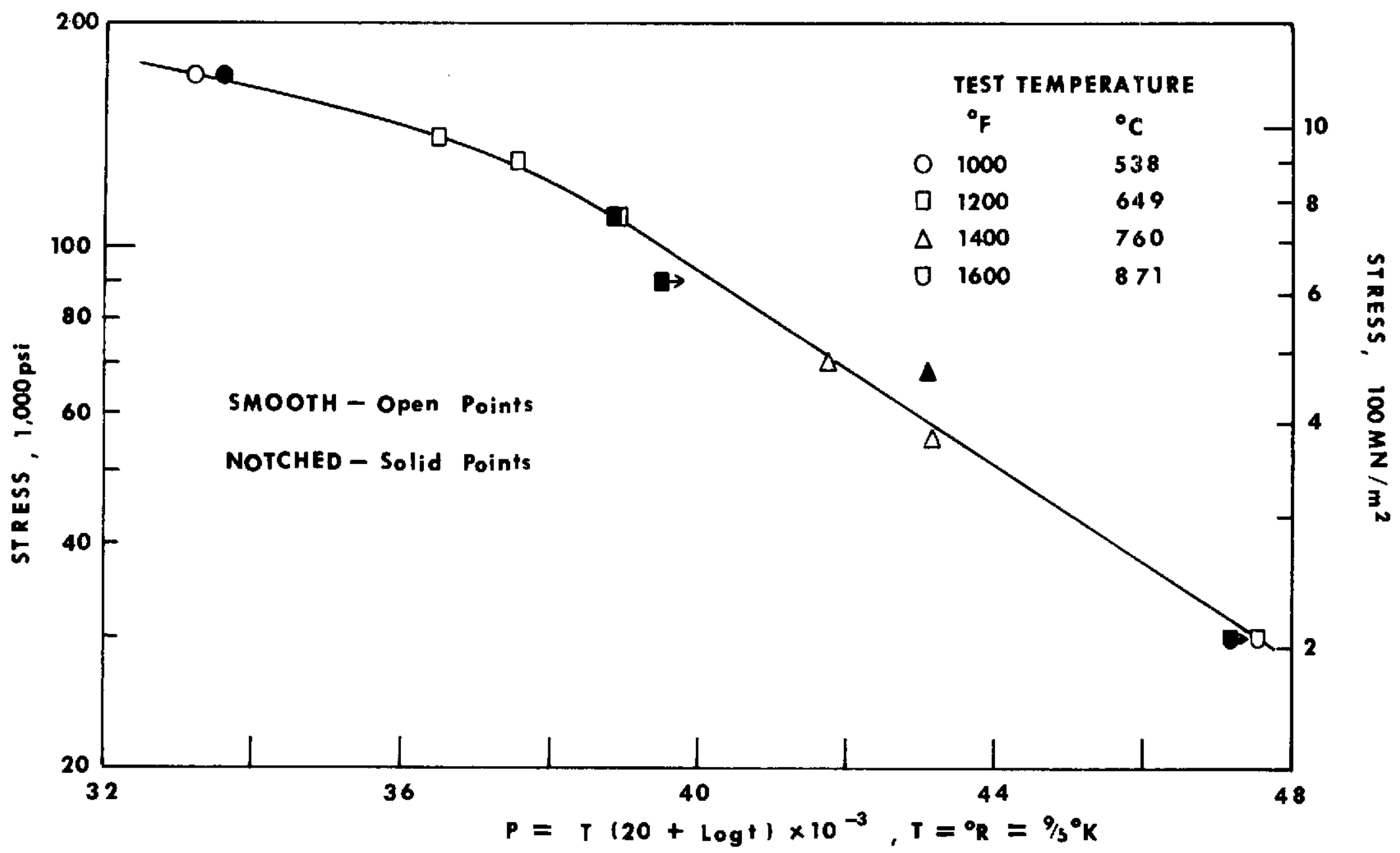

Figure 15. Larson-Miller parameter curves of the rupture strengths of Udimet 700 bar solution treated and aged 4 hours at $1975^{\circ} \mathrm{F}\left(1079^{\circ} \mathrm{C}\right)$ plus 24 hours at $1550^{\circ} \mathrm{F}\left(843^{\circ} \mathrm{C}\right)$ plus 16 hours at $1400^{\circ} \mathrm{F}$ ( $\left.760^{\circ} \mathrm{C}\right)$. Timedependent notch sensitivity was not evident from these tests. 


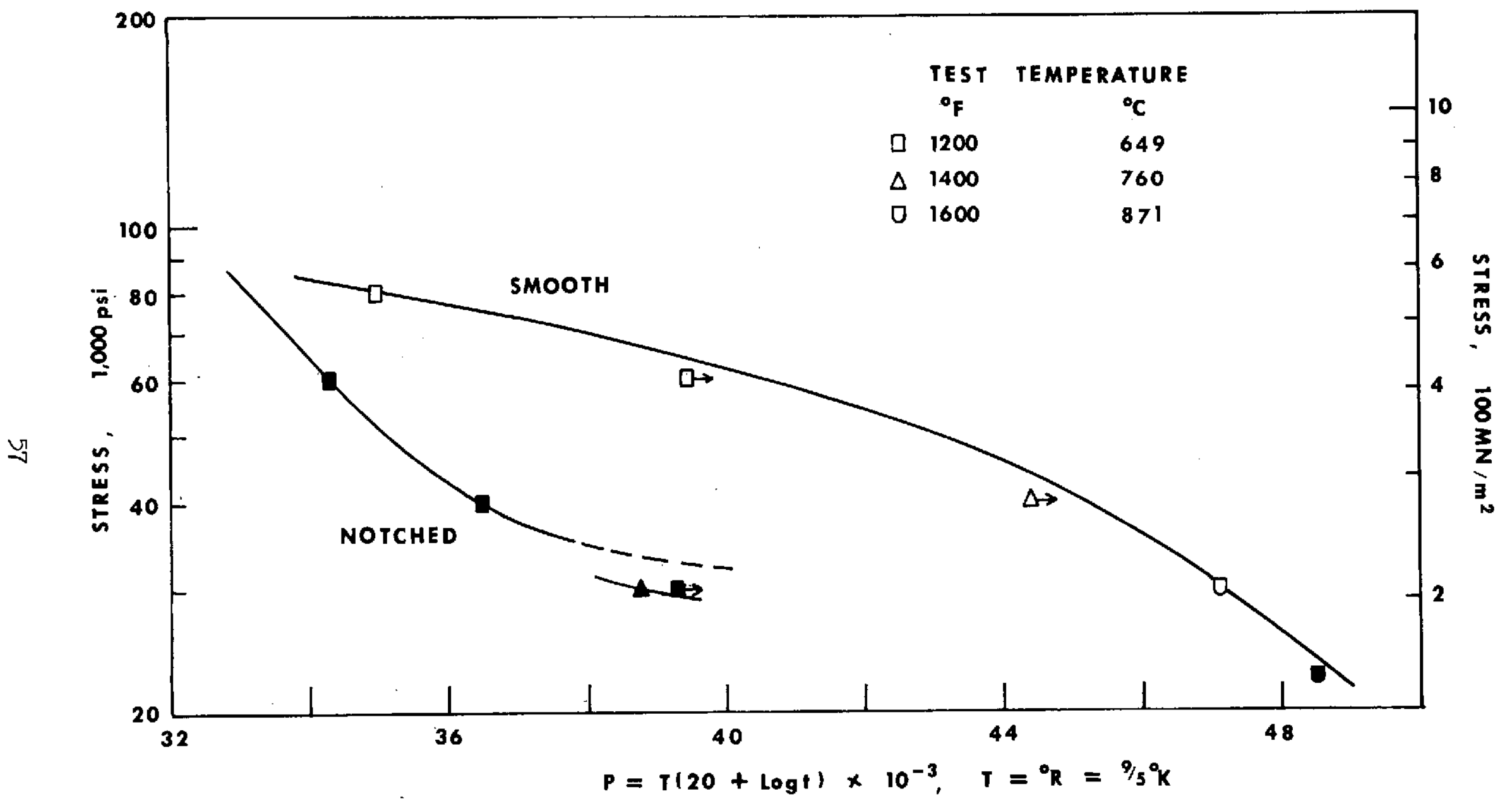

Figure 16. Iarson-Miller parameter curves showing the time-temperature dependence of the rupture strengths of smooth and edge-notched ("flat") specimens of investment-cast Udimet 700 solution treated and aged 3 hours at $1500^{\circ} \mathrm{F}\left(816^{\circ} \mathrm{C}\right)$. Time-dependent notch sensitivity occurred at the lower test temperatures but not at $1600^{\circ} \mathrm{F}\left(871^{\circ} \mathrm{C}\right)$. 


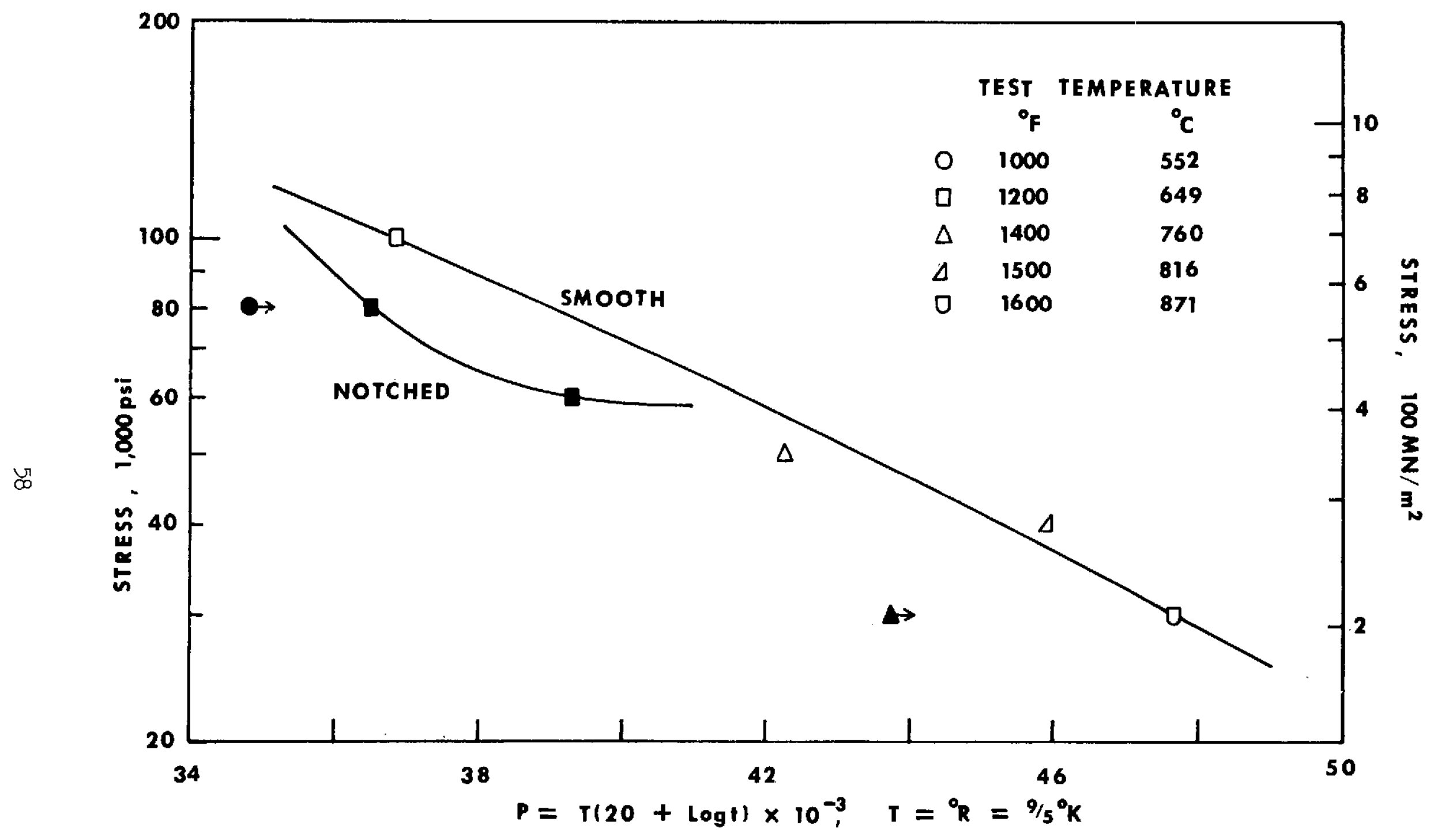

Figure 17. Larson-Miller parameter curves of the rupture strengths of investment-cast Udimet 700 solution treated and aged 4 hours at $1975^{\circ} \mathrm{F}\left(1079^{\circ} \mathrm{C}\right)$ plus 24 hours at $1550^{\circ} \mathrm{F}\left(843^{\circ} \mathrm{C}\right)$ plus 16 hours at $1400^{\circ} \mathrm{F}\left(760^{\circ} \mathrm{C}\right)$. 
TEMPERATURE, ${ }^{\circ} \mathrm{C}$

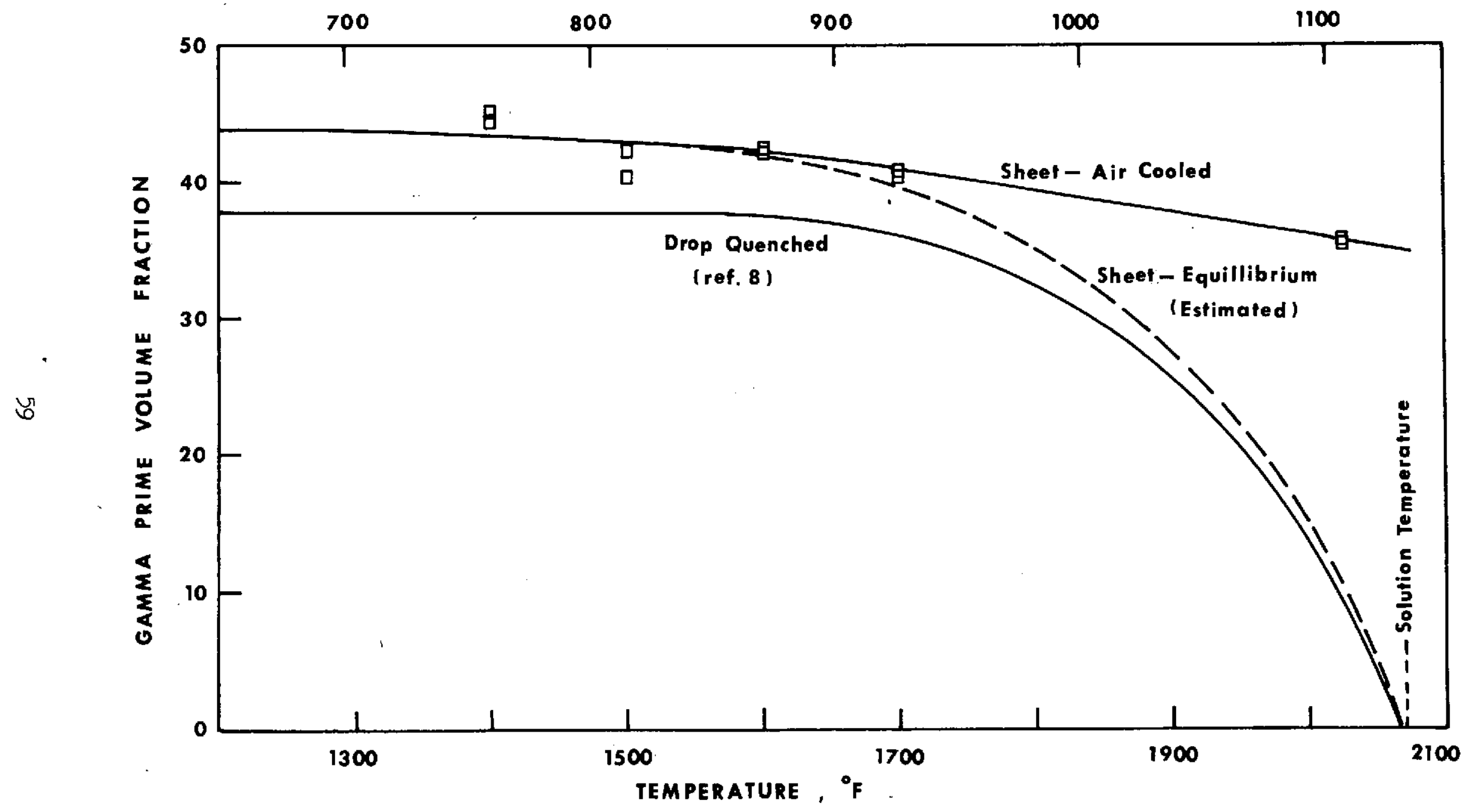

Figure 18. The volume fraction of gamma prime in sheet Udimet 700 as a function of temperature. Air cooled specimens contained higher amounts than the equilibrium values at elevated temperatures due to the precipitation of gamma prime during cooling. 


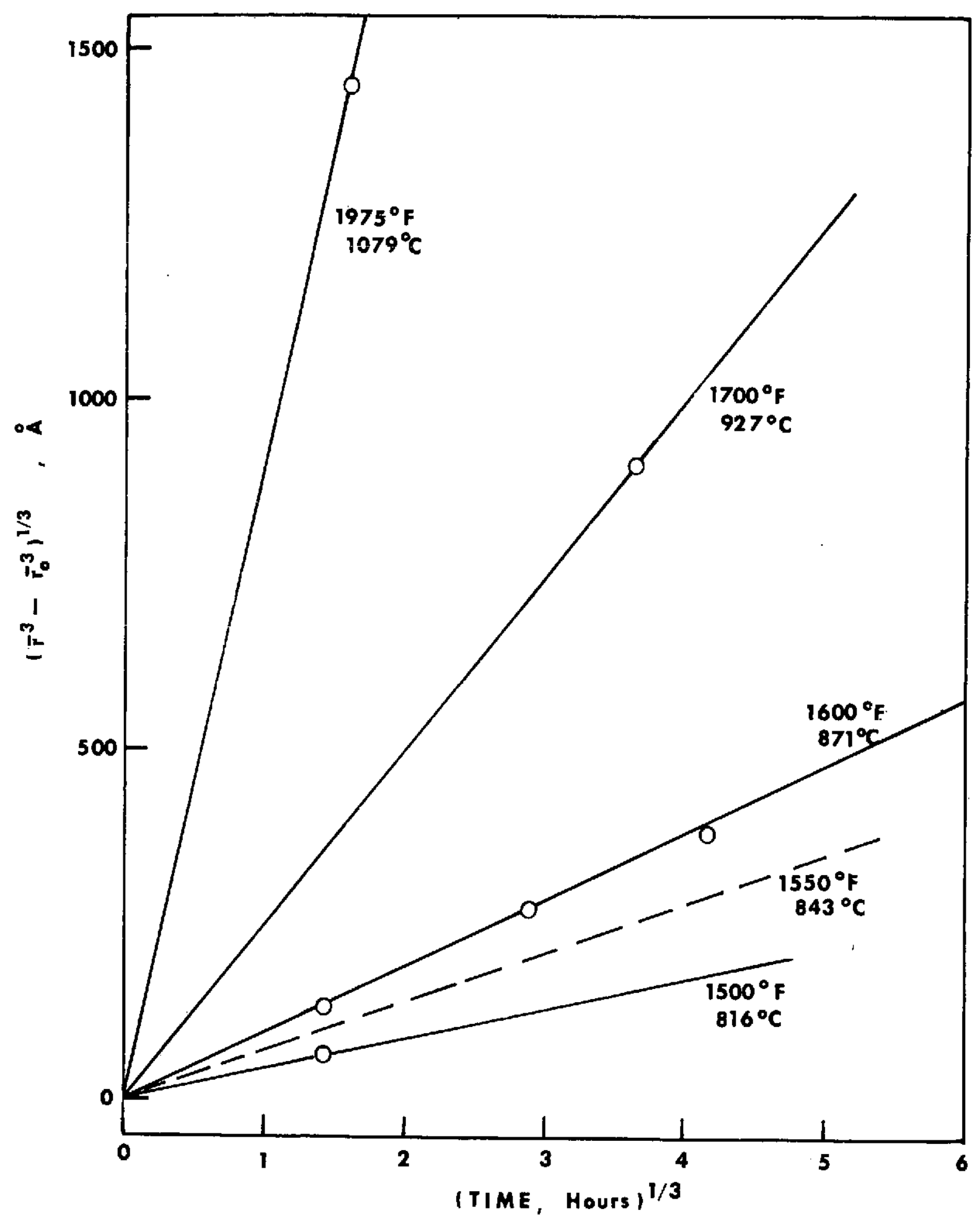

Figure 19. Coarsening of gamma prime in sheet Udimet 700 at elevated temperatures as a function of the cube root of time. At zero time the mean particle size was $100 \AA$ which resulted from air cooling from the solution treatment temperature. The curve gradients are values for the rate constant $k$. 


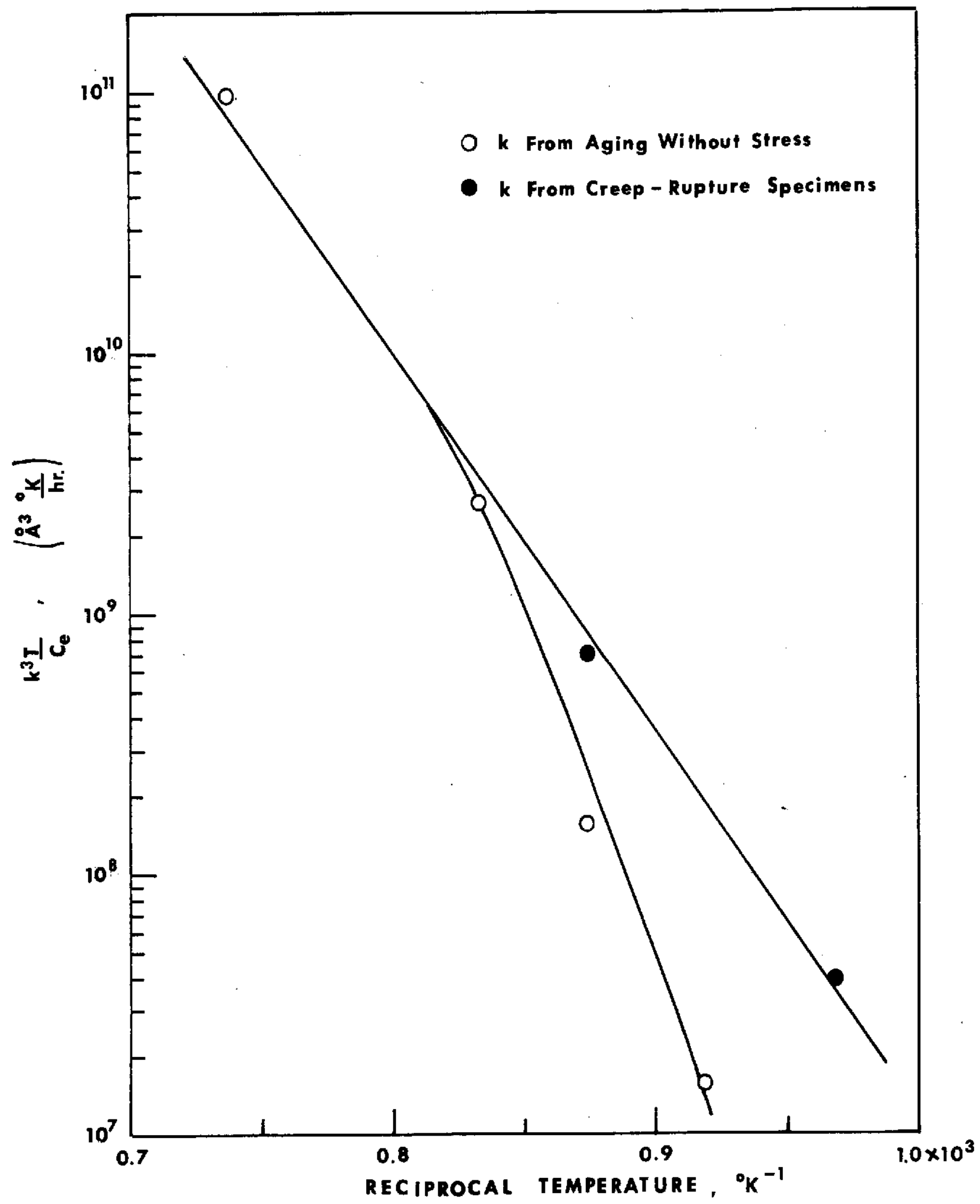

Figure 20. The cube of the rate constant, compensated by the change in concentration of the solute with temperature, as a function of reciprocal temperature. 


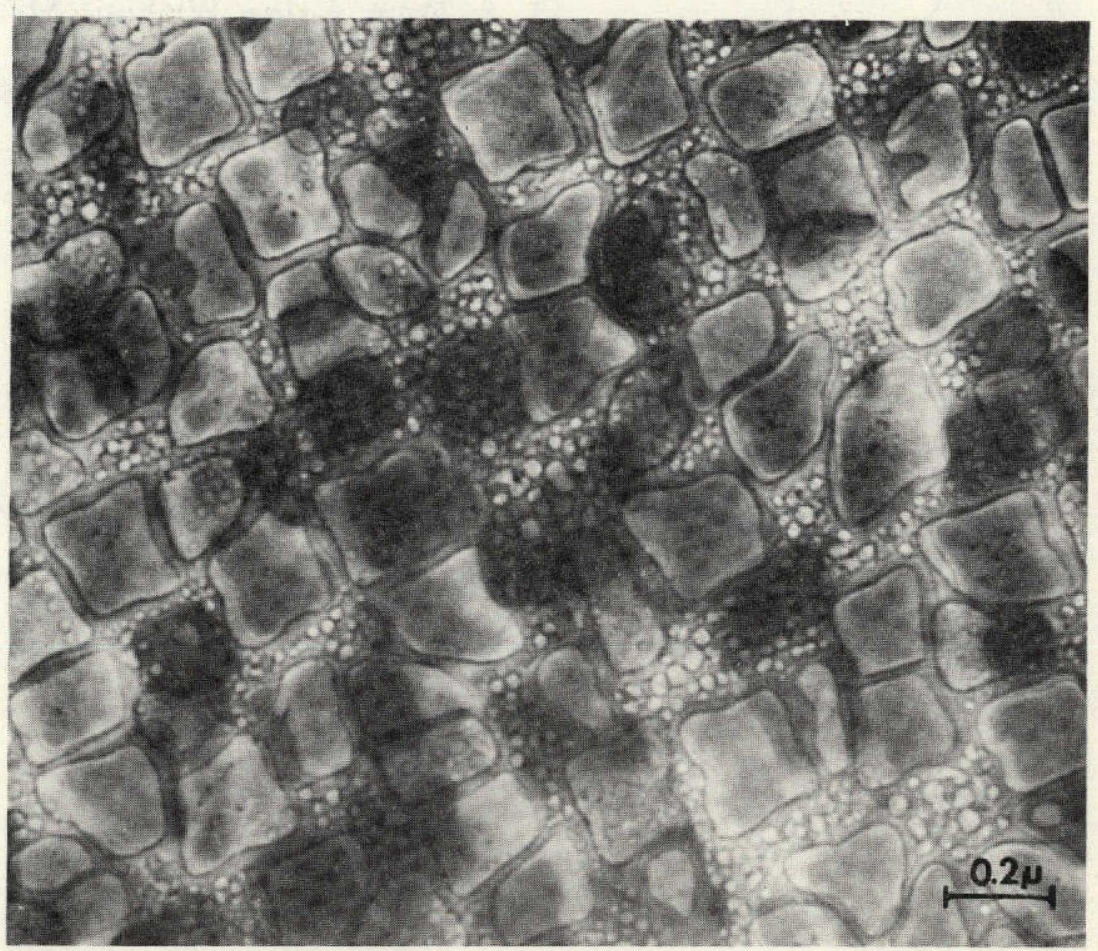

Figure 2l. Transmission electron micrograph of a thin foil of Udimet 700 bar solution treated at $2150^{\circ} \mathrm{F}\left(1177^{\circ} \mathrm{C}\right)$ and aged 3 hours at $1500^{\circ} \mathrm{F}\left(816^{\circ} \mathrm{C}\right)$. The large gamma prime particles formed during air cooling from the solution treatment temperature and then coarsened further during aging. The fine particles developed during aging. 


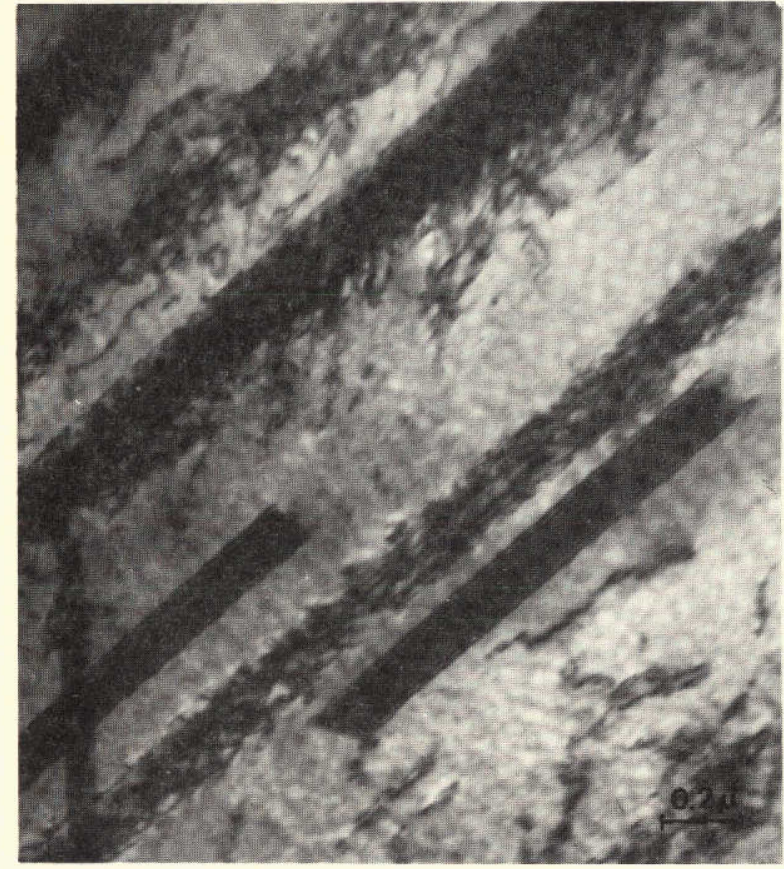

(a)

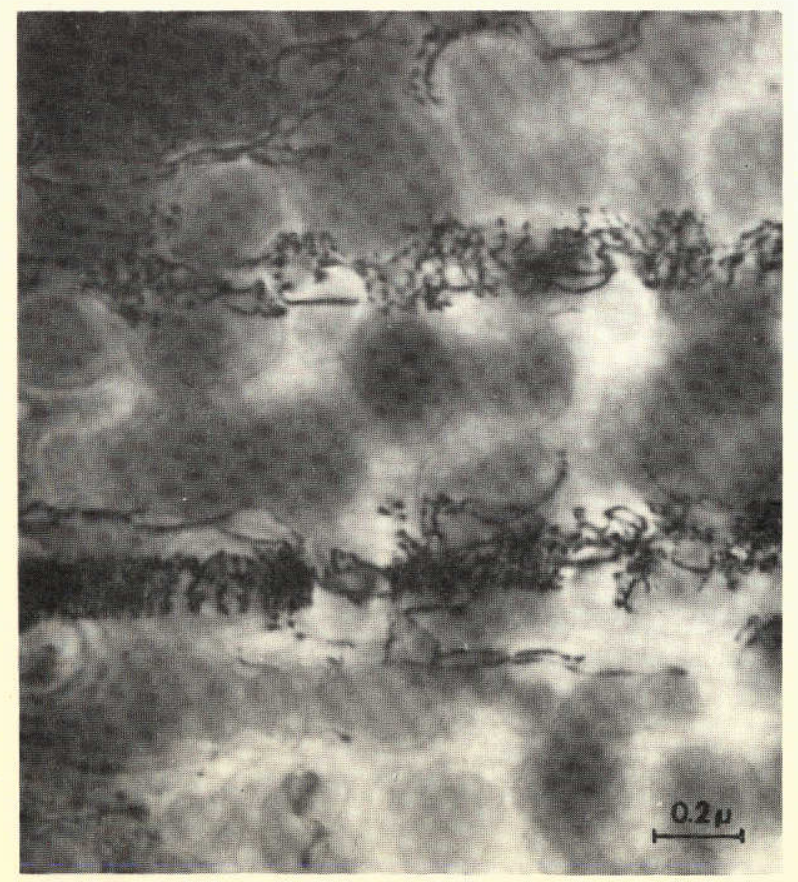

(c)

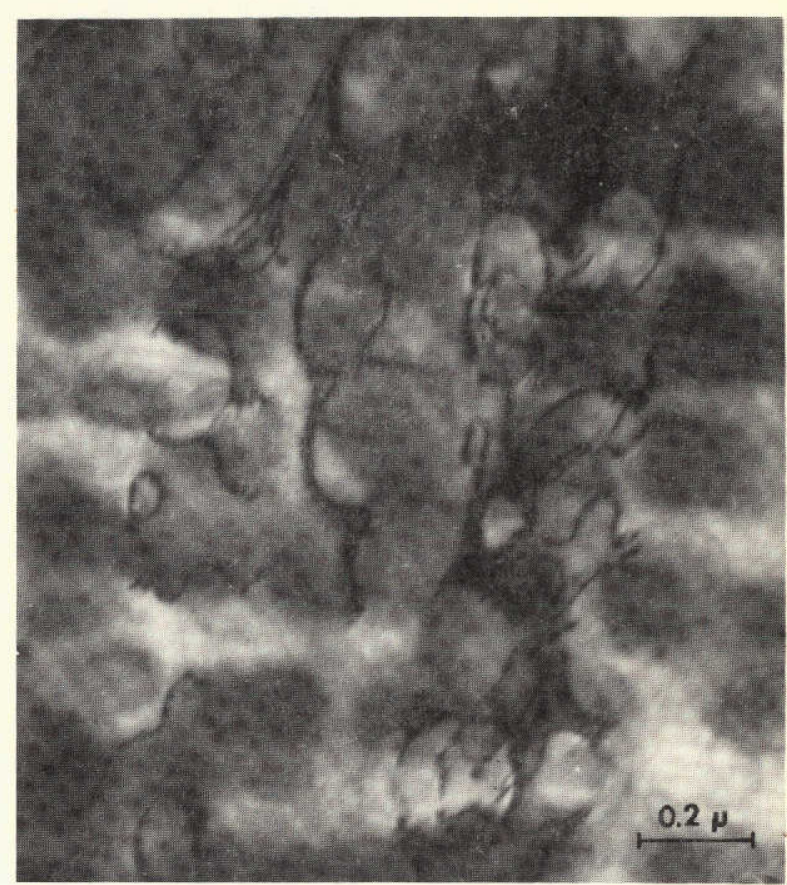

(b)

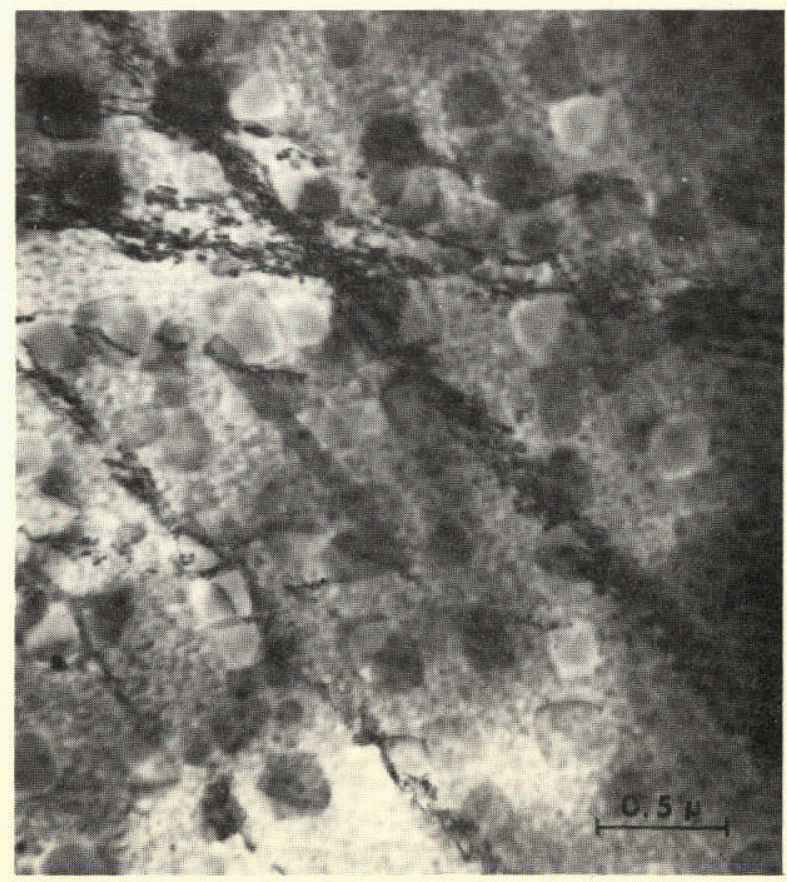

(d)

Figure 22. Transmission electron micrographs of thin foils taken from the gauge sections of smooth specimens of sheet Udimet 700 solution treated, aged, and tensile tested at $1200^{\circ} \mathrm{F}\left(649^{\circ} \mathrm{C}\right)$. Aging treatments: (a) 3 hours at $1500^{\circ} \mathrm{F}\left(816^{\circ} \mathrm{C}\right),(\mathrm{b})$ and (c) 48 hours at $1700^{\circ} \mathrm{F}\left(927^{\circ} \mathrm{C}\right)$, and (d) "multiple" treatment. 


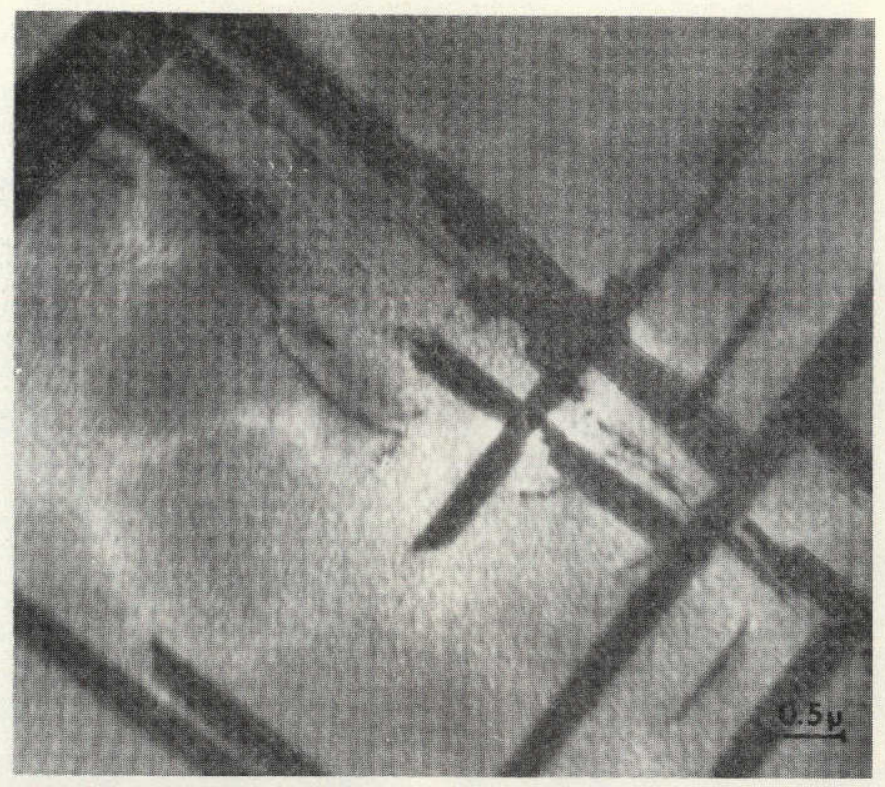

(a)

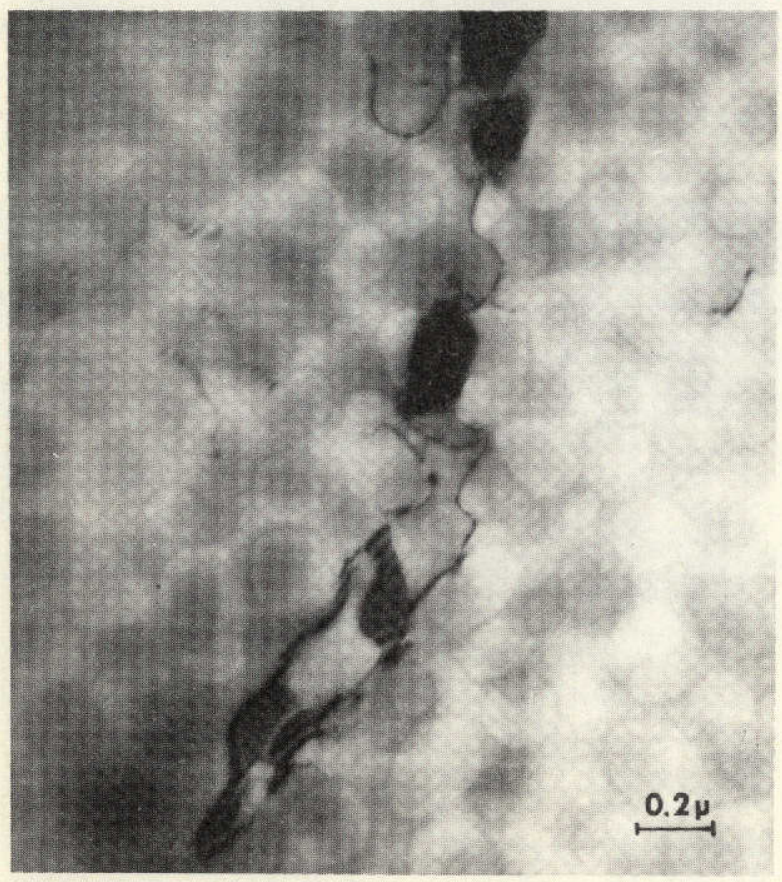

(b)

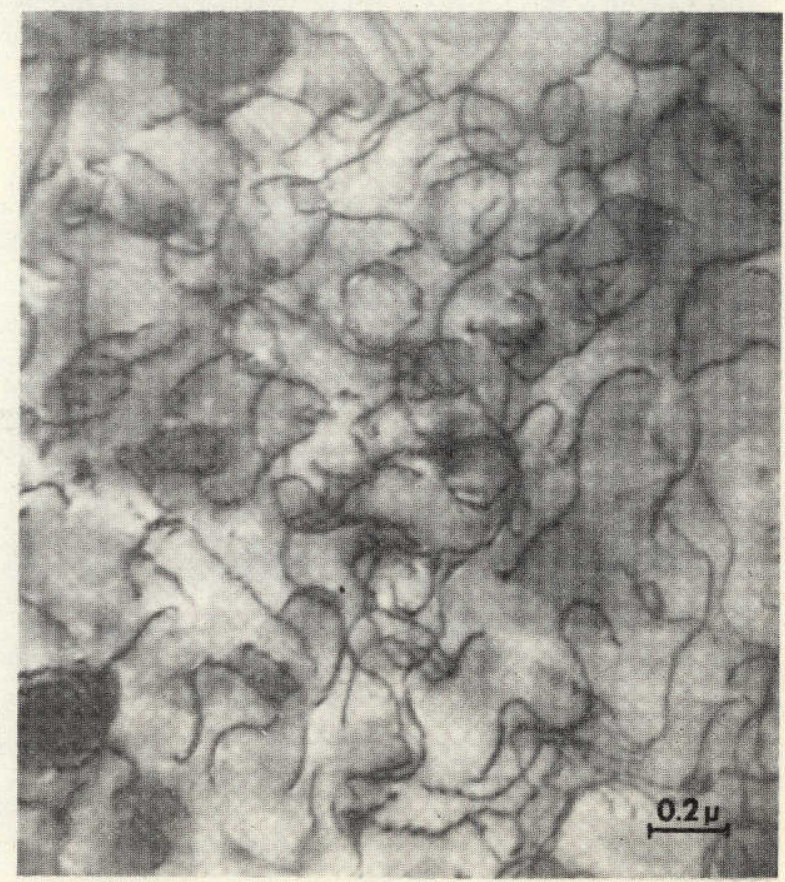

(c)

Figure 23. Thin foil electron micrographs of smooth specimens of sheet Udimet 700 solution treated, aged 3 hours at $1500^{\circ} \mathrm{F}\left(816^{\circ} \mathrm{C}\right)$ and creep-rupture tested. (a) Tested at $1000^{\circ} \mathrm{F}\left(538^{\circ} \mathrm{C}\right)$ at $110 \mathrm{ksi}\left(758 \mathrm{MV} / \mathrm{m}^{2}\right)$. (b) Tested at $1400^{\circ} \mathrm{F}$ $\left(760^{\circ} \mathrm{C}\right.$ ) at $35 \mathrm{ksi}\left(241 \mathrm{MN} / \mathrm{m}^{2}\right)$. (c) Tested at $1600^{\circ} \mathrm{F}\left(871^{\circ} \mathrm{C}\right)$ at $30 \mathrm{ksi}(207$ $\left.\mathrm{MN} / \mathrm{m}^{2}\right)$. 


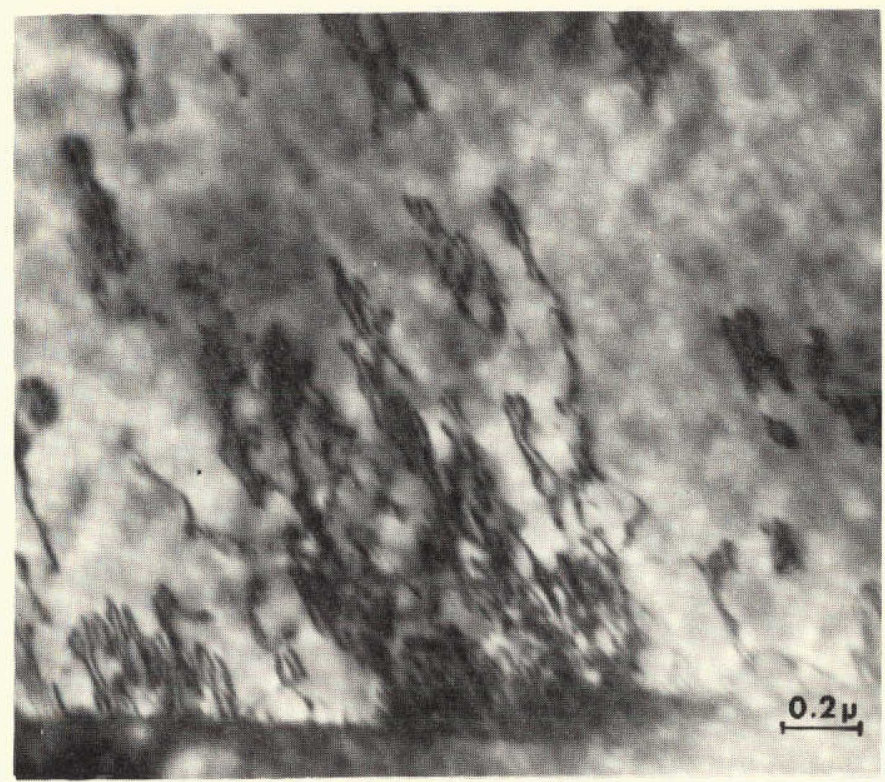

(a)

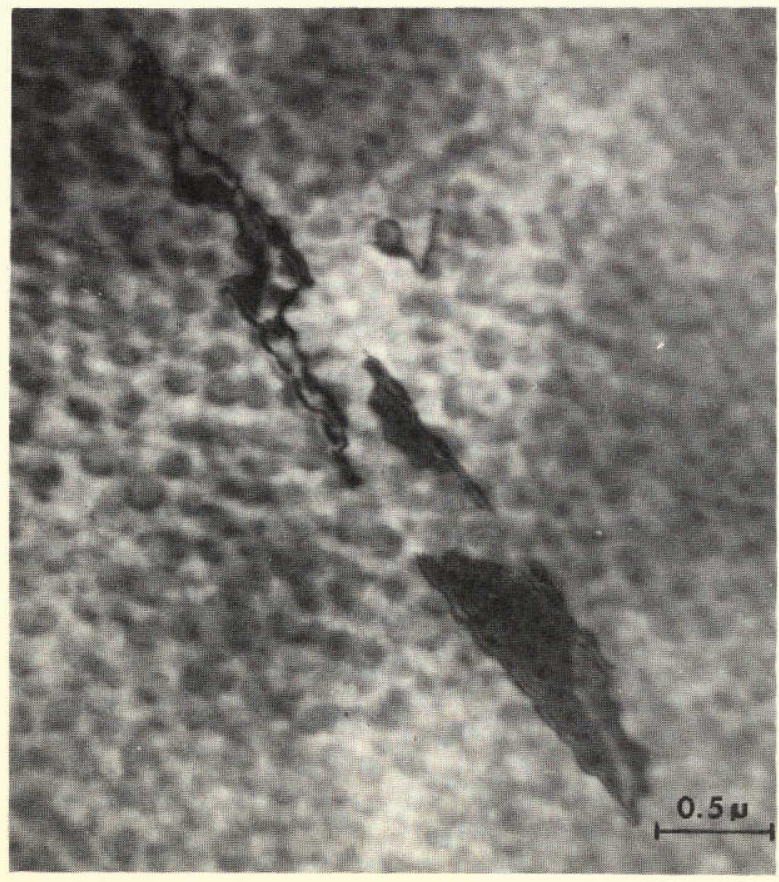

(b)

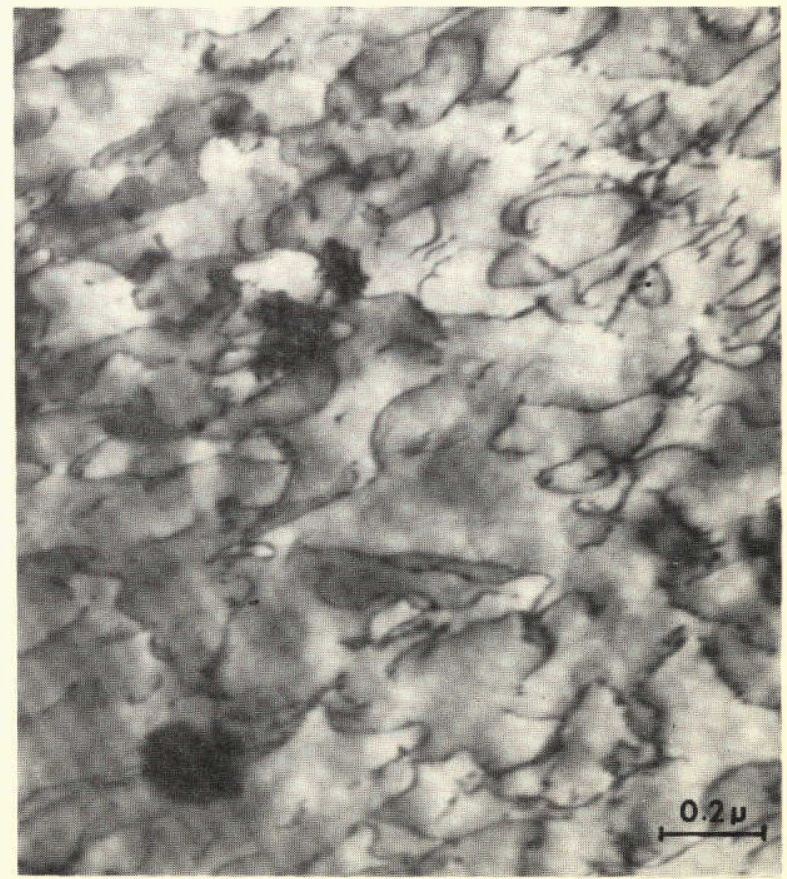

(c)

Figure 24. Transmission electron micrographs of thin foils of smooth specimens of sheet Udimet 700 solution treated, aged 24 hours at $1600^{\circ} \mathrm{F}\left(871^{\circ} \mathrm{C}\right)$ and creep-rupture tested. (a) Tested at $1000^{\circ} \mathrm{F}\left(538^{\circ} \mathrm{C}\right)$ at $120 \mathrm{ksi}\left(827 \mathrm{MN} / \mathrm{m}^{2}\right)$. (b) Tested at $1200^{\circ} \mathrm{F}\left(649^{\circ} \mathrm{C}\right.$ ) at $90 \mathrm{ksi}\left(620 \mathrm{MN} / \mathrm{m}^{2}\right)$. (c) Tested at $1400^{\circ} \mathrm{F}$ $\left(760^{\circ} \mathrm{C}\right)$ at $50 \mathrm{ksi}\left(345 \mathrm{MN} / \mathrm{m}^{2}\right)$. 


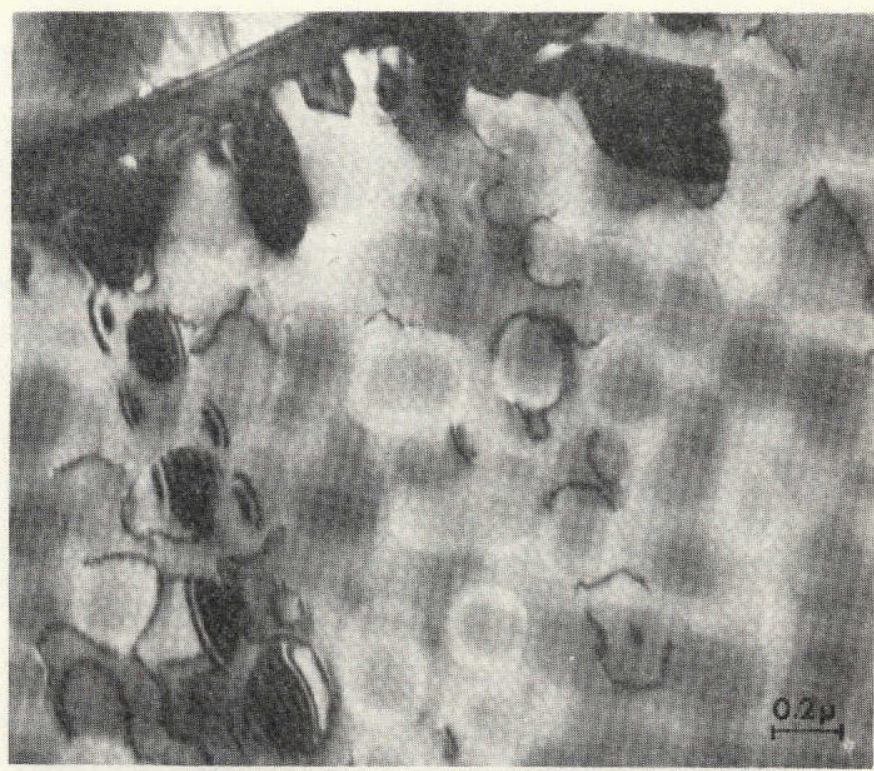

(a)

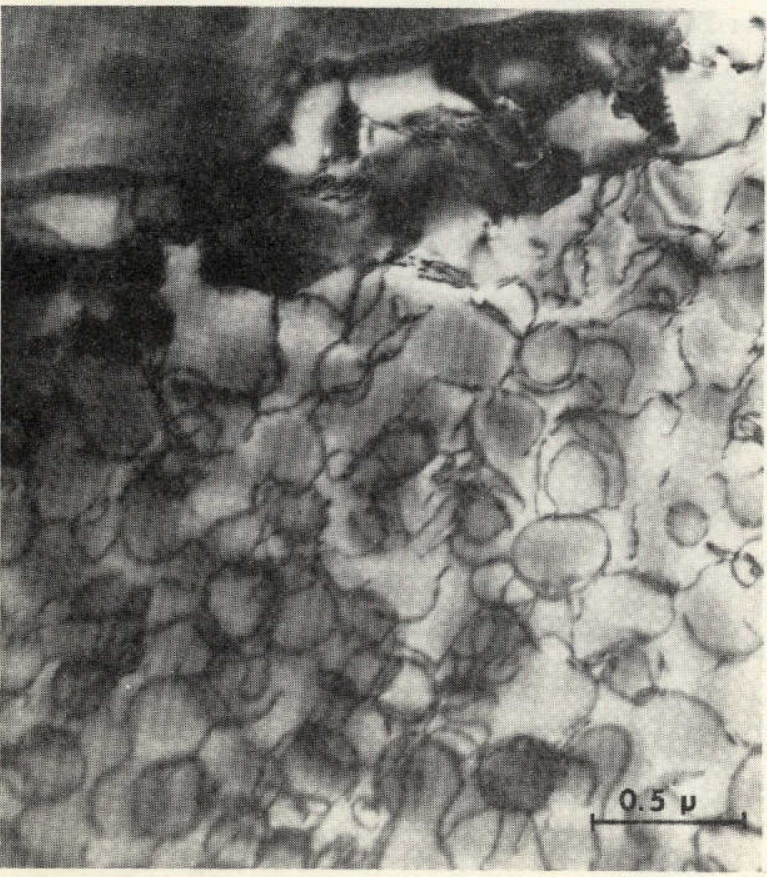

(b)

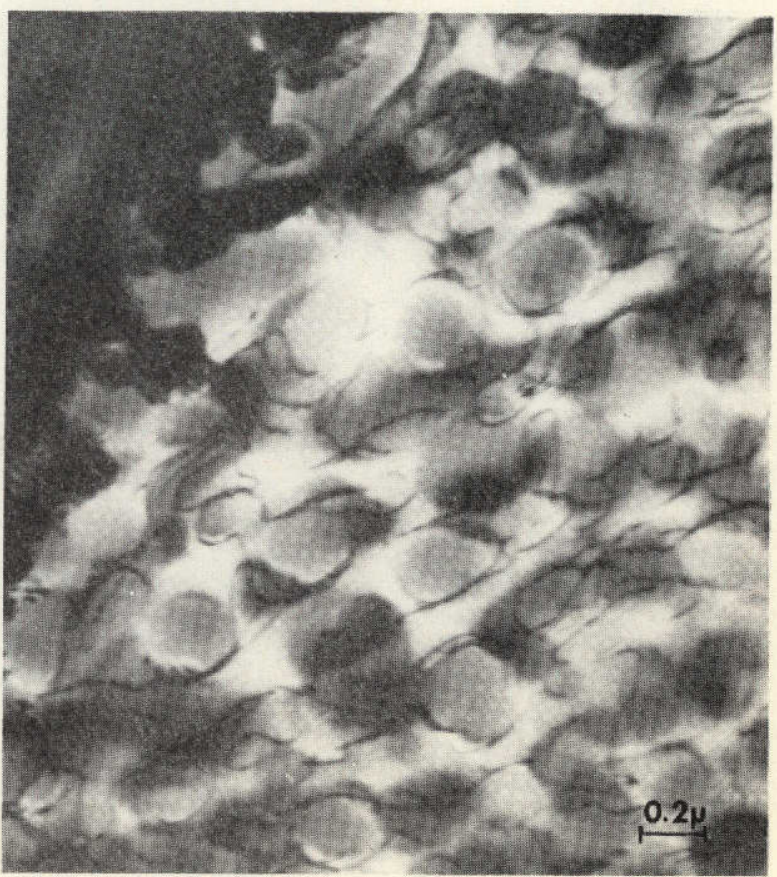

(c)

Figure 25. Thin foil electron micrographs of smooth specimens of sheet Udimet 700 solution treated, aged 48 hours at $1700^{\circ} \mathrm{F}\left(927^{\circ} \mathrm{C}\right)$ and creep-rupture tested. (a) Tested at $1200^{\circ} \mathrm{F}\left(649^{\circ} \mathrm{C}\right)$ at $90 \mathrm{ksi}\left(620 \mathrm{MN} / \mathrm{m}^{2}\right)$.

(b) Tested at $1400^{\circ} \mathrm{F}$ $\left(760^{\circ} \mathrm{C}\right)$ at $50 \mathrm{ksi}\left(345 \mathrm{MN} / \mathrm{m}^{2}\right)$. (c) Tested at $1600^{\circ} \mathrm{F}\left(871^{\circ} \mathrm{C}\right)$ at $30 \mathrm{ksi}(207$ $\left.\mathrm{MN} / \mathrm{m}^{2}\right)$. 


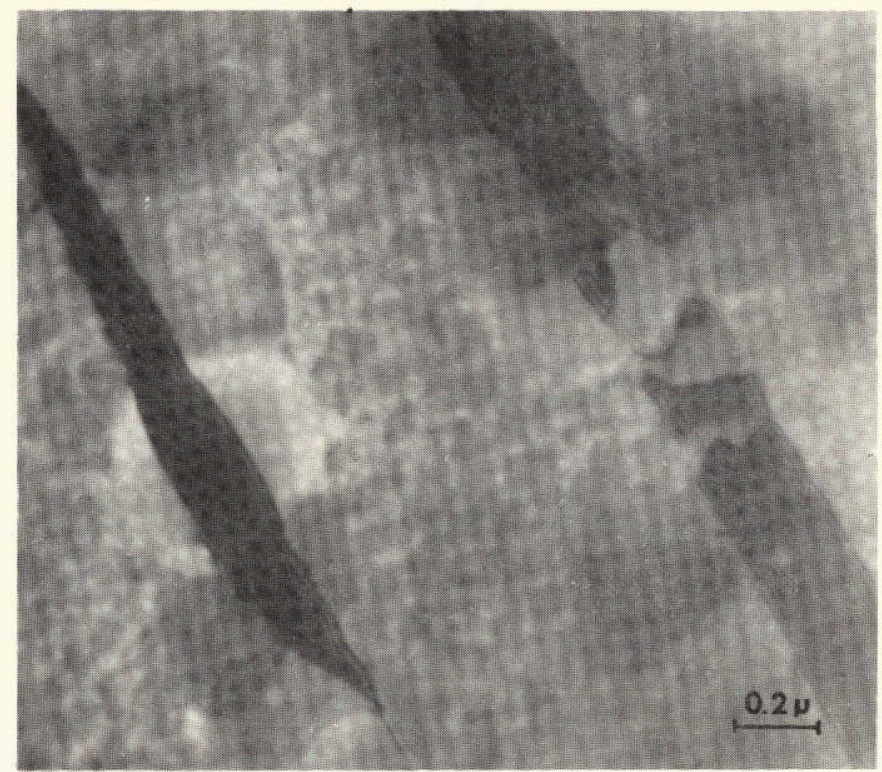

(a)

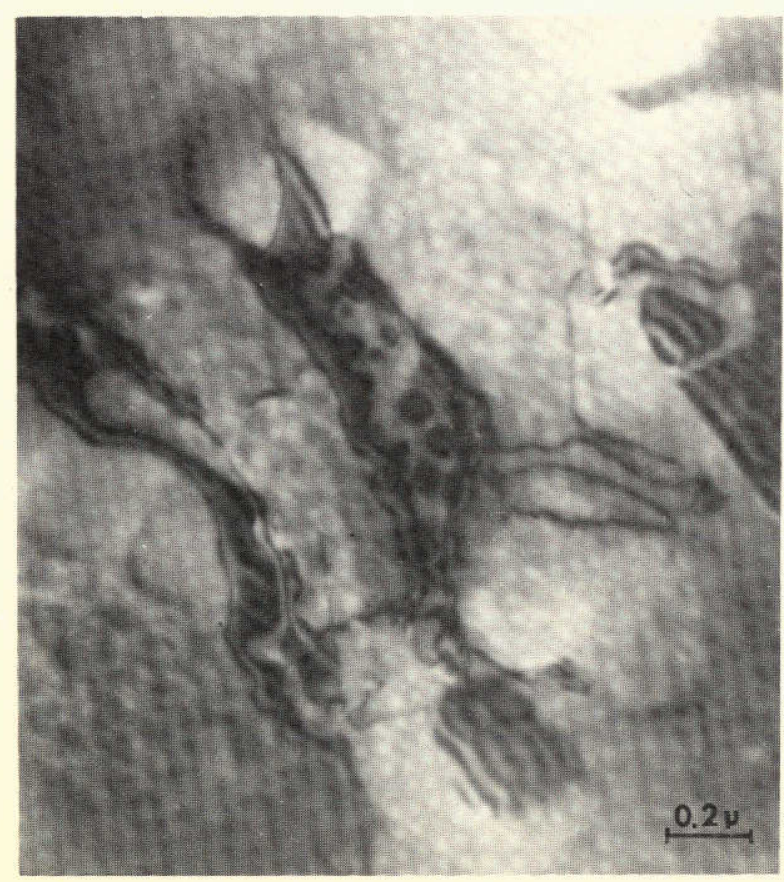

(b)

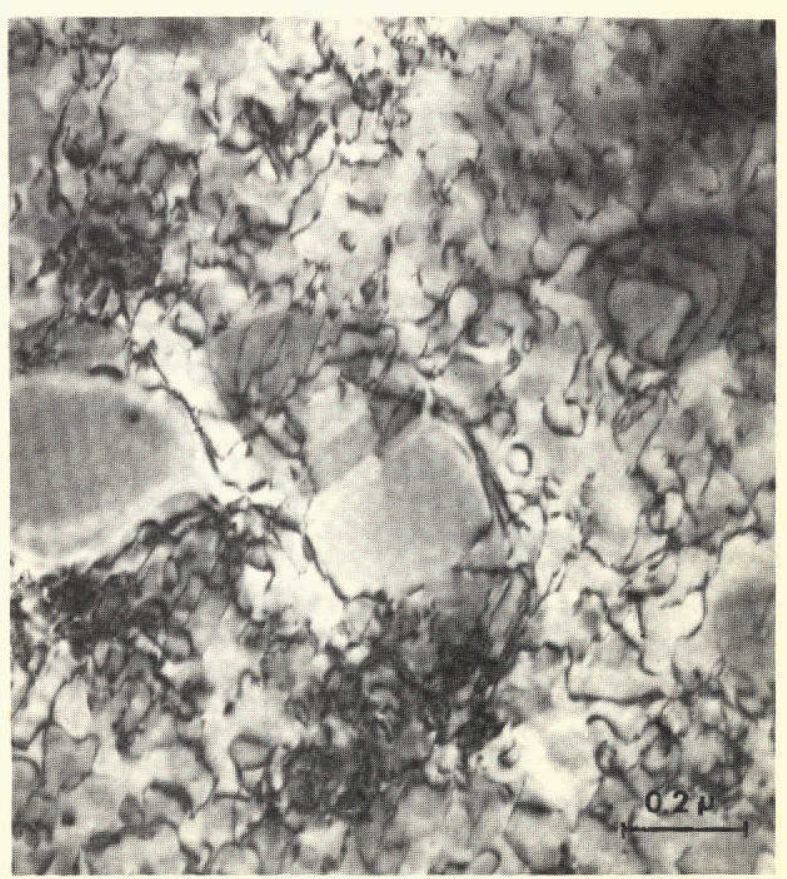

(c)

Figure 26. Transmission electron micrographs of thin foils of smooth specimens of sheet Udimet 700 solution treated, aged 4 hours at $1975^{\circ} \mathrm{F}\left(1079^{\circ} \mathrm{C}\right.$ ) plus 24 hours at $1550^{\circ} \mathrm{F}\left(843^{\circ} \mathrm{C}\right)$ plus 16 hours at $1400^{\circ} \mathrm{F}\left(760^{\circ} \mathrm{C}\right)$ and creeprupture tested. Test conditions: (a) and (b) $1200^{\circ} \mathrm{F}\left(649^{\circ} \mathrm{C}\right.$ ) at $120 \mathrm{ksi}(827$ $\left.\mathrm{MN} / \mathrm{m}^{2}\right)$, (c) and (d) $1400^{\circ} \mathrm{F}\left(760^{\circ} \mathrm{C}\right.$ ) at $70 \mathrm{ksi}\left(483 \mathrm{MN} / \mathrm{m}^{2}\right)$, (e) $1600^{\circ} \mathrm{F}\left(871^{\circ} \mathrm{C}\right)$ at $30 \mathrm{ksi}\left(207 \mathrm{MN} / \mathrm{m}^{2}\right)$, and $(\mathrm{f}) 1600^{\circ} \mathrm{F}\left(871^{\circ} \mathrm{C}\right)$ at $20 \mathrm{ksi}\left(139 \mathrm{MV} / \mathrm{m}^{2}\right)$. 


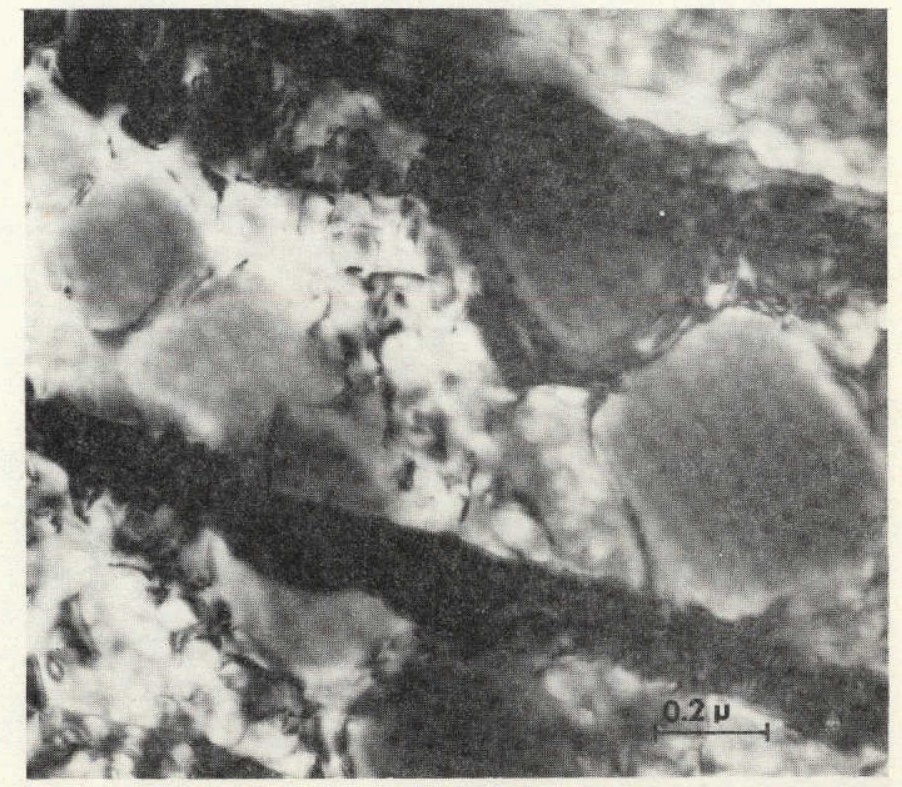

(a)

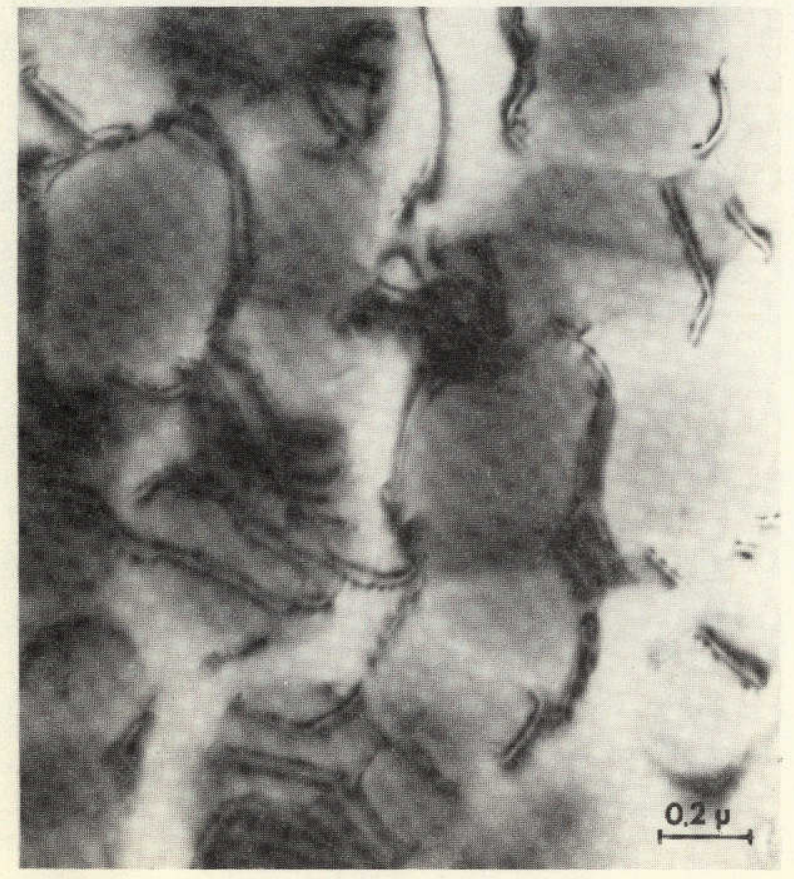

(e)

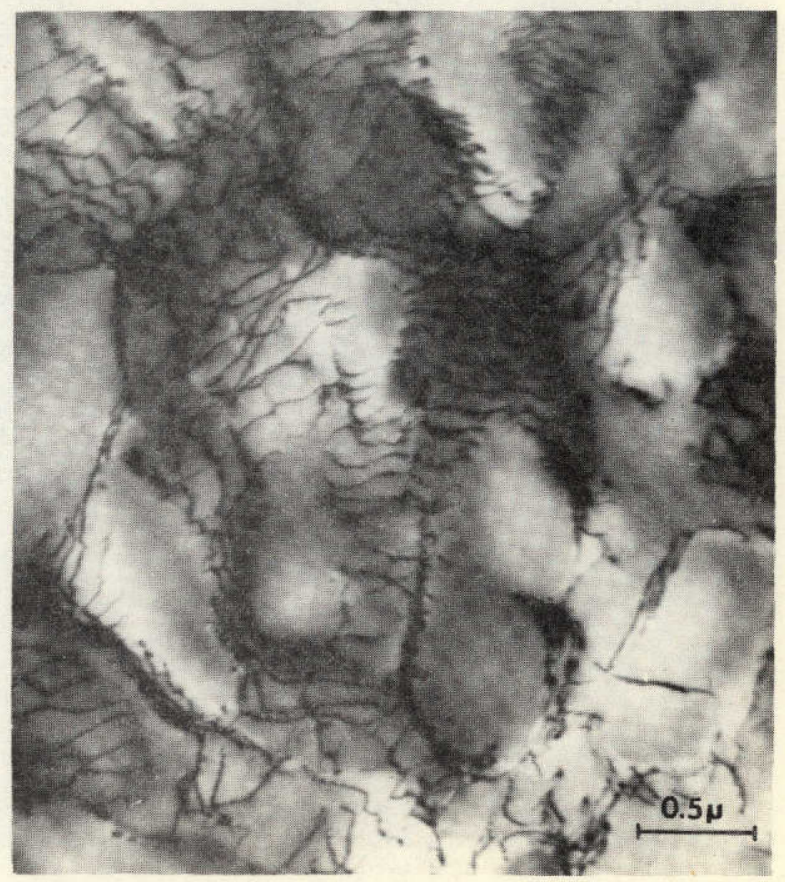

(f)

Figure 26. (Concluded) 


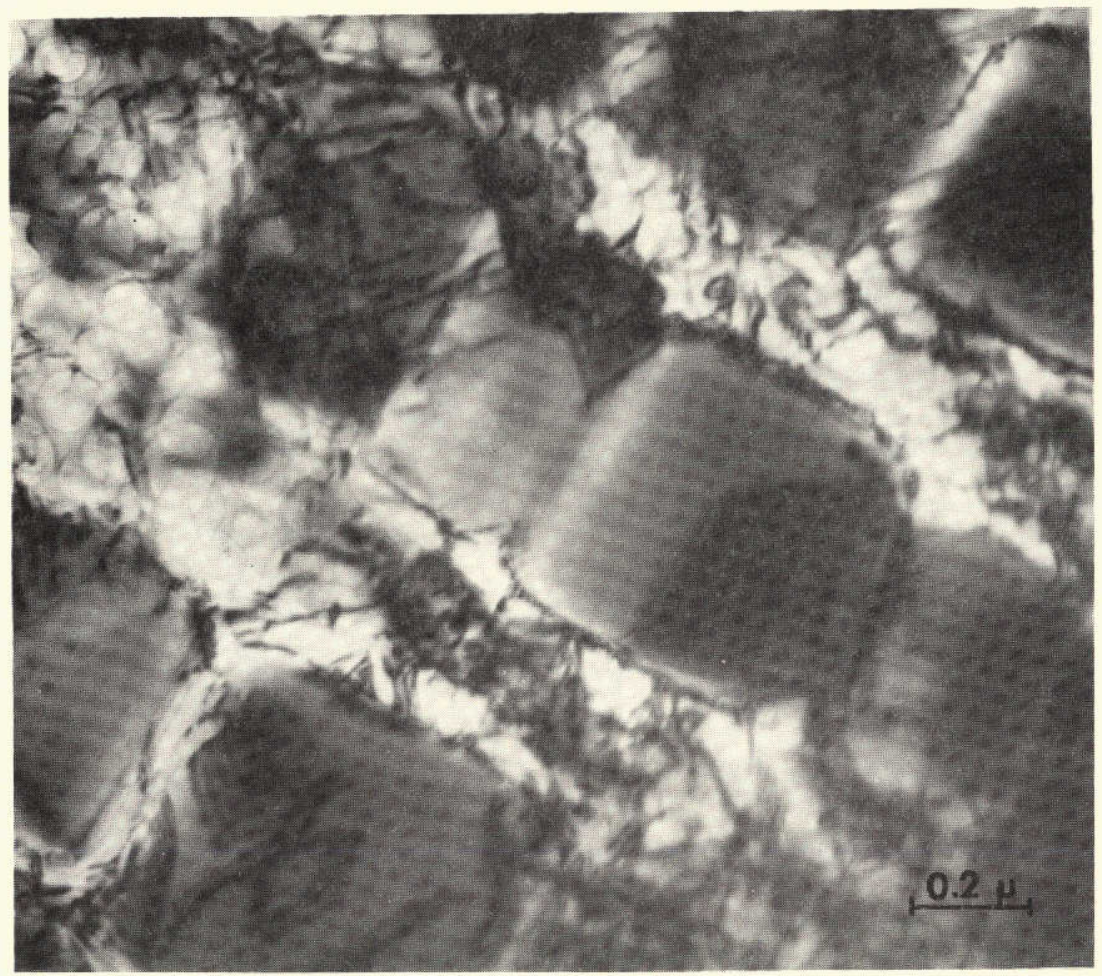

Figure 27. Thin foil electron micrograph of a smooth specimen of Udimet 700 bar solution treated, aged 4 hours at $1975^{\circ} \mathrm{F}$ (1079 $\mathrm{C}$ ) plus 24 hours at $1550^{\circ} \mathrm{F}$ $\left(843^{\circ} \mathrm{C}\right)$ plus 16 hours at $1400^{\circ} \mathrm{F}\left(760^{\circ} \mathrm{C}\right)$ and creep-rupture tested at $1200^{\circ} \mathrm{F}$ $\left(649^{\circ} \mathrm{C}\right)$ at $110 \mathrm{ksi}\left(758 \mathrm{MN} / \mathrm{m}^{2}\right)$. 


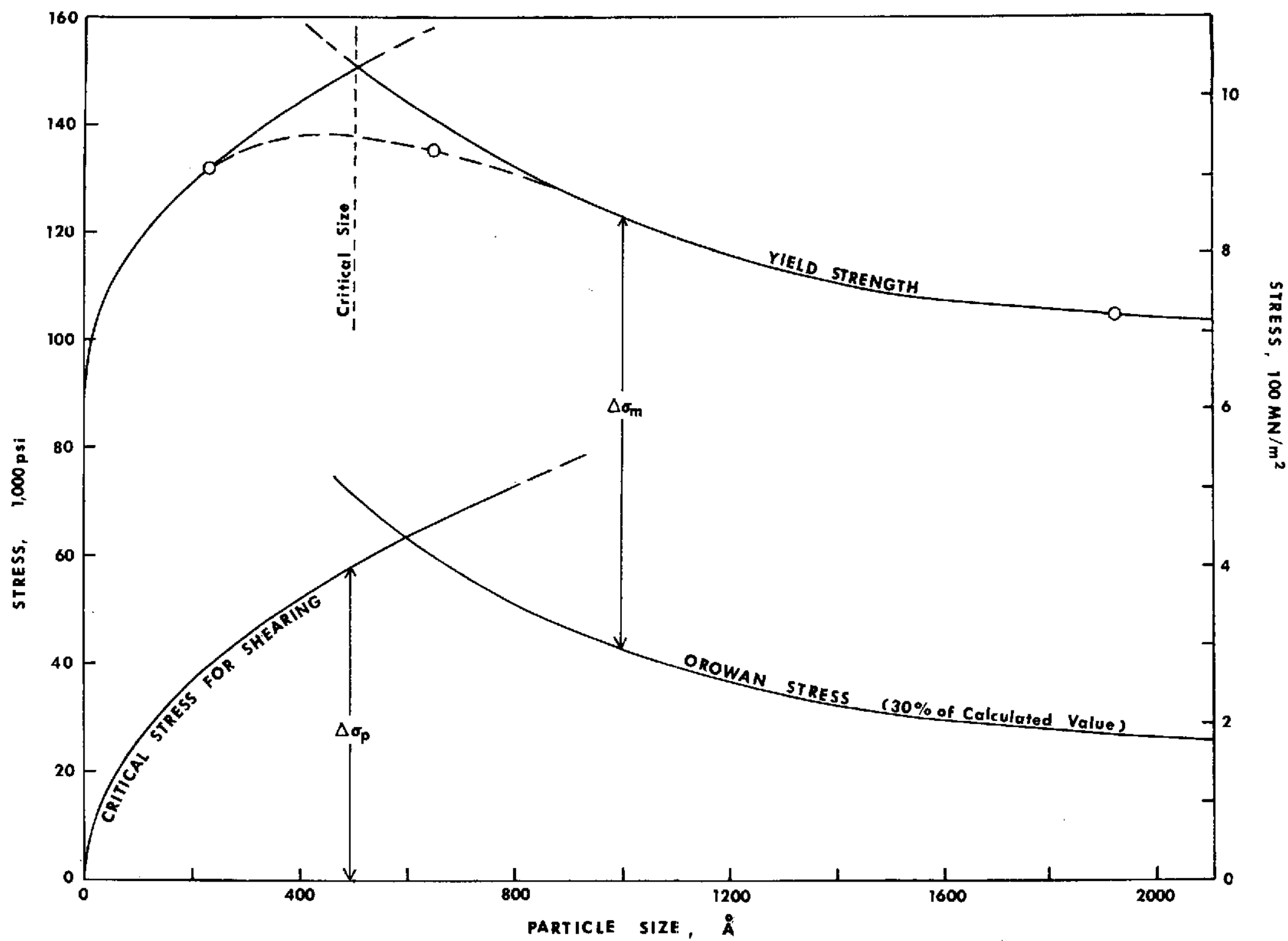

Figure 28. The variation of the yield strength at $1200^{\circ} \mathrm{F}\left(649^{\circ} \mathrm{C}\right)$ of sheet Udimet 700 witn tne gamma prime particle size. The yield strength of the alloy can be determined by adding the yield strength of the matrix $\left(\Delta \sigma_{\mathrm{m}}\right)$ to the increase in strength due to the particles $\left(\Delta \sigma_{\mathrm{p}}\right)$. 


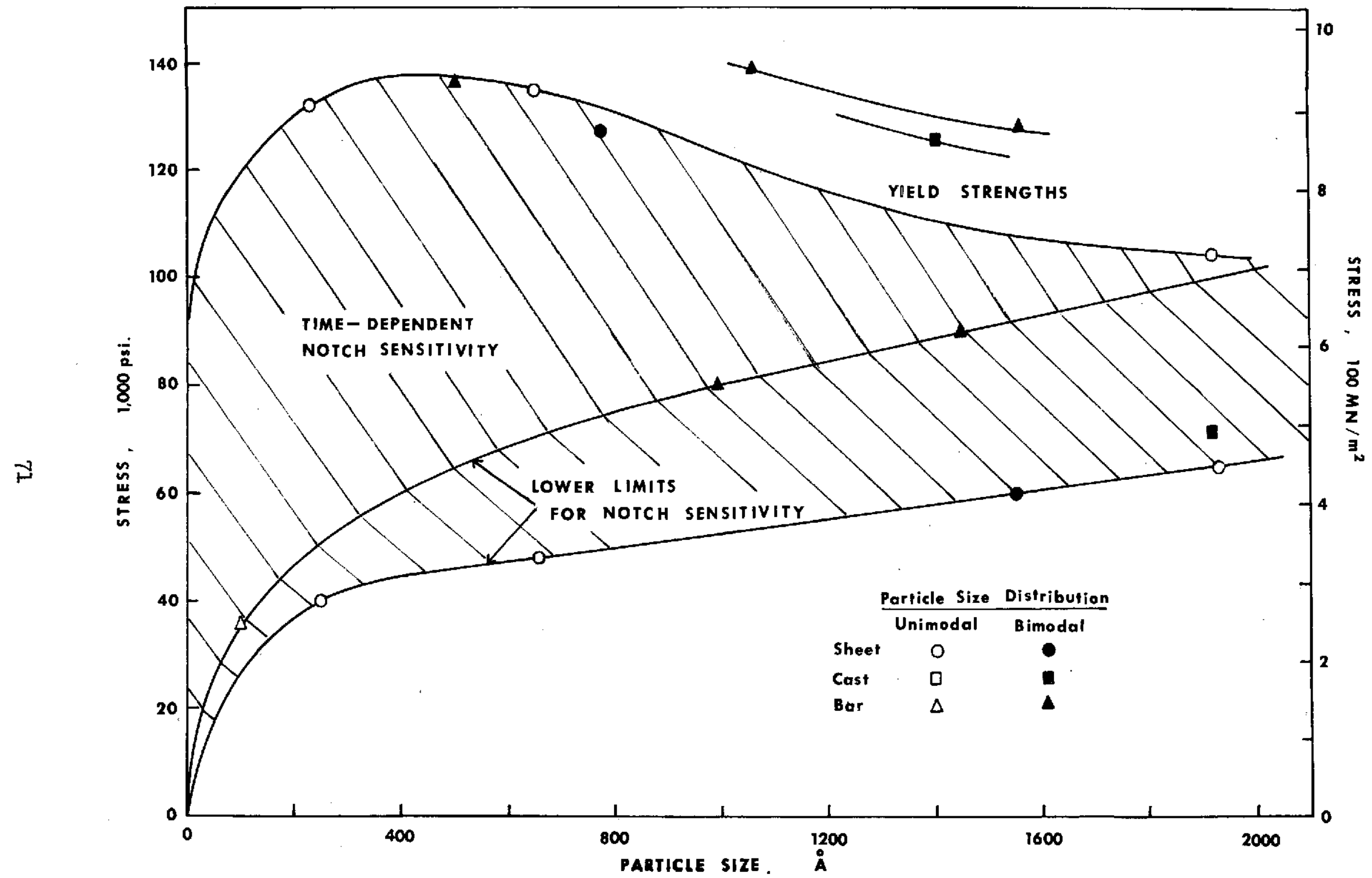

Figure 29. The dependence of the time-dependent notch sensitivity at $1200^{\circ} \mathrm{F}\left(649^{\circ} \mathrm{C}\right)$ of Udimet 700 sheet, bar and investment castings on the test stress and the gamma prime particle size. Time-dependent notch sensitivity occurs when notched specimens were loaded below the yield strength and when dislocations-sheared the gamma prime particles. 


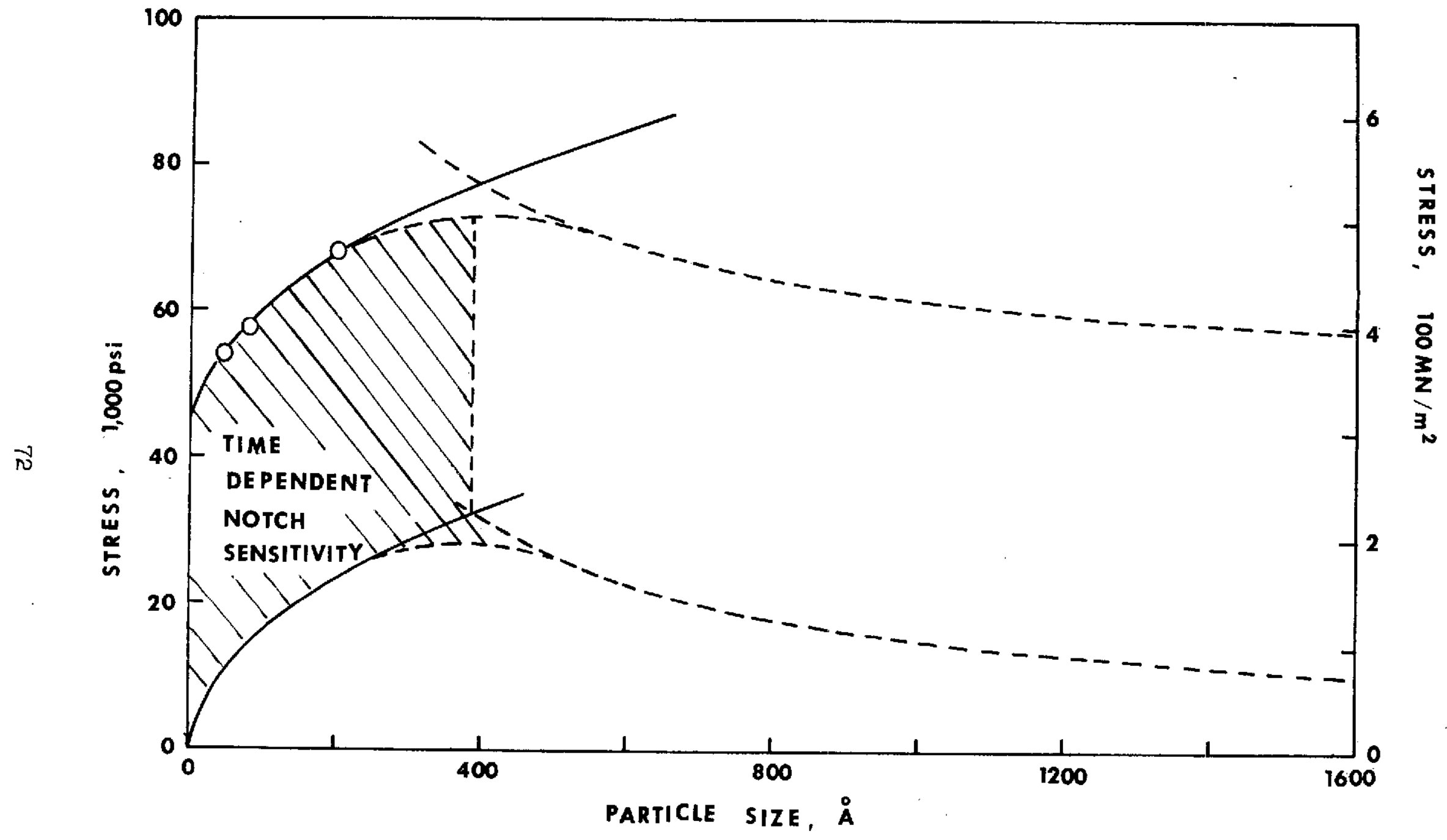

Figure 30. The dependence of the time-dependent notch sensitivity at $1000^{\circ} \mathrm{F}\left(538^{\circ} \mathrm{C}\right)$ of Modified Waspaloy sheet on the test stress and gamma prime particle size. 


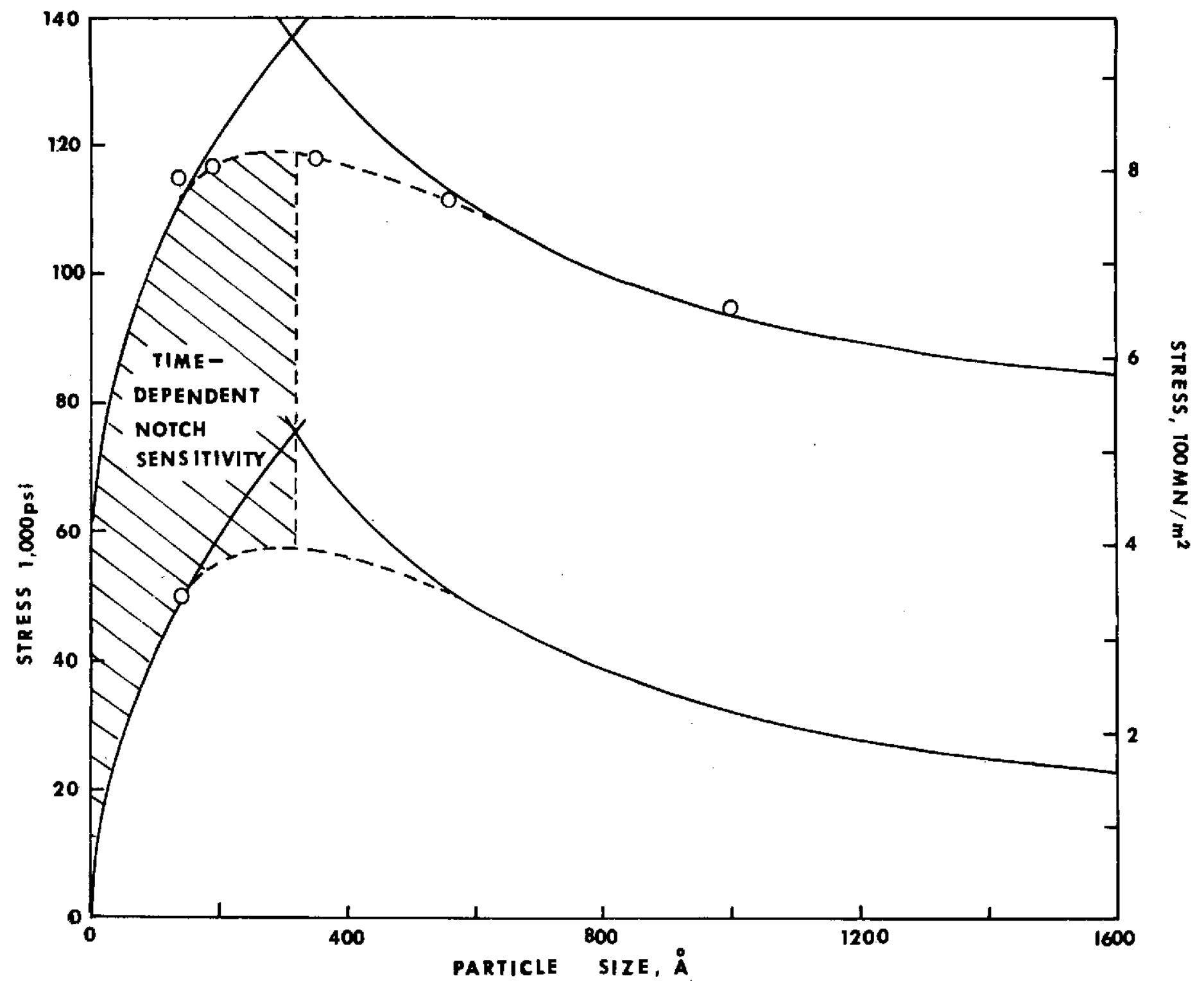

Figure 31. The dependence of the time-dependent notch sensitivity at $1000^{\circ} \mathrm{F}\left(538^{\circ} \mathrm{C}\right)$ of Waspaloy sheet on the test stress and gamma prime particle size. 